\title{
Research and Development Technology Development Roadmaps for the Next Generation Nuclear Plant Project
}

The INL is a

U.S. Department of Energy

National Laboratory

operated by

Battelle Energy Alliance

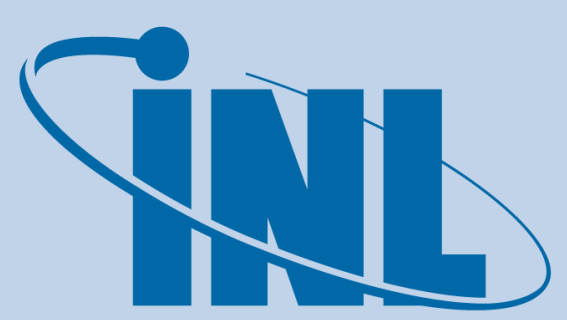

Idaho National Laboratory
July 2011

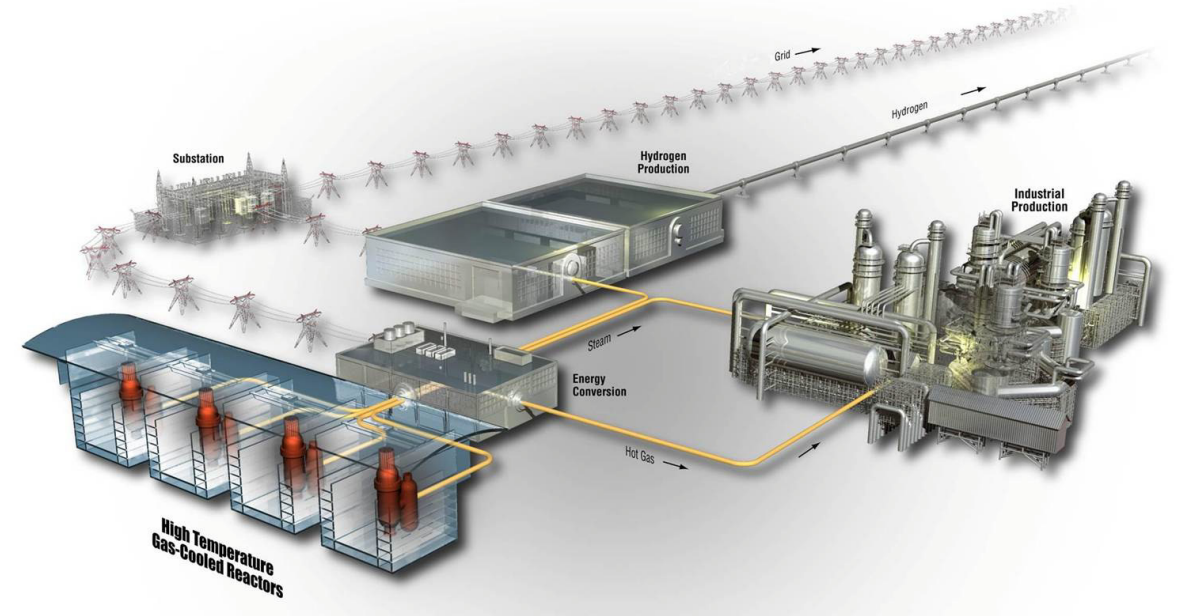




\section{DISCLAIMER}

This information was prepared as an account of work sponsored by an agency of the U.S. Government. Neither the U.S. Government nor any agency thereof, nor any of their employees, makes any warranty, expressed or implied, or assumes any legal liability or responsibility for the accuracy, completeness, or usefulness, of any information, apparatus, product, or process disclosed, or represents that its use would not infringe privately owned rights. References herein to any specific commercial product, process, or service by trade name, trade mark, manufacturer, or otherwise, does not necessarily constitute or imply its endorsement, recommendation, or favoring by the U.S. Government or any agency thereof. The views and opinions of authors expressed herein do not necessarily state or reflect those of the U.S. Government or any agency thereof. 


\section{Research and Development Technology Development Roadmaps for the Next Generation Nuclear Plant Project}

July 2011

Idaho National Laboratory

Next Generation Nuclear Plant Project

Idaho Falls, Idaho 83415

Prepared for the

U.S. Department of Energy

Office of Nuclear Energy

Under DOE Idaho Operations Office

Contract DE-AC07-05ID14517 
This page intentionally left blank. 
Next Generation Nuclear Plant Project

\section{Research and Development Technology Development Roadmaps for the Next Generation Nuclear Plant Project}

INL/EXT-11-22512

July 2011

Approved by:
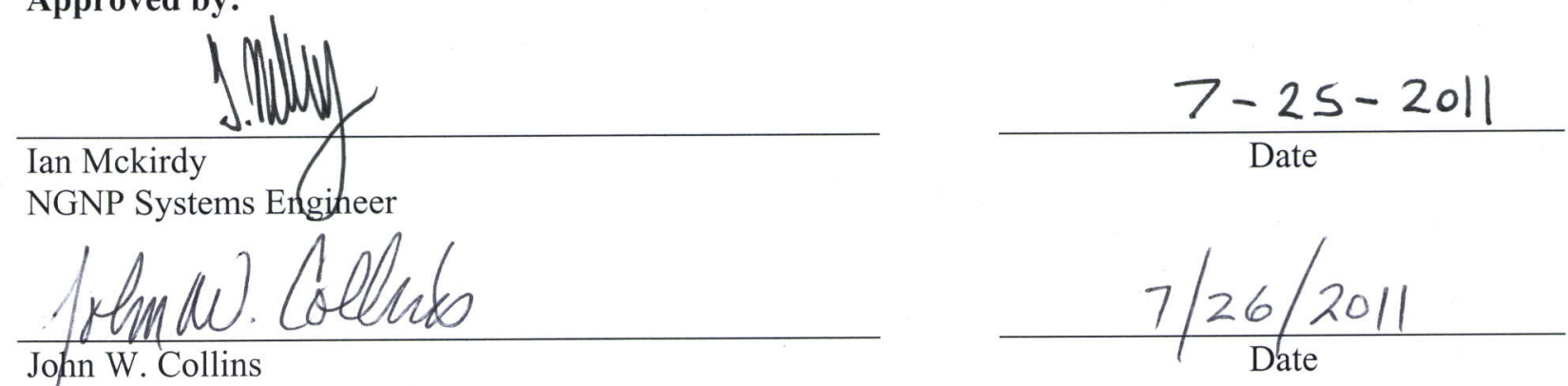

NGNP Lead Systems Engineer

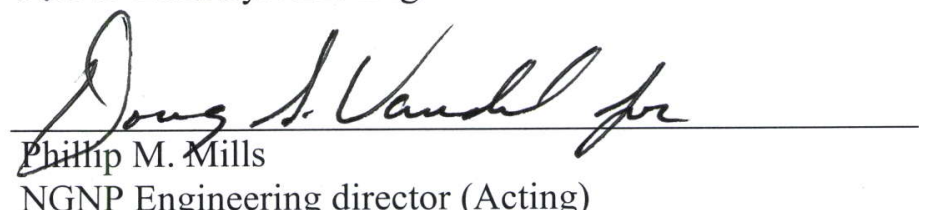

$$
\frac{7-25-2011}{\text { Date }}
$$

NGNP Engineering director (Acting) 
This page intentionally left blank. 


\section{EXECUTIVE SUMMARY}

The U.S. Department of Energy has selected the high temperature gas-cooled reactor design for the Next Generation Nuclear Plant (NGNP) Project. The NGNP will demonstrate the use of nuclear power to generate process heat for use in producing hydrogen, electricity, and other industrial applications. The reactor will be graphite moderated with helium as the primary coolant and may be either prismatic or pebble-bed (the final design features have not yet been determined).

Research and development (R\&D) are proceeding based on those plant systems known to mature the technology, codify the materials for specific applications, and demonstrate the component and system viability in NGNP relevant and integrated environments. Collectively, this R\&D serves to reduce project risks and enhance the probability of completing the NGNP project on budget and on schedule and receiving a Nuclear Regulatory Commission (NRC) license to operate the facility. As the project progresses toward final design and NRC approval to construct the plant, selected components that have not been used in a similar application and relevant environment, nor integrated with other components and systems, must be tested to demonstrate viability at reduced scales and simulations prior to full-scale operation.

This report and its R\&D Technology Development Roadmaps (TDRMs) present the path forward and its significance in assuring technical readiness to perform the desired function by choreographing the integration between design and $\mathrm{R} \& \mathrm{D}$ activities and proving selected design components in relevant applications.

The R\&D technical program plans discussed in this document identify the R\&D required for the firstof-a-kind (FOAK) NGNP and follow-on nth-of-a-kind (NOAK) reactors. The fundamental challenge for NGNP is to achieve a significant advancement in nuclear technology while setting the stage for an economically viable deployment of the new technology in the commercial sector.

This report documents the assessment of the status of the R\&D (current and planned) conducted at by the NGNP Project. The assessment:

- Establishes to what extent the R\&D technology development plans are meeting the Design Data Needs (DDNs)

- Identifies how the R\&D technology development plans are mitigating the risks and addressing the Phenomena Identification and Ranking Tables (PIRTs) associated with the NGNP risk register

- Relates the R\&D technology development plans to the actual technological development of the NGNP critical $^{\text {a }}$ structures, systems, and components

- Identifies the current Technology Readiness Levels (TRLs) of the NGNP R\&D activities and the necessary path forward to advance them

- Produces an executable R\&D strategy as depicted in the TDRMs.

The assessment is based on a number of sources: DDNs, risk and PIRT analyses, reactor vendor supplied TRL sheets, R\&D program schedules, and R\&D technology development plans.

Five main R\&D areas relate to NGNP technological development:

- Materials

- Fuels

a The use of the word 'critical' in this document implies being 'critical to the success of the NGNP project', not critical to or related to nuclear safety. 
- Graphite

- High Temperature Steam Electrolysis

- Methods.

Each program was examined using given data sources and the program leads were interviewed for their input via a series of meetings and discussions.

The assessment (1) identifies the critical systems being (and will be) technologically progressed by the R\&D technology development plans, (2) provides a brief overview of each system, (3) describes their main R\&D technology development test plans, (4) describes how DDNs are being met, (5) provides any additional technological development identified but that may not be currently in the program, (6) explains how risk and PIRTs are being mitigated, (7) and includes an R\&D TDRM for the system being progressed by the R\&D activities.

Where applicable, the systems have been split into FOAK and NOAK technology development to reflect the R\&D plans for components and or materials used by a particular system. The NGNP reactor components currently being advanced by the R\&D programs are reactor pressure vessel (RPV), intermediate heat exchanger (IHX), steam generator, fuel elements, high temperature steam electrolysis (HTSE) and graphite reactor core structures.

Not all NGNP critical systems are progressed technologically by the R\&D plans, some key examples would be the reactor cavity cooling system, reserve shutdown system, and the reactivity control system. Until the design of the NGNP has matured and is closer to being finalized, it is not possible to construct R\&D plans around these components. A recommendation is that, as the design matures, there should be further assessments of the critical systems that are not being progressed by the R\&D programs to establish if those systems could be furthered by R\&D activities to meet the NGNP goals.

\section{Observations}

The Materials program assumes that the FOAK RPV will be constructed using SA 508/533 steel. For the NOAK reactor module at higher reactor outlet temperatures, the program includes a strategy for the development of Grade 91 steel as a potential material candidate. The program does not consider the IHX to be included in the FOAK reactor module, but does address IHX development for the NOAK reactor module, with Alloy 617 addressed as the leading material candidate. The FOAK reactor module material candidate of concern for the steam generator is Alloy $800 \mathrm{H}$. On selection of a reactor design (and therefore potentially a specific reactor supplier), other candidate alloys such as Hastelloy X may be added to the Materials program for testing.

All of the fuel particles used in the Advanced Gas Reactor (AGR) program (apart from AGR-2) use UCO kernels. The fuel qualification program has shown very low particle failure with irradiation and heat-up testing with burnups, fluencies, and maximum temperatures.

Historical nuclear grades of graphite no longer exist so new grades must be fabricated, characterized, and irradiated to demonstrate acceptable properties for use as a core structure for the NGNP.

The highest-priority Method's activities for FY 2011 through 2013 will include conducting integral experiments in the High Temperature Test Facility and completing and operating the Natural Circulation Shutdown Test Facility.

At present, the single largest challenge for the High Temperature Steam Electrolysis program is defining the unacceptable level of performance degradation of the solid-oxide electrolysis cells. 


\section{Conclusions}

Conclusions from the Technology Readiness Assessment and the creation of TDRMs for the R\&D program development plans are as follows:

- The current technology development test plans for the NGNP R\&D programs apply to critical reactor components that require broad and fundamental R\&D. As the design matures further analysis is required to identify any additional components that may be on the critical path

- Until the NGNP reactor design is more mature and critical decision down-selects have been made, some key reactor components cannot be sufficiently advanced, resulting in increased risk being carried forward on the project, added costs for carrying multiple paths forward and possible delays to the schedule

- As the reactor outlet temperature increases to $850^{\circ} \mathrm{C}$ (and above), the number of reactor components required to be made from ceramic composites increases significantly. During a conduction cooldown scenario, the decay heat is too high for metallic materials, possibly requiring the replacement of reactor components. No INL ceramic composite R\&D program exists to advance the development, codification, and licensing of ceramic components.

- All of the INL NGNP R\&D technology programs are actively engaged in advancing the technology for the NGNP reactor components. Their focus is on ASME BPV codification, NRC licensing, satisfying DDNs, and addressing items of risk and PIRTs. ${ }^{b}$ There are no INL NGNP R\&D activities being pursued that are not in direct support of NGNP deployment.

b. Any omission or exceptions are identified in the main body of this document. 
This page intentionally left blank. 


\section{CONTENTS}

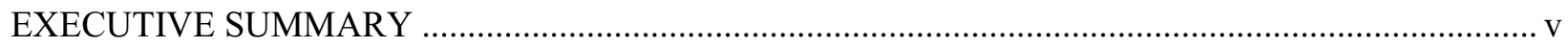

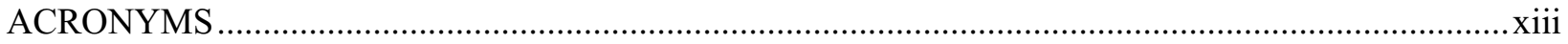

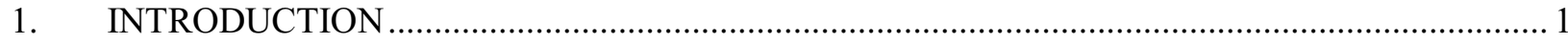

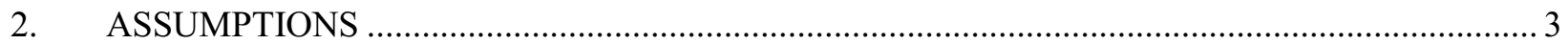

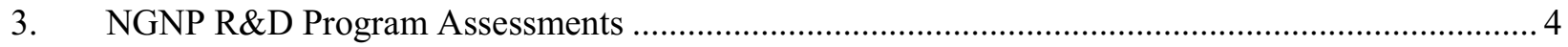

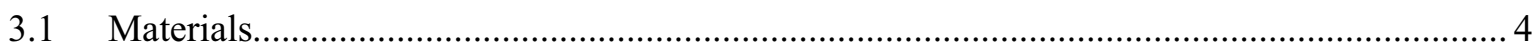

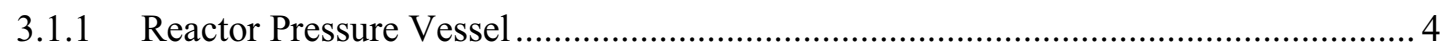

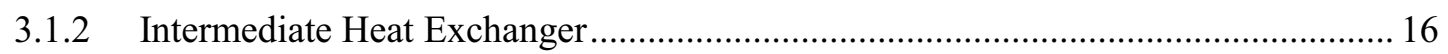

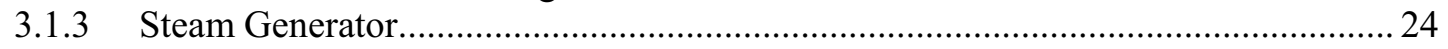

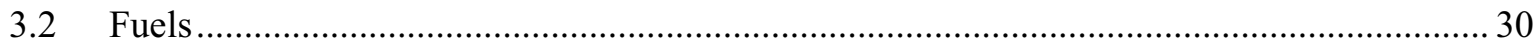

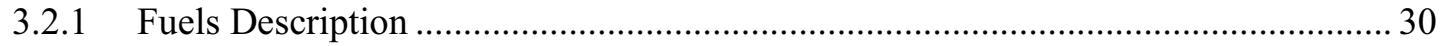

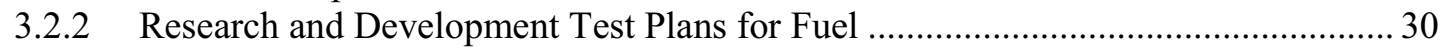

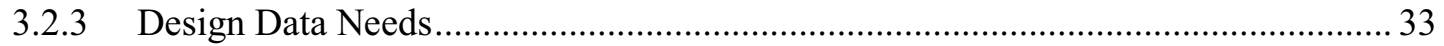

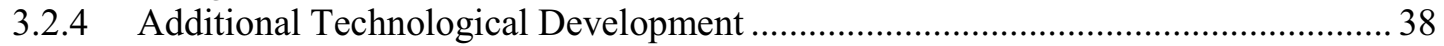

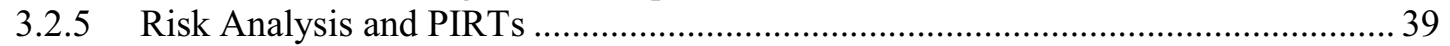

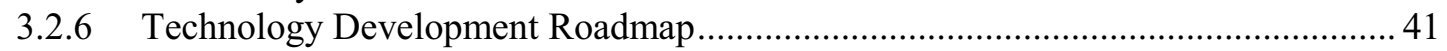

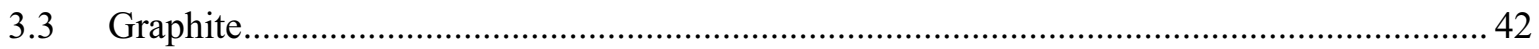

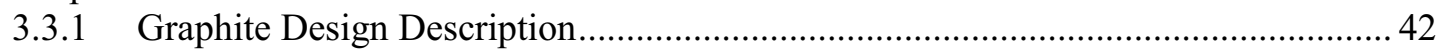

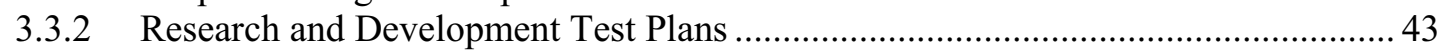

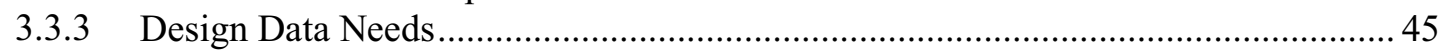

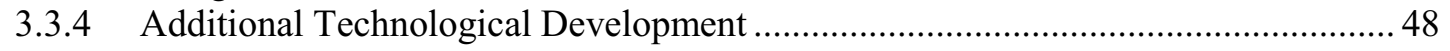

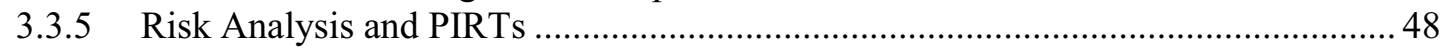

3.3.6 Nongraphite Core Structures (Ceramic Composites) ............................................. 50

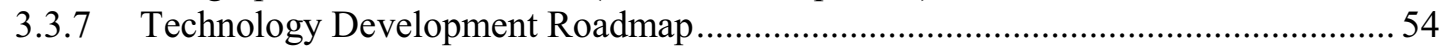

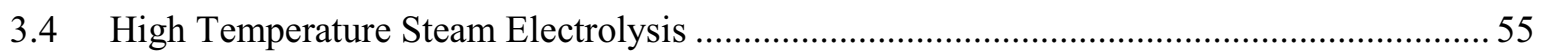

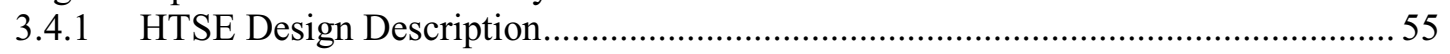

3.4.2 Research and Development Test Plans for HTSE.............................................. 55

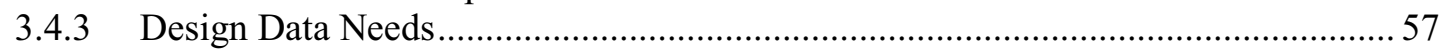

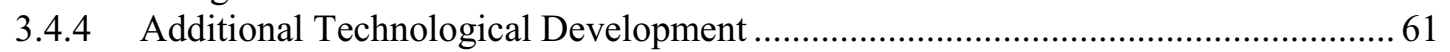

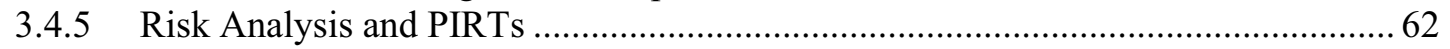

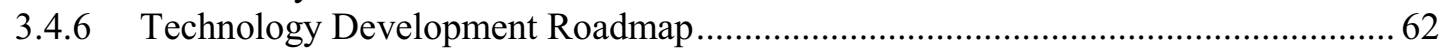

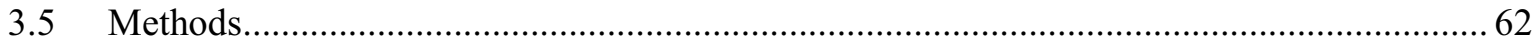

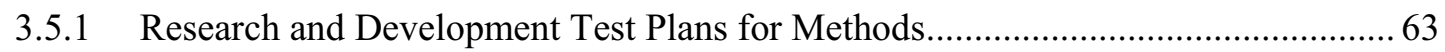

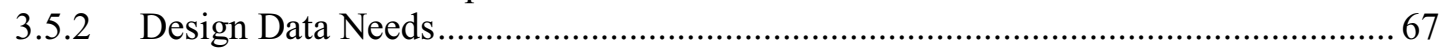

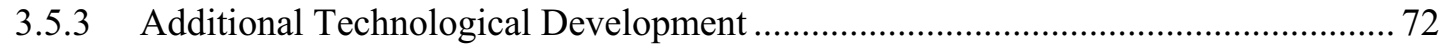

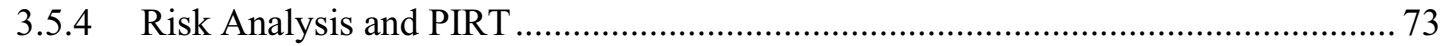

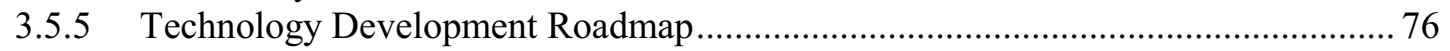

3.6 Nuclear Energy Research Initiative and Nuclear Energy University Program .................... 78

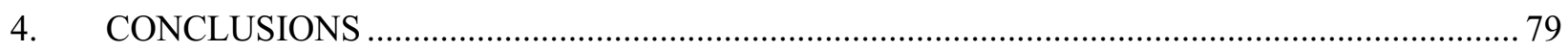

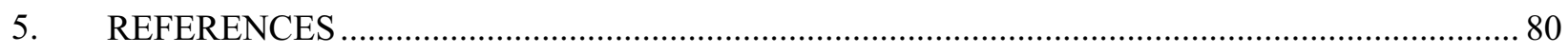




\section{FIGURES}

Figure 1. NGNP development process of R\&D TDRMs.................................................................. 2

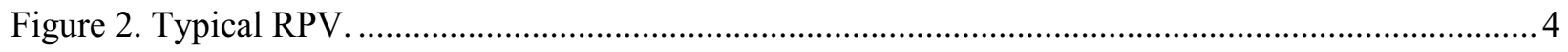

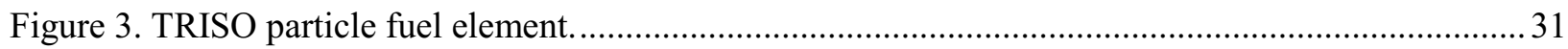

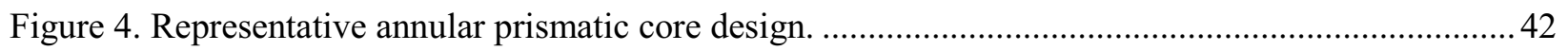

Figure 5. GA recommendations as reactor outlet temperatures increase for NGNP high

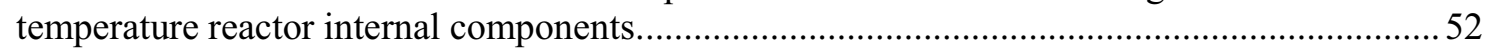

Figure 6. Overview of $15 \mathrm{~kW}$ INL Integrated Laboratory Scale (ILS) HTSE test facility....................... 55

Figure A-1. R\&D Materials Program reactor pressure vessel (FOAK)............................................... 83

Figure A-2. R\&D Materials Program reactor pressure vessel (NOAK) . ............................................... 84

Figure A-3. R\&D Materials Program intermediate heat exchanger (NOAK) . ........................................ 85

Figure A-4. R\&D Materials Program steam generator (FOAK) .......................................................... 86

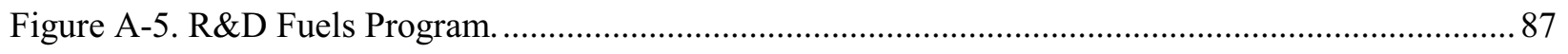

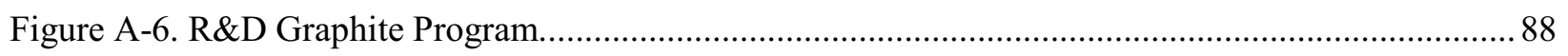

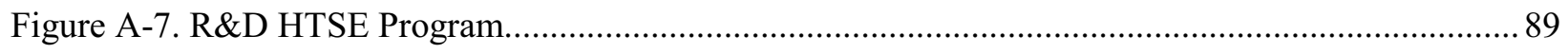

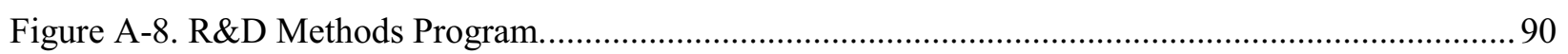

\section{TABLES}

Table 1. Summary of TRL level determined by reactor supplier and INL ............................................ 5

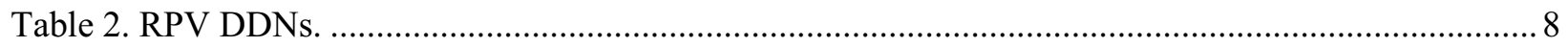

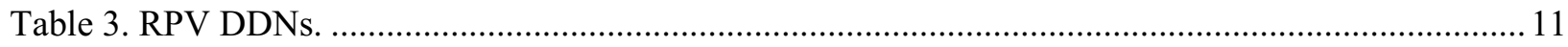

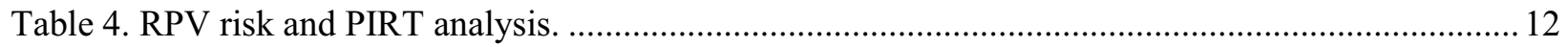

Table 5. IHX TRL determination by each reactor supplier and INL. .................................................... 16

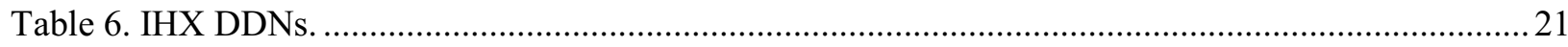

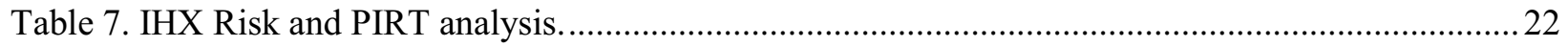

Table 8. Steam generator TRL determination by each reactor supplier and INL. ..................................25

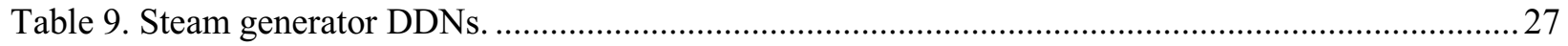

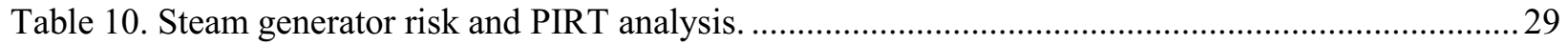

Table 11. Fuel TRL determination by each reactor supplier and INL..................................................31

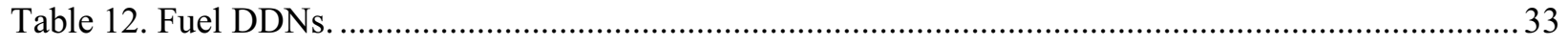

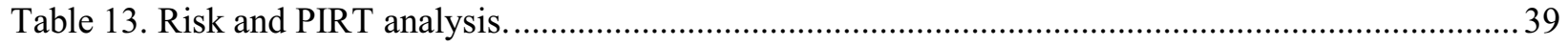

Table 14. TRL determination by each reactor supplier and INL. .......................................................... 43

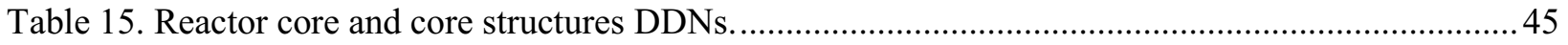




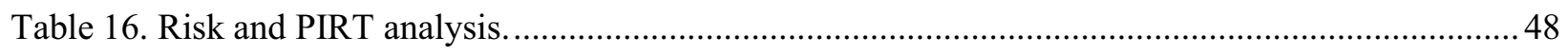

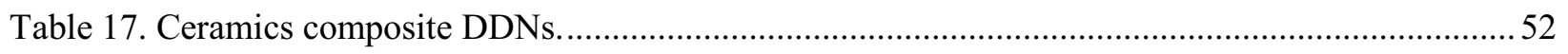

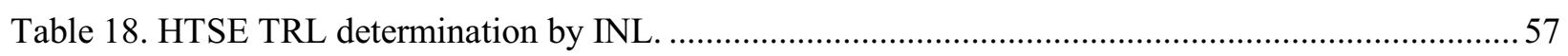

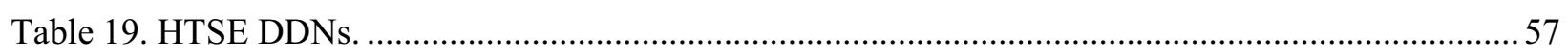

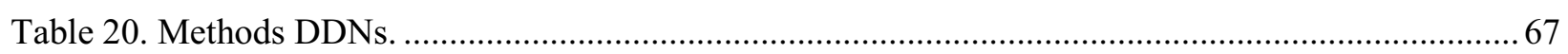

Table 21. PIRT for normal operation and conduction cooldown scenarios............................................. 74

Table 22. Areas being worked under NERI and NEUP.................................................................... 78 
This page intentionally left blank. 


\section{ACRONYMS}

ANL Argonne National Laboratory

AGC Advanced Graphite Creep

AGR Advanced Gas Reactor

ASME American Society of Mechanical Engineers

ASTM American Society for Testing and Materials

ATR Advanced Test Reactor

BOP balance-of-plant

BPV Boiler and Pressure Vessel (Code)

B\&W Babcock and Wilcox

CFD computational fluid dynamics

DCC depressurized conduction cooldown

DDN Design Data Need

DOE Department of Energy

DTF designed-to-fail

FOAK first-of-a-kind

GA General Atomics

GIF Generation IV Information Forum

GRS Gesellschaft für Anlagen und Reaktorsicherheit

GT-MHR Gas Turbine-Modular Helium Reactor

HTR-10 Chinese High Temperature Gas-Cooled Reactor

HTSE High Temperature Steam Electrolysis

HTTF High Temperature Test Facility

HTGR high temperature gas-cooled reactor

HTTR High Temperature Engineering Test Reactor (Japan)

HTV high temperature vessel

IHX intermediate heat exchanger

ILS integrated laboratory scale

INL Idaho National Laboratory

JAEA Japan Atomic Energy Agency

MHTGR Modular High Temperature Gas-cooled Reactor

NERI Nuclear Energy Research Initiative

NEUP Nuclear Energy University Program

NGFM Nodal Green's Function Method 


\begin{tabular}{|c|c|}
\hline NGNP & Next Generation Nuclear Plant \\
\hline NOAK & nth-of-a-Kind \\
\hline NRC & Nuclear Regulatory Commission \\
\hline NSTF & Natural Convection Shutdown Heat Removal Test Facility \\
\hline ORNL & Oak Ridge National Laboratory \\
\hline PBR & pebble bed reactor \\
\hline PCC & pressurized conduction cooldown \\
\hline PHTS & primary heat transport system \\
\hline PIE & post-irradiation examination \\
\hline PIRT & Phenomena Identification and Ranking Tables \\
\hline PyC & pyrolytic carbon \\
\hline QA & Quality Assurance \\
\hline QC & quality control \\
\hline $\mathrm{R} \& \mathrm{D}$ & research and development \\
\hline $\mathrm{RCCS}$ & reactor cavity cooling system \\
\hline RPV & reactor pressure vessel \\
\hline SAW & submerged arc weld \\
\hline SC-MHR & steam cycle modular helium reactor \\
\hline SG & steam generator \\
\hline SHTS & secondary heat transport system \\
\hline SMT & simplified model test \\
\hline SOEC & solid oxide electrolysis cell \\
\hline SRX & strength relaxation \\
\hline STAR & safety and tritium applied research \\
\hline TDRM & Technology Development Roadmap \\
\hline THAI & Thermal-hydraulics, Hydrogen, Aerosols, Iodine [Project] \\
\hline TRISO & tristructural isotropic (particles) \\
\hline TRL & Technology Readiness Level \\
\hline UCR & upper core restraint \\
\hline VHTR & very high temperature reactor \\
\hline VLPB & Vented Low-Pressure Building \\
\hline WSRF & weld strength rupture factor \\
\hline
\end{tabular}




\section{Research and Development Technology Development Roadmaps for the Next Generation Nuclear Plant Project}

\section{INTRODUCTION}

The Next Generation Nuclear Plant (NGNP) Project involves the deployment of a high temperature gas-cooled reactor (HTGR) that provides both electricity and process heat for industrial applications. The first, prototype HTGRs for the NGNP Project are expected to have a reactor outlet temperature between 750 and $850^{\circ} \mathrm{C}$, suitable for a large number of industrial applications. Other significant process heat applications, however, will likely require heat at much higher temperatures (on the order of $950^{\circ} \mathrm{C}$ ), and future HTGR plants will be expected to meet this demand. In order to achieve these temperatures, considerable technology development and test data are needed to advance plant design and licensing efforts.

This report assesses the status of both current and future NGNP research and development (R\&D) performed by the NGNP Project, which encompasses:

- Establishing to what extent the R\&D technology development plans are meeting the Design Data Needs (DDNs)

- Identifying how the R\&D plans are mitigating the risks and Phenomena Identification and Ranking Tables (PIRTs) associated with the NGNP risk register

- Relating the R\&D plans to the technological development of the NGNP critical structures, systems, and components

- Identifying the current Technology Readiness Levels (TRLs) of the NGNP R\&D activities

- Producing Technology Development Roadmaps (TDRMs) for the R\&D activities.

The assessment was conducted from a number of sources: DDNs, Risk and PIRT analysis, vendor supplied TRL sheets, R\&D program schedules and R\&D technology development plans.

There are five main areas of R\&D activity related to NGNP technological development:

- Materials

- Fuels

- Graphite

- High Temperature Steam Electrolysis

- Methods.

Each program was examined using given data sources and the program leads were interviewed for their input via a series of meetings and discussions.

The approach taken in compiling this assessment is identified pictorially in Figure 1. 
Inputs

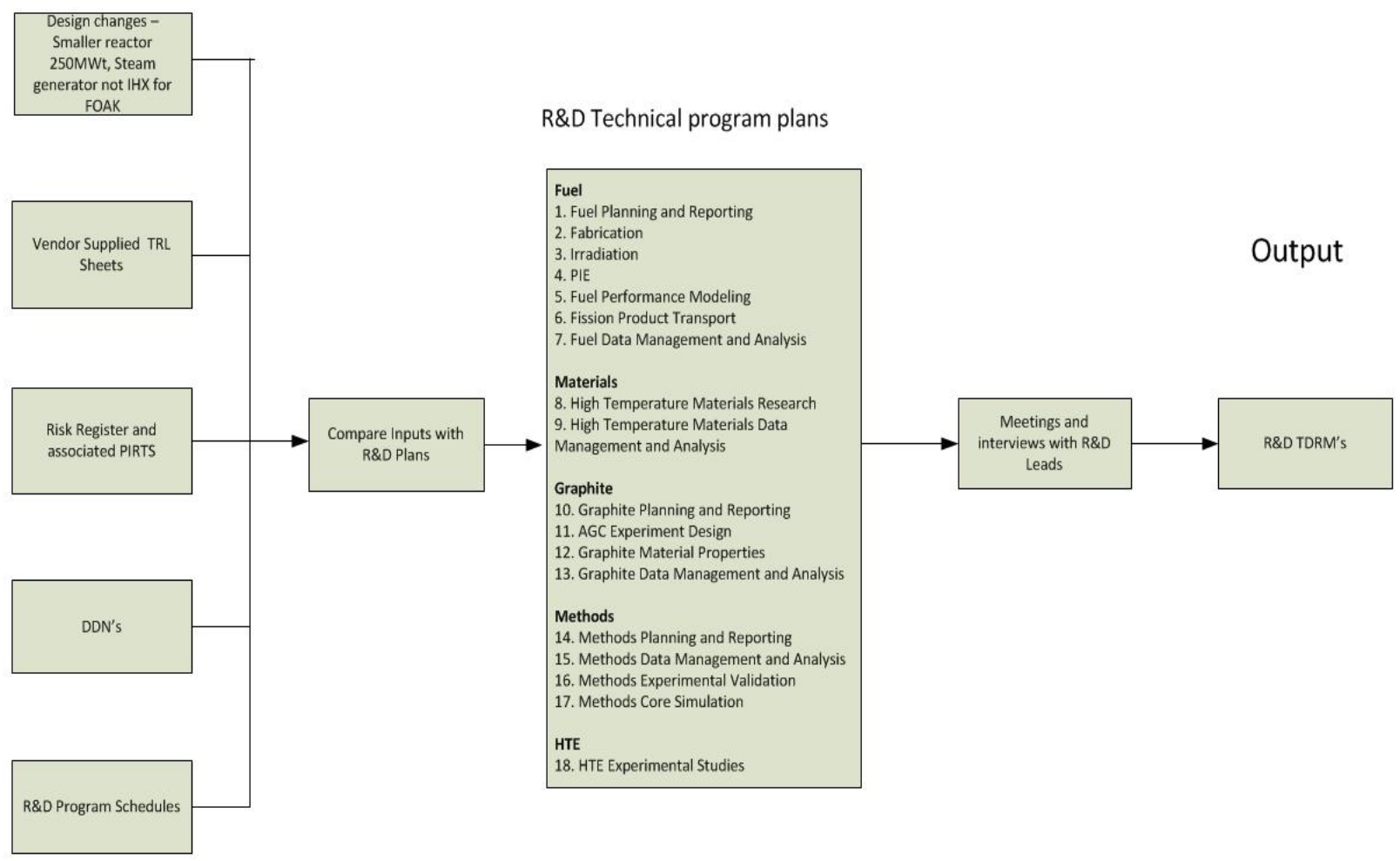

Figure 1. NGNP development process of R\&D TDRMs.

This assessment (1) identifies which critical systems are being (and will be) technologically progressed by the $R \& D$ plans (2) provides a brief overview each system, (3) describes the main $R \& D$ test plans, (4) explains how the DDNs are being met, (5) gives any additional technological development identified that may not currently be in the program, (6) explains how risk and PIRTs are being mitigated, (7) highlights gaps between identified development needs and current R\&D test plans (8) and includes an R\&D TDRM for the system being progressed by the R\&D activities.

Where applicable, the systems are split into first-of-a-kind (FOAK) and nth-of-a-kind (NOAK) technology development to reflect the R\&D plans for components and or materials used by a particular system. Not all NGNP critical systems are progressed technologically by R\&D plans, but those not progressed are still identified in this assessment. It is recommended that the critical systems not being progressed by the $R \& D$ programs be further assessed to establish if those systems require $R \& D$ to meet the NGNP goals. The output from the R\&D TDRMs will be integrated with the other deployment TDRMs. 


\section{ASSUMPTIONS}

The following assumptions were made in the development of the TDRMs for the NGNP R\&D program:

1. The NGNP reactor design will be down-selected in a timely manner such that duplicate and parallel R\&D efforts are not carried forward prohibitively into the preliminary design phase.

2. The reactor design is a helium-cooled, graphite-moderated core design fueled with tristructural isotropic (TRISO)-design fuel particles in carbon-based compacts or pebbles.

3. INL will continue to direct the NGNP Project based on the guidelines given in the Energy Policy Act of 2005.

4. The power level for the FOAK reactor configuration is $200-350 \mathrm{MW}(\mathrm{t})$ (megawatt thermal), the reactor outlet temperature is $750-850^{\circ} \mathrm{C}$, the primary coolant fluid is helium, and the primary pressure is 7-9 $\mathrm{MPa}$ (megapascal).

5. The power level for the NOAK reactor configuration is $200-600 \mathrm{MW}(\mathrm{t})$, the reactor outlet temperature is $750-950^{\circ} \mathrm{C}$, the primary coolant fluid is helium, and the primary pressure is 7-9 $\mathrm{MPa}$

6. The design, materials, and construction will need to meet appropriate Quality Assurance (QA) methods and criteria and other nationally recognized acceptance codes and standards. NGNP must demonstrate the capability to obtain a Nuclear Regulatory Commission (NRC) operating license.

7. The NGNP will be designed to operate for a nominal 60 years. 


\section{NGNP R\&D Program Assessments}

\subsection{Materials}

The R\&D Materials program is concerned with the technological development of materials for use in an HTGR. The three main components being progressed by the Materials program are the reactor pressure vessel (RPV), intermediate heat exchanger (IHX) and steam generator (SG). Each of these components is discussed in this section.

\subsubsection{Reactor Pressure Vessel}

The RPV houses the reactor, reactor internals, and core support structure.

\subsubsection{RPV Design Description}

The RPV consists of the containment and structure for the reactor core and control rods. The RPV is capable of withstanding the temperatures generated by the nuclear reaction. Figure 2 illustrates a typical RPV.

\section{Functions Performed}

The functions of the RPV System are to:

- House and support the components of the reactor core, reactor internals, and reactor support structure

- Maintain positioning relative to the control rods

- Contain the primary coolant inventory within a leak-tight pressure boundary

- Maintain the integrity of the coolant pressure boundary.

\subsubsection{Research and Development Test Plans}

INL PLN-2803, "Next Generation Nuclear Plant Reactor Pressure Vessel Materials Research and Development Plan" (Revision 1, July 14, 2010) identifies the tasks required to mature the RPV technology. Studies of potential steels for the RPV have focused on temperature limits and allowable stresses established by the American Society of Mechanical Engineers (ASME) Boiler and Pressure Vessel (BPV) Code. The leading NGNP RPV material contender is SA508 (forgings)/SA533 (plates) steel. The materials discussions for the RPV apply to all pressure vessels in

Figure 2. Typical RPV. the pressure vessel system (RPV, SG/IHX and cross-vessel).

\subsubsection{FOAK RPV}

NGNP Project R\&D plans have identified a development strategy based on the use of SA508/533 steel for the NGNP FOAK RPV with a $750-850^{\circ} \mathrm{C}$ outlet temperature and conventional steam cycle, which allows the use of light water reactor steels (SA508/533) for the RPV. The selection of this material greatly simplifies DDNs and RPV qualification because nuclear industry experience with this type of steel is extensive. 


\subsubsection{Reactor Pressure Vessel Status (FOAK)}

The RPV technology R\&D development plan details the additional R\&D needed to advance the NGNP RPV, assuming SA508/533 is the material of construction.

A detailed schedule provided by the INL R\&D materials program identifies the activities and durations that will mature the RPV technology from its current TRL-4 to a TRL-6 and beyond. This schedule was used in conjunction with the R\&D test plans to produce the TDRMs for the RPV.

The latest General Atomics (GA) Conceptual Design Report - Steam Cycle Modular Helium reactor (SC-MHR) Demonstration Plant (NGNP-R00016 Revision 0), identifies the TRL level needed for a FOAK RPV to be at TRL-6. This TRL reflects a significant improvement in the technology readiness of the SC-MHR concept relative to prior NGNP Project technology readiness assessments based on the Modular High-Temperature Gas-cooled Reactor (MHTGR) design.

INL has assigned TRL-4 to the FOAK RPV because there are still licensing and codification issues for SA508/533 steel related to long term creep behaviors to 500,000 hours service time and elevated temperatures.

Table 1. Summary of TRL level determined by reactor supplier and INL.

\begin{tabular}{|ccccc|}
\hline System & AREVA & GA & Westinghouse & INL \\
\hline RPV & 5 & 6 & None provided & 4 \\
\hline
\end{tabular}

\subsubsection{Research and Development Tasks}

This section discusses detailed plans to address code issues that support RPV development. The test references A1-A33 (given below) are taken from Table 11, "Summary of test plan for SA508/533 material - cold vessel," of PLN-2803. This section describes the main effects and properties of the materials to be tested, the purpose of the tests, the environmental conditions, and, where applicable, which code case they support. Further details on the conditions of the tests are presented in Table 11 of PLN-2803.

\section{Creep Effects on RPV Under Operating Conditions}

The Code Case $\mathrm{N}-499^{\mathrm{c}}$ database does not provide adequate creep rupture data to address the issue of whether creep effects for the RPV need to be considered under a normal operating temperature of $\sim 320^{\circ} \mathrm{C}$. Tests planned to support Conceptual Preliminary Design activities are:

\section{A1. Creep Rupture Tests Creep (Base metals)}

A2. Submerged Arc Weld (SAW) Cross-Weld Creep Rupture Tests (Weldments).

Environmental creep rupture tests planned to assess the potential impact of NGNP helium on the creep rupture strengths of SA508/533 steels and their weldments are:

A3. Creep Rupture Tests in NGNP Helium (He)

A4. SAW Creep Rupture Tests of Cross-Welds in NGNP He.

c. The latest version of Code Case N-499 has been fully incorporated into the new Section III, Division 5 of the ASME BPV Code. Division 5 provides construction rules for high temperature reactors, including HTGRs. Since Division 5 has not yet been published, this report will continue to refer to Code Case N-499. 
Tests planned for limited temperature excursions above the subsection NB cut-off temperature of $371{ }^{\circ} \mathrm{C}$ but within the time-and-temperature restrictions of Code Case N-499 are:

A5. Creep Rupture Tests on Fatigue-Strength Relaxation (SRX) Damaged Material

A6. SAW Creep Rupture Tests of Cross-Welds on Fatigue-SRX Damaged Material.

Longer term creep rupture tests planned in air for 5 year and 15 years are:

A7. Long-Term Qualifying Creep Rupture Tests

A8. SAW Long-Term Qualifying Creep Rupture Tests.

\section{Relaxation Strengths}

The relaxation strength is required to provide the limit to ensure that shakedown takes place so that ratcheting does not occur. Stress relaxation curves will be developed from the following tests:

- Tests covering the normal operating temperature and temperatures permitted in Code Case N-499 are:

A9. Relaxation Strength to Address Creep Effects

A10. SAW Relaxation Strength to Address Creep Effects.

- Testing conditions planned for determining the relaxation strengths for creep-fatigue damaged base metals and their associated weldments are:

A11. Relaxation Strength Tests of fatigue-SRX Damaged SA508/533

A12. Relaxation Strength Tests of Fatigue-SRX Damaged SAW Cross-Welds.

\section{Creep-Fatigue Tests}

The following creep-fatigue tests will measure fatigue-stress relaxation behavior for SA508/533 steels and their associated weldments to assist the assessment of whether creep needs to be considered for the RPV under normal operating temperature:

- A13. Fatigue-SRX Tests

- A14. SAW Fatigue-SRX Tests.

\section{Effects on Tensile Properties}

Thermal aging and creep-fatigue damage accumulated during short-term high-temperature excursions would potentially degrade tensile properties and thus impact the ratcheting resistance. The following tensile tests are proposed to determine the baseline tensile properties in the simulated stress relief condition:

- Baseline tensile properties tests:

A15. Baseline Tensile Tests

A16. Baseline Tensile Tests of SAW Cross-Welds.

- Creep-fatigue damaged condition:

A17. Tensile Tests of Fatigue-SRX Damaged SA508/533

A18. Tensile Tests of Fatigue-SRX Damaged Cross-Welds.

- Thermally aged condition:

A19. Tensile Tests of Thermally Aged SA508/533 
A20. Tensile Tests of Thermally Aged Cross-Welds

A21. Tensile Tests of Long-Term Thermally Aged SA508/533

A22. Tensile Tests of Long-Term Thermally Aged SAW Cross-Welds.

\section{Fracture Toughness}

There are two fracture issues of concern for the NGNP RPV in the low temperature, brittle regime. First, very long-term thermal aging accumulated during the normal operations at $350^{\circ} \mathrm{C}$ for the $\sim 60$ year service life may cause embrittlement resulting in potential negative impact on the fracture toughness. Second, creep-fatigue damage accumulated during the short-term high-temperature excursions that are permitted by Code Case N-499.

- Data required to address the leak-before-break issue on the NRC concerns:

A23. Baseline Toughness Measurements (Master Curve To and J-R Curve) Base Metals

A24. Toughness Measurement (Master Curve To and J-R Curve) for Fatigue-SRX Damaged Material

A25. Toughness Measurement (Master Curve To and J-R Curve) for Thermally Aged Material (Aged at $450^{\circ} \mathrm{C}$ for $20,00 \mathrm{~h}$ )

A26. Toughness Measurement (Master Curve To and J-R Curve) for Thermally Aged Material (Aged at $450^{\circ} \mathrm{C}$ for $70,00 \mathrm{~h}$ )

- Testing of weldments where the crack is aligned within the weldment include:

A27. SAW Baseline Toughness Measurements (Master Curve To and J-R Curve) Weldment

A28. SAW Baseline Toughness Measurements (Master Curve To and J-R Curve) Weldment Heat Affected Zone.

\section{Cyclic Stress-Strain Curve}

Cyclic stress-strain curves are required to determine the cyclic response. Cyclic hardening, cyclic softening, or cyclic neutral material behavior is important in establishing the negligible creep criterion to support the Code Case N-499 effort. Testing to develop cyclic stress-strain curves at 20, 350, 371, 427, and $538^{\circ} \mathrm{C}$ consist of:

A29. Cyclic Stress-Strain Curves for A 508.

\section{Testing to Support Reevaluation of Code Case N-499}

Data that supported this code case were from SA533B (rolled) steel, creep-fatigue damage data for SA508/533 is not available. The following tests are proposed to address these database issues:

- Short-term creep rupture tests that cover the applicable durations of the code case for base metal and weldments:

A30. Creep Rupture Tests in Air

A31. SAW Cross-Weld Creep Rupture Tests.

- Code Case N-499 database Creep-fatigue tests for base metals and weldments:

A32. Fatigue-SRX Tests

A33. SAW Cross-Weld Fatigue-SRX Tests. 


\subsubsection{Design Data Needs}

Several DDNs are associated with the technological development of the NGNP RPV. The test references in the 'Status' column given below for A1-A33 are taken from Table A-1 in Appendix A of PLN-2803. The first three column references are from DDN documents (see 'References' section, numbers 15,16 and 17).

Table 2. RPV DDNs.

\begin{tabular}{|c|c|c|c|}
\hline Number & Vendor & Description & Status (covered by tests) \\
\hline 2.2 .1 .1 & AREVA & $\begin{array}{l}\text { RPV High Temperature Material. } \\
\text { Mechanical properties on heavy section } \\
\text { products (base and weld metal). } \\
\text { - Effect of aging. }\end{array}$ & $\begin{array}{l}\text { The data need is covered by Tests A5, } \\
\text { A6, and A7. }\end{array}$ \\
\hline 2.2.4.1 & AREVA & $\begin{array}{l}\text { RPV Low Temperature Material: } \\
\text { - } \quad \text { Effect of irradiation } \\
\text { - } \text { Creep during high temperature, } \\
\text { short duration (100h) excursions } \\
\text { - } \quad \text { Corrosion in helium environment } \\
\text { - Emissivity (in air and helium, and } \\
\text { considering emissivity degradation). }\end{array}$ & $\begin{array}{l}\text { The data need is covered by tests A3 } \\
\text { and A4. }\end{array}$ \\
\hline $2.2 .4 .1 \mathrm{~b}$ & AREVA & $\begin{array}{l}\text { Time Dependent Material Properties of } \\
\text { SA508/533 in an HTGR Environment. }\end{array}$ & $\begin{array}{l}\text { The data need is covered by tests A5 } \\
\text { and A7. }\end{array}$ \\
\hline $2.2 .4 .1 \mathrm{c}$ & AREVA & $\begin{array}{l}\text { Corrosion Effects on SA508/533 in a } \\
\text { HTGR Environment. }\end{array}$ & $\begin{array}{l}\text { The data need is covered by tests A3, } \\
\text { A4, and Nuclear Energy University } \\
\text { Program (NEUP). }\end{array}$ \\
\hline M.11.06.02 & GA & $\begin{array}{l}\text { Determine Properties of SA533B (Mn- } \\
1 / 2 \mathrm{Mo}-1 / 2 \mathrm{Ni}) \text { Base Metal and } \\
\text { Weldment at Elevated Temperatures. }\end{array}$ & $\begin{array}{l}\text { The data need is covered by tests } \\
\text { A22, A27. }\end{array}$ \\
\hline $2.2 .4 .1 \mathrm{a}$ & AREVA & $\begin{array}{l}\text { Irradiation Effects on SA508/533 in a } \\
\text { HTGR Environment. }\end{array}$ & $\begin{array}{l}\text { Not addressed. The INL Materials } \\
\text { program stance is that the irradiation } \\
\text { effects are well known in the } \\
\text { temperature range of light water } \\
\text { reactor vessels. Although NGNP } \\
\text { temperatures are expected to differ } \\
\text { from light water reactor temperatures, } \\
\text { the fluence is estimated to be roughly } \\
\text { an order of magnitude less for the } \\
\text { NGNP RPV. Therefore studies of } \\
\text { irradiation effects on long-term creep } \\
\text { and creep-fatigue are not planned at } \\
\text { this time. }\end{array}$ \\
\hline $2.2 .21 \mathrm{~d}$ & AREVA & $\begin{array}{l}\text { Emissivity of SA } 508 / 533 \text {. Emissivity } \\
\text { data has not yet been found to exist. } \\
\text { Any data obtained must meet the QA } \\
\text { requirements of } 10 \text { CFR } 50 \text {, Appendix } \\
\text { B. }\end{array}$ & $\begin{array}{l}\text { There are no R\&D test plan activities } \\
\text { related to the emissivity of } \\
\text { SA508/533 RPV steel internal to the } \\
\text { INL NGNP R\&D project. There is } \\
\text { however testing of emissivity of the } \\
\text { candidate materials currently ongoing } \\
\text { at University of Wisconsin under a } \\
\text { Nuclear Energy Research Initiative } \\
\text { (NERI) program. }\end{array}$ \\
\hline
\end{tabular}




\subsubsection{Additional Technological Development}

There are no additional technological development items identified in the Material's test plan to further NGNP technological development.

\subsubsection{Technology Development Roadmap (FOAK)}

Appendix A contains the TDRM for NGNP R\&D FOAK RPV.

\subsubsection{NOAK RPV}

NGNP R\&D plans identify a development strategy for a NOAK NGNP based on the use of Grade 91 steel. This option is known as the hot vessel option, which could require the use of higher temperature alloys. This design minimizes active cooling of the vessel and allows the RPV to operate at a higher temperature. For Grade 91 the design temperatures may be $>371{ }^{\circ} \mathrm{C}$ but less than the maximum allowable temperature specified in Section III, Subsection NH, for the RPV steel.

Grade 91 steel is approved in Section III of the ASME BPV Code, Division 1, Subsection NH. It is codified for a service life up to 300,000 hours. The current design concept of 60 years would require a service life up to 500,000 hours. Considerably more development is required for this steel compared to SA508/533, including additional irradiation testing for expected NGNP operating temperatures, hightemperature mechanical properties, and extensive studies of long-term microstructural stability.

There is an alternative RPV design that has a modified coolant flow through the RPV, such that it would keep the internal reactor temperature down to a point where Grade 91 steel would not be required for an elevated outlet temperature required for a NOAK HTGR. This option is known as the 'Cooled Vessel' option.

\subsubsection{Reactor Pressure Vessel Status (NOAK)}

The RPV technology R\&D development plan details the additional R\&D required to design and license the NGNP RPV hot vessel option, with the assumption that Grade 91 steel is the material of construction.

There is currently no schedule for implementing the R\&D test plans to mature the RPV technology for Grade 91 steel from the current TRL-4 to a TRL-6 and beyond.

\subsubsection{Research and Development Tasks}

This section discusses the detailed plans to address the code and licensing issues highlighted for the hot vessel options for Grade 91 steel. Table 2 in Appendix A of PLN-2803 details the planned R\&D tests to further the RPV technology development for Grade 91 steel.

The major concern with Grade 91 steel for NGNP RPV application is the adequacy of thick section properties of the base metal (as-received and post-weld heat treated), and weldments.

The following information gives the main effects and properties of the tests and environmental conditions. Table 2 in Appendix A of PLN-2803 gives further details about the testing conditions of the tests. 


\section{Negligible Creep Temperature for Grade 91 Steel}

The following tests address creep, creep rupture, and creep-fatigue tests to support the assessment of negligible creep conditions, expand the Grade 91 creep database, and provide creep-fatigue data to validate the negligible creep temperature recommended by the Department of Energy (DOE)/ASME Standards Technology, LLC /DOE:

- Creep rupture tests for test temperatures of 425,450 , and $475^{\circ} \mathrm{C}$ :

$\mathrm{C} 1 \mathrm{Creep}$ Tests at $425^{\circ} \mathrm{C}$ to Support Determination of Negligible Creep Temperature for Grade 91 Steel

C2 Creep Tests at $450^{\circ} \mathrm{C}$ to Support Determination of Negligible Creep Temperature for Grade 91 Steel

C3 Creep Tests at $475^{\circ} \mathrm{C}$ to Support Determination of Negligible Creep Temperature for Grade 91 Steel.

- Expand the creep database

C4 Creep to Extend Grade 91 Steel Database.

\section{Creep-Fatigue Testing}

There are two creep-fatigue protocols for the improvement of ASME BPV Code, Section III, Division1, Subsection NH Rules. One is a fatigue-relaxation test and the other a creep-fatigue test:

- Test matrices for the fatigue-relaxation and creep-fatigue tests:

C6. Fatigue-Relaxation Tests at $500^{\circ} \mathrm{C}$

C7 Creep-Fatigue Tests at $500^{\circ} \mathrm{C}$ (stress control)

C8. Fatigue-Relaxation Tests for Grade 91 Steel at $550^{\circ} \mathrm{C}$

C9. Creep-Fatigue Tests for Grade 91 Steel at $550^{\circ} \mathrm{C}$

- Fatigue-relaxation and creep-fatigue test matrices at $500^{\circ} \mathrm{C}$ for aged material where the aging protocol is 20,000 hours:

C10. Fatigue-Relaxation Tests at $500^{\circ} \mathrm{C}$ for Aged Grade 91 Steel

C11. Creep-Fatigue Tests at $500^{\circ} \mathrm{C}$ for Aged Grade 91 Steel

- Creep rupture tests of thick section welds:

C13. Weld Stress Rupture Factor for SAW, gas tungsten arc welding, and Shielded Metal Arc Welding Cross-Welds

- Creep rupture tests on Grade 91 specimens that have been softened by creep-fatigue pre-conditioning:

C14. Short \& Medium Term Creep Tests on Creep Fatigue Softened Samples

- Tensile tests on creep-fatigue softened Grade 91 specimens:

C15. Tensile Tests for Creep Fatigue Softened Samples at $550^{\circ} \mathrm{C}$

- Testing to support the development of a design continuous cycling fatigue curve at $650^{\circ} \mathrm{C}$ for use in Subsection NH:

C16. Test Matrix for Grade 91 Steel Fatigue Design Curve at $650^{\circ} \mathrm{C}$. 


\subsubsection{Design Data Needs}

DDNs associated with the technological development of the NGNP RPV are listed in Table 3 . The first three column references are from DDN documents (see 'References' section, numbers 15, 16 and 17).

Table 3. RPV DDNs.

\begin{tabular}{|c|c|c|c|}
\hline Number & Vendor & Description & Status (covered by tests) \\
\hline 2.2.3.1h & AREVA & $\begin{array}{l}\text { Material Properties of Grade } 91 \\
\text { in a HTGR Environment up to } \\
650^{\circ} \mathrm{C} \text {. }\end{array}$ & $\begin{array}{l}\text { This data need is covered by tests C13. There } \\
\text { is currently no schedule for these tests in the } \\
\text { RPV test plan. }\end{array}$ \\
\hline $2 \cdot 2.3 .1 \mathrm{~d}$ & AREVA & $\begin{array}{l}\text { Corrosion Effects on Grade } 91 \\
\text { in a HTGR Environment. }\end{array}$ & $\begin{array}{l}\text { The data need is covered by tests } \mathrm{C} 6 \text { and } \mathrm{C} 7 . \\
\text { There is currently no schedule for these tests } \\
\text { in the RPV test plan. }\end{array}$ \\
\hline 2.2.3.1f & AREVA & $\begin{array}{l}\text { Irradiation Effects on Grade } 91 \\
\text { in a HTGR Environment. }\end{array}$ & Not addressed \\
\hline N.12.01.03 & GA & $\begin{array}{l}\text { Reactor Vessel Emissivity - } \\
\text { Reactor Vessel Emissivity } \\
\text { Grade } 91 \text { Forging. }\end{array}$ & $\begin{array}{l}\text { There are no test plan activities related to the } \\
\text { emissivity of Grade } 91 \text { steel internal to the } \\
\text { INL NGNP R\&D project; there is however } \\
\text { testing of emissivity of the candidate } \\
\text { materials currently ongoing at University of } \\
\text { Wisconsin under a NERI project. }\end{array}$ \\
\hline
\end{tabular}

\subsubsection{Additional Technological Development}

A number of tasks or programs have been identified that need to be performed to advance the technology development of the hot vessel option RPV Grade 91 steel. This section identifies some programs that are being proposed to be performed but there is no specific test plan identified for this work. There is also no schedule identified for these activities. These are effectively follow-on activities to be performed at a later date.

\section{Irradiation Effects}

Longer term ( $\sim$ two years) and low flux irradiation data are needed to address the concern of the synergistic effect of irradiation enhanced segregation of embrittling impurities on grain boundaries. A proposed program would include irradiation of tensile specimens, compact tension specimens for fracture toughness evaluation. There are probably only three reactors left in North America and two reactors in Europe that are capable of performing such irradiation experiments.

\section{Define Adequate Weldments}

Grade 91 steel requires post-weld quench and temper heat treatment to achieve maximum high temperature properties. In addition to standard specifications for post-weld examination (e.g., inspection for lack of fusion), the microstructure must be characterized. The current ASME BPV Code rules specify a maximum hardness in order to ensure that proper tempering treatment has been carried out. An additional specification will be required for minimum hardness to ensure that the quench from the austenitizing temperature was sufficient to avoid formation of ferrite and coarse carbides. 


\section{Define Testing Schemes for Prototypical Weldments}

Testing schemes that need to be developed for prototypical Grade 91 weldments include:

1. Characterize the microstructure of the welds to determine whether the desired microstructures are achieved, and delta ferrite is limited within the allowable standards stipulated by ASME BPV Code, Section III, Division 1, Subsection NH.

2. Evaluate the integrity of the fabricated weldment in optimizing the filler metals and processing parameters.

3. Generate some verification data for the weld strength factor, such as the stress-rupture factor for welds needed for Tables I-14.10 of Mandatory Appendix I of ASME BPV Code, Section III, Division 1, Subsection NH.

\section{Post-Weld Heat Treatment}

Customized post-weld heat treatment procedures must be developed for Grade 91. Post-weld heat treatment must be adjusted, depending on the filler metal employed, to achieve the desired microstructure and mechanical properties.

\subsubsection{Risk Analysis and PIRTs}

The NGNP risks database (NGNP_RMS_V2_D_15SEP2010.mdb) identifies a number of risks and PIRTs associated with the RPV. Table $\overline{4}$ identifies how those risks are mitigated by the RPV R\&D test plans. The test references given below for A1-A33 and $\mathrm{C} 1-\mathrm{C} 16$ are taken from Table 11 and Table B-6 in PLN-2803.

Table 4. RPV risk and PIRT analysis.

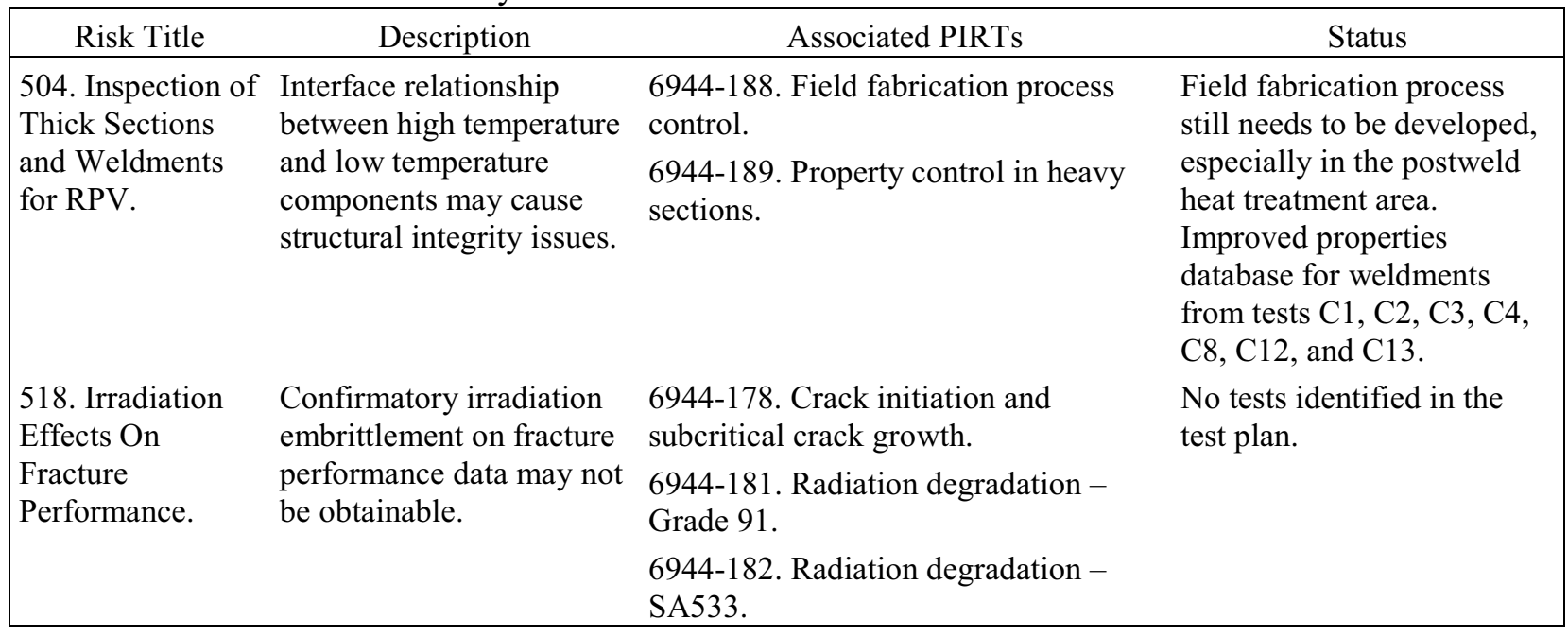


Table 4. (continued).

\begin{tabular}{|c|c|c|c|}
\hline Risk Title & Description & Associated PIRTs & Status \\
\hline $\begin{array}{l}541 . \text { NRC Issues } \\
\text { Identified In } \\
\text { PIRT and Not } \\
\text { Addressed by } \\
\text { Vendors for the } \\
\text { RPV. }\end{array}$ & $\begin{array}{l}\text { NRC Issues Identified In } \\
\text { PIRT and Not Addressed } \\
\text { by Vendors. }\end{array}$ & $\begin{array}{l}\text { 6944-60. Cavity overpressurization. } \\
\text { 6944-77. Chimney effects. } \\
\text { 6944-157. Corrosion products. } \\
\text { 6944-191. Crack initiation and } \\
\text { subcritical crack growth in power } \\
\text { conversion vessel. } \\
\text { 6944-79. Environment-to-confinement } \\
\text { air leakage. } \\
\text { 6944-158. Erosion products, } \\
\text { noncarbon. } \\
\text { 6944-192. High cycle fatigue in power } \\
\text { conversion vessel. } \\
\text { 6944-61. Pressure pulse in } \\
\text { confinement. } \\
\text { 6944-161. Radiolysis effects in } \\
\text { confinement. }\end{array}$ & $\begin{array}{l}\text { General material fatigue, } \\
\text { creep and corrosion test are } \\
\text { identified in the test plan } \\
\mathrm{C} 1-\mathrm{C} 16 \text {. }\end{array}$ \\
\hline $\begin{array}{l}\text { 506. RPV } \\
\text { Emissivity vs. } \\
\text { Power Level. }\end{array}$ & $\begin{array}{l}\text { RPV emissivity may be } \\
\text { less than } 1 .\end{array}$ & $\begin{array}{l}\text { 6944-183. Compromise of emissivity } \\
\text { due to loss of desired surface layer } \\
\text { properties. } \\
\text { 6944-35. Core barrel emissivity. } \\
\text { 6944-156. Dust deposition on vessel } \\
\text { and Reactor Cavity Cooling System } \\
\text { (RCCS) hardware. } \\
\text { 6944-19. RCCS heat removal. } \\
\text { 6944-106. RCCS performance with } \\
\text { "gray gas" in cavity. } \\
\text { 6944-33. Reactor vessel cavity "gray } \\
\text { gas" (participating media). } \\
\text { 6944-32. Reactor vessel cavity air } \\
\text { circulation and heat transfer. } \\
6944-18 . \text { Side reflector-core barrel- } \\
\text { vessel heat transfer. } \\
\text { 6944-29. Vessel emissivity. } \\
6944-31 . \text { Vessel to RCCS effective } \\
\text { view factors. }\end{array}$ & $\begin{array}{l}\text { No emissivity tests } \\
\text { identified in test plan. } \\
\text { Testing of emissivity of the } \\
\text { candidate materials } \\
\text { currently ongoing at } \\
\text { University of Wisconsin } \\
\text { under a NERI project. }\end{array}$ \\
\hline
\end{tabular}


Table 4. (continued).

\begin{tabular}{|c|c|c|c|}
\hline Risk Title & Description & Associated PIRTs & Status \\
\hline $\begin{array}{l}\text { 507. RPV Loss- } \\
\text { of-Coolant } \\
\text { Strength and } \\
\text { Creep Resistance. }\end{array}$ & $\begin{array}{l}\text { The effects of loss of } \\
\text { coolant and creep } \\
\text { resistance may be } \\
\text { unknown at design } \\
\text { temperatures and } \\
\text { durations during optimal } \\
\text { conditions. }\end{array}$ & $\begin{array}{l}\text { 6944-177. Crack initiation and } \\
\text { subcritical crack growth. } \\
\text { 6944-178. Crack initiation and } \\
\text { subcritical crack growth. } \\
\text { 6944-184. Creep (transient). } \\
\text { 6944-185. Creep (transient). } \\
\text { 6944-179. High Cycle Fatigue. } \\
\text { 6944-180. High Cycle Fatigue. } \\
\text { 6944-175. Thermal aging (short term, } \\
\text { high temperature). } \\
\text { 6944-176. Thermal aging (short term, } \\
\text { high temperature). } \\
\text { 6944-29. Vessel emissivity. }\end{array}$ & $\begin{array}{l}\text { Creep resistance, fatigue } \\
\text { and thermal aging covered } \\
\text { by tests } \mathrm{C} 1-\mathrm{C} 16 .\end{array}$ \\
\hline $\begin{array}{l}\text { 515. RPV: Vessel } \\
\text { Size/Fabrication. }\end{array}$ & $\begin{array}{l}\text { Fabrication techniques for } \\
\text { forging large RPV } \\
\text { associated with very high } \\
\text { temperature reactors } \\
\text { (VHTRs) have not been } \\
\text { developed. }\end{array}$ & $\begin{array}{l}\text { 6944-188. Field fabrication process } \\
\text { control. } \\
6944-189 . \text { Property control in heavy } \\
\text { sections. }\end{array}$ & $\begin{array}{l}\text { Field fabrication process } \\
\text { still needs to be developed } \\
\text { especially in the post weld } \\
\text { heat treatment area. } \\
\text { Improved properties } \\
\text { database for weldments } \\
\text { from tests } \mathrm{C} 1, \mathrm{C} 2, \mathrm{C} 3, \mathrm{C} 4 \text {, } \\
\mathrm{C} 8, \mathrm{C} 12 \text { and } \mathrm{C} 13 \text {. }\end{array}$ \\
\hline $\begin{array}{l}\text { 519. Temperature } \\
\text { Effects On } \\
\text { Mechanical } \\
\text { Properties of } \\
\text { Grade } 91 .\end{array}$ & $\begin{array}{l}\text { Grade } 91 \text { thick section } \\
\text { forging, elevation } \\
\text { temperatures for its welds, } \\
\text { and its mechanical } \\
\text { property database may } \\
\text { need to be obtained. }\end{array}$ & $\begin{array}{l}\text { 6944-186. Creep (normal operations). } \\
\text { 6944-187. Creep (normal operations). } \\
\text { 6944-173. Thermal aging (long term). } \\
\text { 6944-174. Thermal aging (long term). } \\
\text { 6944-175. Thermal aging (short term, } \\
\text { high temperature). } \\
\text { 6944-176. Thermal aging (short term, } \\
\text { high temperature). }\end{array}$ & $\begin{array}{l}\text { Creep and thermal aging for } \\
\text { thick forgings are covered } \\
\text { by tests C1-C16. }\end{array}$ \\
\hline $\begin{array}{l}\text { 540. Temperature } \\
\text { of Pressure } \\
\text { Boundary for } \\
\text { RPV. }\end{array}$ & $\begin{array}{l}\text { Temperature of Pressure } \\
\text { Boundary. }\end{array}$ & $\begin{array}{l}\text { 6944-186. Creep (normal operations). } \\
\text { 6944-184. Creep (transient). } \\
\text { 6944-185. Creep (transient). }\end{array}$ & $\begin{array}{l}\text { Creep resistance, fatigue } \\
\text { and thermal aging covered } \\
\text { by tests } \mathrm{C} 1-\mathrm{C} 16 .\end{array}$ \\
\hline $\begin{array}{l}\text { 508. Unavailable } \\
\text { Data for Long- } \\
\text { term Thermal } \\
\text { Aging Effects of } \\
\text { SA508. }\end{array}$ & $\begin{array}{l}\text { Thermal aging effects of } \\
\text { SA508 are promising but } \\
\text { additional information is } \\
\text { needed on the long-term } \\
\text { aging effects. }\end{array}$ & $\begin{array}{l}\text { 6944-190. Thermal aging. } \\
\text { 6944-173. Thermal aging (long term). } \\
\text { 6944-174. Thermal aging (long term). } \\
\text { 6944-175. Thermal aging (short term, } \\
\text { high temperature). } \\
\text { 6944-176. Thermal aging (short term, } \\
\text { high temperature). }\end{array}$ & $\begin{array}{l}\text { Thermal aging of SA } 508 \\
\text { steel addressed by tests } \\
\text { A19, A20, A21, A22, A25, } \\
\text { and A26. }\end{array}$ \\
\hline $\begin{array}{l}\text { 539. Uncertainty } \\
\text { in Extrapolated } \\
\text { Data to Higher } \\
\text { Temperatures in } \\
\text { RPV. }\end{array}$ & $\begin{array}{l}\text { Uncertainty in } \\
\text { Extrapolated Data to } \\
\text { Higher Temperatures. }\end{array}$ & $\begin{array}{l}\text { 6944-186. Creep (normal operations). } \\
\text { 6944-173. Thermal aging (long term). } \\
\text { 6944-174. Thermal aging (long term). } \\
\text { 6944-175. Thermal aging (short term, } \\
\text { high temperature). } \\
\text { 6944-176. Thermal aging (short term, } \\
\text { high temperature). }\end{array}$ & $\begin{array}{l}\text { Creep and thermal aging for } \\
\text { thick forgings are covered } \\
\text { by tests C1-C16. }\end{array}$ \\
\hline
\end{tabular}


Table 4. (continued).

\begin{tabular}{|llll|}
\hline \multicolumn{1}{|c}{ Risk Title } & \multicolumn{1}{c}{ Description } & \multicolumn{1}{c|}{ Associated PIRTs } & \multicolumn{1}{c|}{ Status } \\
\hline 510. Weldments & Additional data may be & 6944-188. Field fabrication process & Field fabrication process \\
and post weld & needed for the mechanical \\
heat treatment of & control. & properties of thick & 6944-189. Property control in heavy \\
Grade 91 steel. & $\begin{array}{l}\text { sections, where there is } \\
\text { the possibility of retained }\end{array}$ & sections. & $\begin{array}{l}\text { especially in the post weld } \\
\text { heat treatment area. }\end{array}$ \\
& $\begin{array}{l}\text { ferrite in this martensitic } \\
\text { steel, which can lead to } \\
\text { embrittlement. }\end{array}$ & & $\begin{array}{l}\text { Improved properties } \\
\text { database for weldments } \\
\text { from tests C1, C2, C3, C4, }\end{array}$ \\
\hline
\end{tabular}

\subsubsection{Technology Development Roadmap (NOAK)}

A TDRM for NGNP R\&D NOAK RPV is shown in Appendix A.

\subsubsection{System Summary}

The DDNs, risks and PIRTS are being addressed by the materials test program. There are however a number of gaps where a DDN or risk are not covered by the materials program.

There are no tests identified for the emissivity of SA508/533 and Grade 91 steel. Any oxidized steel has similar emissivity properties, therefore the thought being that there is no pressing need for tests at this time with the limited resources available. There are emissivity tests being performed at the University of Wisconsin under the NERI project, but not under the control of the INL.

There are no tests for the effects of irradiation on SA508/533 and Grade 91 steel (fractured and non fractured). The INL Materials program stance is that the irradiation effects are well known in the temperature range of light water reactor vessels. Although NGNP temperatures are expected to differ from light water reactor temperatures, the fluence is estimated to be roughly an order of magnitude less for the NGNP RPV. Therefore studies of irradiation effects on long-term creep and creep-fatigue are not planned at this time. 


\subsubsection{Intermediate Heat Exchanger}

The IHX accepts heat from the primary loop and transfers it to the secondary loop.

\subsubsection{IHX Design Description}

The IHX transfers heat between the primary heat transport system (PHTS) and the secondary heat transport system (SHTS). The PHTS is comprised of the primary piping, primary circulator, and primary helium working fluid. The SHTS is comprised of the secondary piping, secondary circulator, and secondary helium working fluid. Heat is also transferred by the IHX to downstream applications (e.g., power production [SG], and process heat).

The IHX is comprised of the following components:

- Heat exchanger cores and/or modules containing the heat transfer surface

- $\quad$ The IHX vessel

- Headers and/or piping that provide a transition between the heat exchanger cores and/or modules and the PHTS and SHTS piping

- Internal structures that provide for support (steady state, transients, and seismic loading) of the IHX and related internal components within the IHX vessel

- Thermal baffles and insulation.

\section{Functions Performed}

The primary functions of the IHX are to contain the primary and secondary helium coolants and to transport thermal energy, in the form of heat, from the reactor's PHTS to the SHTS working fluid. Secondary functions include providing a pressure boundary, insulating the vessel, and preventing cross contamination (secondary to primary or vice versa).

\subsubsection{Research and Development Test Plans}

The R\&D test plans focus on the codification and licensing issues related to the use of the primary alloy used for the IHX Alloy 617. The test references (A1-A28) are taken from Table 21 of PLN-2804, "Next Generation Nuclear Plant Steam Generator and Intermediate Heat Exchanger Materials Research and Development Plan," (Rev. 1, September 23, 2010).

\subsubsection{IHX Status}

The IHX is not currently included in the NGNP configuration, but will be included in follow on NOAK reactors.

INL and Westinghouse have assigned TRL-3 to the IHX. There is a significant amount of R\&D to generate sufficient information to incorporate Alloy 617 into the ASME BPV Code. In addition to the requirement for inclusion of Alloy 617 in the ASME BPV Code, it has been determined that additional studies of potential degradation of the properties of this material are needed because high temperature interaction with the anticipated NGNP helium environment is required.

Table 5. IHX TRL determination by each reactor supplier and INL.

\begin{tabular}{|ccccc|}
\hline System & AREVA & GA & Westinghouse & INL \\
\hline Intermediate heat exchanger & Not provided & Not provided & 3 & 3 \\
\hline
\end{tabular}




\subsubsection{Research and Development Tasks}

This section discusses the detailed plans to address the ASME BPV Code and NRC licensing issues related to Alloy 617. Incorporating Alloy 617 into Section III, Subsection NB and NH is one of the main goals for the draft Alloy 617 Code effort.

The sections below describe the main effects and properties of the materials to be tested. The sections describe what the purpose of the tests are, what the environmental conditions are. PLN-2804 provides further details on the testing conditions of the tests.

\section{Subsection NH Temperature Regime}

For temperatures above $427^{\circ} \mathrm{C}$, the appropriate values for time-independent allowable stress are under the jurisdiction of Subsection NH. A test matrix is required to accommodate any possible request for confirmatory tensile data from the Allowable Stresses Task Force:

\section{A1. Tensile Test Matrix for Confirmatory Testing.}

\section{Tests to Determine Weld Strength Rupture Factor for Alloy 617 Code Case}

The weld strength rupture factor (WSRF) is required in applying the creep-fatigue procedure in Subsection NH. WSRF is defined as the ratio of the creep-rupture strength of the weldment to that of the base metal. A test matrix is required to determine weld strength rupture factors:

Table A2. Test Matrix to Determine Weld Strength Rupture Factor.

\section{Assess Creep-Fatigue Procedure for Alloy 617 Welds}

Creep-fatigue data for Alloy 617 weldments are needed to assess the adequacy of the treatment of welds per the Subsection NH procedure under creep-fatigue conditions. From a licensing perspective, the availability of the creep-fatigue data for welds will help to address NRC's basic concerns about weldment creep crack growth, etc., to verify overall conservatism. Half of the specimens will be tested in air while the other half will be tested in a helium environment:

\section{A3. Creep-Fatigue Tests for Alloy 617 Welds.}

\section{Characterize Aging Effects on Fracture Toughness}

The formation of embrittling phases during long-term thermal exposure of Alloy 617 at a certain temperature range (below the intended steady-state operating temperature for IHX components) has a negative impact on toughness. A test matrix is required to establish fracture toughness to address NRC concerns:

A4(a). Aging Effects on Fracture Toughness of Alloy 617 Wrought Metal

A4(b). Aging Effects on Fracture Toughness of gas tungsten arc welding from Filler Metal 617.

\section{Strain Rate Change Tensile Tests}

Tensile tests are required to obtain data to determine the strain rate sensitivity of Alloy 617 to support the Unified Constitutive Model. A wide range of strain rates is sampled within a single test. The tests cover the full range of temperatures from room temperature to $1000^{\circ} \mathrm{C}$ :

A5. Tensile Test Matrix to Determine Strain Rate Sensitivity in Support of Unified Constitutive Model. 


\section{Strain Rate Change Torsion Tests}

These tests are designed to gather data on the strain rate sensitivity of Alloy 617 to support the Unified Constitutive Model:

A6. Torsion Test Matrix for Validating Von Mises Criterion to Support Unified Constitutive Model.

\section{Stress Dip Tests}

These tensile tests are designed to obtain data for determining the materials constants related to the internal variables. During the stress dip period, the test samples a wide range of inelastic strain rates:

A7. Stress Dip Test Matrix to Support Unified Constitutive Model.

\section{Short-term Creep Tests}

These tensile tests are designed to obtain data for determining the materials constants related to the internal variables:

A8. Test Matrix for Short-term (Days) Creep Tests to Support Unified Constitutive Model.

\section{Uniaxial Ratcheting}

These ratcheting tests are designed to obtain data for determining the materials constants related to the internal variables:

A9. Test Matrix for Uniaxial Ratcheting Tests to Support Unified Constitutive Model.

\section{Torsional Cycling with Constant Axial Strain}

These biaxial tests are designed to obtain data for determining the materials constants related to the internal variables:

A10. Test Matrix for Torsional Cycling with Constant Axial Strain to Support Unified Constitutive Model.

\section{Tensile Loading-Unloading-Creep Sequence}

These tensile tests are designed to obtain data for determining the materials constants related to the internal variables:

A11. - Test Matrix for Loading-Unloading-Creep Sequence to Support Unified Constitutive Model.

\section{Thermo-mechanical Cycling Tests}

Out-of-phase thermo-mechanical cycling tests are proposed to determine the non-isothermal response of Alloy 617:

A12. Test Matrix for Thermo-mechanical Cycling to Support Unified Constitutive Model.

\section{Creep and Relaxation Curves}

Longer term creep and stress relaxation responses are needed to qualify the long-term predictability of the unified constitutive model. To support the early need dates of the conceptual/preliminary design activities, data from the data log at four-month intervals will be used to calibrate/fine-tune the material constants of the unified constitutive equations for Alloy 617:

A13(a). Test Matrix for Creep Curves to Qualify Unified Constitutive Model. 


\section{Thermal Aging Effects}

The data will be used to determine the influence of thermal aging on the material constants of the unified constitutive model. This effort also addresses NRC concern that Alloy 617 undergoes thermal aging when exposed to elevated temperatures for long-time service:

A14. Uniaxial Tests on Thermally Aged Alloy 617 to Support Unified Constitutive Model.

\section{Model Tube Burst Tests - Alloy 617}

This will be a series of model tube burst tests to demonstrate the adequacy of the criteria and adjusted allowable stress values to address NRC concerns for (a) long-term thermal aging and (b) crack initiation and subcritical crack growth, respectively. These test results will also address NRC concern regarding weld integrity.

A15. Tube Burst Tests for Alloy 617 and Alloy $800 \mathrm{H}$

\section{Improve Alloy 617 Creep-Fatigue Procedure}

Elastic follow-up testing uses a simplified model of the structure to determine the cyclic life experimentally (Simplified Model Test [SMT] approach). A test matrix for generating creep-fatigue data using 40 SMT specimens:

A16. Creep-Fatigue Test Matrix for SMT Specimens ( $\mathrm{e} \Delta \varepsilon=$ elastically calculated strain range in percent).

\section{Long-term Creep}

To support ASME BPV Code acceptance, final design activities and final licensing approval, longterm creep-rupture tests at low-stress levels are required. A few very-long-term creep-rupture tests at prototypical operating stress levels should be initiated to provide creep rupture data:

A17. Long Term Alloy 617 Creep Rupture Tests for Qualification.

\section{Yield and Tensile Strength Reduction Factors}

For extended elevated temperature service, Subsection NH requires using yield and tensile strengthreduction factors that are functions of exposure time and exposure temperature to account for possible decrease in the yield and tensile strengths caused by thermal aging:

A18. Thermal Aging Test Matrix for Strength Reduction Factors.

\section{Fatigue Design Curves for Alloy 617 Code Case (Standard Grain Size)}

The continuous fatigue design curves are an integral part of the creep-fatigue procedure in Subsection $\mathrm{NH}$. At higher temperatures and lower strain rates, crack growth change from trans-granular to Intergranular, and there is a significant effect of strain rate. These tests will capture data for the design curves:

A19. Fatigue Tests to Support Design Curve Development in Alloy 617 Code Case.

\section{Creep-Fatigue Interaction Diagram for Alloy 617}

The creep-fatigue interaction diagram is an integral part of the creep-fatigue procedure of Subsection $\mathrm{NH}$. A test matrix for generating creep-fatigue data to support the determination of the creep-fatigue interaction diagram in the Alloy 617 Code Case will utilize 96 creep-fatigue specimens:

A20. Creep-fatigue Test Matrix to Support Determination of Creep-Fatigue Interaction Diagram. 


\section{Multiaxial Creep-rupture Failure Criterion for Alloy 617}

Creep-rupture data that support the creep-fatigue design procedure of Subsection NH are based on uniaxial testing. Structural components generally undergo multiaxial loading. In Subsection NH, an effective stress defined with respect to a multiaxial rupture strength Criterion 102 is used to relate the multiaxial stress state in a component determined by inelastic analysis to the uniaxial creep-rupture data:

A21. Test Matrix to Determine "C" Factor in Multiaxial Creep Rupture Strength Criterion for Alloy 617.

\section{Microstructural Determination of the Onset of Tertiary Creep}

Information is needed on whether the gradually increasing creep curve is a manifestation of different deformation mechanisms typified by dislocation generation and motion, or if it corresponds to creep damage such as grain boundary cavitation and cracking reminiscent of those occurring in the classical tertiary creep regime:

A22. Test Matrix for Interrupted Creep Tests.

\section{Fatigue with Hold Time for Alloy 617}

A critical issue of whether the creep-fatigue behavior of Alloy 617 saturates with increasing hold time. In this context, saturation means that the number of cycles to failure is no longer increasing, as the hold time increases (or increasing very little). A test matrix is required to clarify this issue.

A23. Test Matrix to Address Creep-Fatigue Saturation with Hold Time.

\section{Assessment of Diffusional Creep for Alloy 617}

The creep mechanisms for Alloy 617 at very high temperatures and low-stress can be explored using the creep test plan matrix. The data from this testing will be analyzed to determine the stress exponents, activation energies, and operative creep mechanisms:

A24. Test Matrix to Explore Creep Mechanisms of Alloy 617.

\section{Creep-rupture Tests to Develop Grain Size Rupture Factors}

This test matrix supports the determination of the grain size rupture factors. The test temperatures are 800,900 , and $1000^{\circ} \mathrm{C}$ :

\section{A25. Test Matrix for Determining Grain Size Rupture Factors for Alloy 617.}

\subsubsection{Design Data Needs}

The DDNs for the IHX are focused around the material properties of Alloy 617. Several DDNs associated with the technological development of the NGNP IHX are described in Table 6 . The test references A1-A28 are taken from Table 21 of PLN-2804. The first three column references are from DDN documents (see 'References' section, numbers 15, 16 and 17). 
Table 6. IHX DDNs.

\begin{tabular}{|c|c|c|c|}
\hline Number & Vendor & Description & Status \\
\hline 2.2.2.1 & AREVA & $\begin{array}{l}\text { IHX Materials - Baseline mechanical property } \\
\text { data, including creep-fatigue data. }\end{array}$ & $\begin{array}{l}\text { The data need is covered by } \\
\text { tests } \mathrm{A} 3, \mathrm{~A} 16, \mathrm{~A} 20 \text {. }\end{array}$ \\
\hline N.13.02.01 & GA & $\begin{array}{l}\text { Effects of Primary Helium and Temperature } \\
\text { on IHX Materials. }\end{array}$ & $\begin{array}{l}\text { The data need is covered by } \\
\text { tests } A 3, A 19, A 20 \text {. }\end{array}$ \\
\hline HPS-ELE-07 & WEC & $\begin{array}{l}\text { Test Alloy } 230 \text { and Alloy } 617 \text { in High } \\
\text { Temperature Helium and Air/Oxygen and } \\
\text { Steam/Hydrogen Mixtures. }\end{array}$ & $\begin{array}{l}\text { The data need is covered by } \\
\text { tests A3, A19, A } 20 \text { Just for } 617 \\
\text { and not for steam/hydrogen. }\end{array}$ \\
\hline HTS-01-02 & WEC & $\begin{array}{l}\text { Thermal/Physical and Mechanical Properties } \\
\text { of Alloy } 617 \text {. }\end{array}$ & $\begin{array}{l}\text { The data need is covered by } \\
\text { tests A18. }\end{array}$ \\
\hline HTS-01-04 & WEC & Aging Effects Of Alloy 617. & $\begin{array}{l}\text { The data need is covered by } \\
\text { tests } \mathrm{A} 4 \mathrm{a}, \mathrm{A} 4 \mathrm{~b}, \mathrm{~A} 14, \mathrm{~A} 18 \text {. }\end{array}$ \\
\hline HTS-01-05 & WEC & $\begin{array}{l}\text { Environmental Effects of Impure Helium on } \\
\text { Alloy } 617 .\end{array}$ & $\begin{array}{l}\text { The data need is covered by } \\
\text { tests A3, A19, A } 20 \text {. }\end{array}$ \\
\hline HTS-01-06 & WEC & Grain size assessment of Alloy 617. & $\begin{array}{l}\text { The data need is covered by } \\
\text { tests } A 25, \mathrm{~A} 28 \text {. }\end{array}$ \\
\hline HTS-01-21 & WEC & Corrosion allowances for Alloy 617. & $\begin{array}{l}\text { The data need is covered by } \\
\text { tests } \mathrm{A} 3, \mathrm{~A} 19, \mathrm{~A} 20 \text {. }\end{array}$ \\
\hline HTS-01-03 & WEC & $\begin{array}{l}\text { Welding and as-welded properties of materials } \\
\text { of Alloy } 617 \text { for compact heat exchangers. }\end{array}$ & No tests identified. \\
\hline HTS-01-20 & WEC & $\begin{array}{l}\text { Influence of section thickness on materials } \\
\text { properties of Alloy } 617 .\end{array}$ & $\begin{array}{l}\text { A scoping study was } \\
\text { recommended in the R\&D test } \\
\text { plans for the IHX. }\end{array}$ \\
\hline
\end{tabular}

\subsubsection{Additional Technological Development}

The R\&D materials test plans recommend further development of Alloy 617. Currently for the work identified in this section there are no test plans or any existing programs in place to perform these activities.

This section identifies some programs that are being proposed to be performed but there is no specific test plan identified for this work. There is also no schedule identified for these activities. These are effectively follow-on activities to be performed at a later date.

\section{Scoping Study for Creep-rupture Strength of Alloy 617 Foils}

Accelerated creep-rupture tests on foils with different grain sizes need to be initiated as soon as possible. The resulting creep-rupture times from small grain-sized specimens are to be compared with those from standard grain-sized specimens under the same temperature and stress conditions. Based on these data, if a sufficient performance envelope exists and the creep deformation mechanism is similar to the standard grain-sized product forms, steps will be taken to support ASME BPV Code material qualification.

\section{Define adequate bonds}

A test program must be developed to determine mechanical properties of the diffusion bonds or brazed joints. It must also be verified that the environmental effects in the joined regions are similar to the 
base metal, that the microstructure is stable with no chemical in-homogeneity, and that the grain size is acceptable.

\section{Environmentally Assisted Cracking}

Experiments must be designed to test materials and components in gas representative of the NGNP gas. The chemical composition, including anticipated impurities and moisture levels, pressure $(\sim 7 \mathrm{MPa})$, and velocities up to $75 \mathrm{~m} / \mathrm{s}$ must all be accounted for. Under these conditions, there is an increased potential for erosion. This effort will be coordinated with the NGNP Heat Transport System Components Engineering Test Plan.

\section{Key Feature Testing}

Key feature testing is a way to bridge the gap between structural performance prediction by design methods, which are established based on specimen testing, and the actual structural performance of the component as determined from component testing or actual service.

\section{Vessel and Piping Ratcheting Tests for Alloy 617 and Alloy 800H}

These tests address NRC concerns on whether the current simplified bounding methods in ASME BPV code, Subsection NH, Appendix T are appropriate for both the geometry and conditions for which they were derived, a pressurized cylinder with cyclic linear through-the-wall thermal gradients, and the more general geometries and loading conditions for which they are currently permitted.

\subsubsection{Risk Analysis and PIRT}

The NGNP risks database (NGNP_RMS_V2_D_15SEP2010.mdb) identifies a number of risks and PIRTs associated with the IHX. Table $\overline{7}$ identifies how those risks are mitigated by the Materials R\&D test plans. The test references given in Table 7 for A1-A31 are taken from Table 21 of PLN-2804.

Table 7. IHX Risk and PIRT analysis.

\begin{tabular}{|c|c|c|c|}
\hline Risk Title & Description & Associated PIRTs & Status \\
\hline $\begin{array}{l}\text { 446. Contaminant } \\
\text { Effects on Material } \\
\text { Properties. }\end{array}$ & $\begin{array}{l}\text { The codes and code cases do not } \\
\text { provide specific guidelines for } \\
\text { environmental effects, } \\
\text { especially the effect of impure } \\
\text { helium on the high temperature } \\
\text { behavior (e.g., fatigue, creep, } \\
\text { and creep-fatigue) of the } \\
\text { materials considered. }\end{array}$ & $\begin{array}{l}\text { 6944-211. Water or } \\
\text { chemical ingress/attack. }\end{array}$ & $\begin{array}{l}\text { Impure helium effects addressed } \\
\text { by tests A3, A19, and A20 for } \\
\text { Alloy } 617 .\end{array}$ \\
\hline $\begin{array}{l}\text { 444. Design and } \\
\text { Material Stresses } \\
\text { for IHX. }\end{array}$ & $\begin{array}{l}\text { Early design and model testing } \\
\text { may be required to confirm the } \\
\text { feasibility of selected methods. }\end{array}$ & $\begin{array}{l}\text { 6944-318. System, } \\
\text { Subsystem/Structure, } \\
\text { Component, Stress on IHX } \\
\text { or Other Component in } \\
\text { Contact with Balance-of- } \\
\text { Plant (BOP) Generic Power } \\
\text { or Thermal Transients } \\
\text { Initiated in VHTR Events } \\
\text { that Impact Chemical Plant. }\end{array}$ & $\begin{array}{l}\text { Stress and environmental tests } \\
\text { on Alloy } 617 \text { covered by tests } \\
\text { A1-A31. }\end{array}$ \\
\hline $\begin{array}{l}\text { 448. Difficult to } \\
\text { perform all tests on } \\
\text { Alloys } 617 \text { and } \\
230 .\end{array}$ & $\begin{array}{l}\text { Alloys } 617 \text { and } 230 \text { in all } \\
\text { product forms and grain sizes } \\
\text { may be cost prohibitive and } \\
\text { adds unnecessary burden on } \\
\text { R\&D activities and budgets. }\end{array}$ & $\begin{array}{l}\text { 6944-209. Manufacturing } \\
\text { phenomena (such as } \\
\text { joining). }\end{array}$ & $\begin{array}{l}\text { A comprehensive set of tests } \\
\text { with multiple grain sizes are } \\
\text { proposed in the test plan from } \\
\text { A1-A31. }\end{array}$ \\
\hline
\end{tabular}


Table 7. (continued).

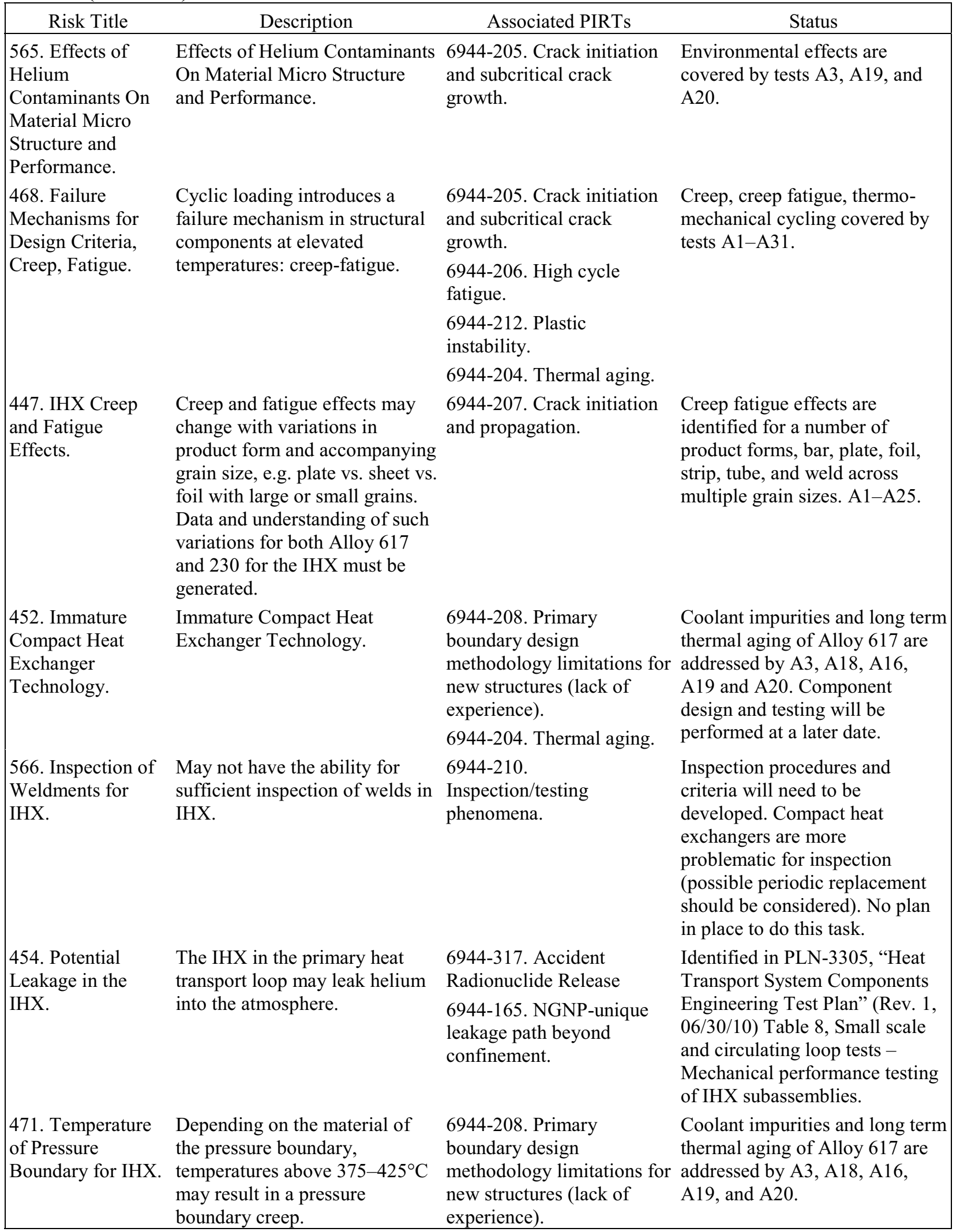


Table 7. (continued).

\begin{tabular}{|c|c|c|c|}
\hline Risk Title & Description & Associated PIRTs & Status \\
\hline $\begin{array}{l}\text { 473. Temperature } \\
\text { of Pressure } \\
\text { Boundary for IHX. }\end{array}$ & $\begin{array}{l}\text { Migration of tritium from the } \\
\text { primary system may cause } \\
\text { spread of contamination of the } \\
\text { secondary and tertiary systems. }\end{array}$ & $\begin{array}{l}\text { 6944-315. Diffusion of } 3 \mathrm{H} \text {. } \\
\text { 6944-316. Diffusion of } 3 \mathrm{H} \text {. }\end{array}$ & $\begin{array}{l}\text { The migration of tritium is being } \\
\text { investigated under PLN-3479, } \\
\text { "R\&D Test Control Plan - High } \\
\text { Temperature Hydrogen } \\
\text { Permeation through Nickel } \\
\text { Alloys" (Rev. 0, 4/19/2010). The } \\
\text { permeation tests are performed } \\
\text { at the Safety and Tritium } \\
\text { Applied Research (STAR) } \\
\text { Facility at the Advanced Test } \\
\text { Reactor (ATR) Complex. }\end{array}$ \\
\hline $\begin{array}{l}\text { 470. Uncertainty in } \\
\text { Extrapolated Data } \\
\text { to Higher } \\
\text { Temperatures in } \\
\text { IHX. }\end{array}$ & $\begin{array}{l}\text { The risk is associated with the } \\
\text { uncertainty in extrapolation of } \\
\text { existing data to higher } \\
\text { temperatures. }\end{array}$ & $\begin{array}{l}\text { 6944-212. Plastic } \\
\text { instability. }\end{array}$ & $\begin{array}{l}\text { Coolant impurities and long term } \\
\text { thermal aging of Alloy } 617 \text { are } \\
\text { addressed by A3, A18, A16, } \\
\text { A19, and A20. }\end{array}$ \\
\hline $\begin{array}{l}\text { 481. Verification \& } \\
\text { Validation (V\&V) } \\
\text { of IHX Analytical } \\
\text { Methods to } \\
\text { Support Design } \\
\text { Development. }\end{array}$ & $\begin{array}{l}\text { V\&V of analytical methods may } \\
\text { be required to support design } \\
\text { development, ASME BPV code } \\
\text { acceptance, ASTM International } \\
\text { standards acceptance, and NRC } \\
\text { licensing. The inability to } \\
\text { simulate anticipated operational } \\
\text { or off-normal plant behaviors } \\
\text { may impede licensing. }\end{array}$ & $\begin{array}{l}\text { 6944-308. Harmonics. } \\
\text { 6944-314. Loss of Heat } \\
\text { Sink Cooling, then no Heat } \\
\text { Sink IHX Hydrodynamic } \\
\text { Loading. }\end{array}$ & $\begin{array}{l}\text { Identified modeling required } \\
\text { using RELAP5 and ASPEN in } \\
\text { PLN-2498, "Methods Technical } \\
\text { Plan" (Rev. 2, 09/27/10). }\end{array}$ \\
\hline
\end{tabular}

\subsubsection{Technology Development Roadmap}

A TDRM for NGNP R\&D IHX is shown in Appendix A.

\subsubsection{System Summary}

There are a few gaps where a DDN or risk are not covered by the materials program related to materials for use by the IHX

There are no tests for welding and weld properties of Alloy 617 or for the influence of section thickness on the material properties for 617. Currently there is no provision in the ASME BPV code for diffusion bonding or brazing, no tests are planned pending standardization and codification in this area.

There is a risk identified related to the inspection of weldments for the IHX. There are currently no test plans from a materials perspective related to this risk. This is to be expected since the materials program is focused on the properties of the building materials for the IHX and not the design.

\subsubsection{Steam Generator}

The SG converts water into steam using heat from a heat source, in this case heat produced in a nuclear reactor core. Pressurized water is channeled through alloy tubes, which heats up water around the tube to form the steam. 


\subsubsection{Steam Generator Design Description}

In the SG, subcooled feedwater acquires heat from the higher temperature helium circulating in the PHTS and vaporizes, becoming superheated steam. Piping transports the steam to the turbine inlet to drive the turbine rotation or it can be directed for use as process heat. The SG design concept is a directcycle helical tube. It is a vertically oriented, counter-flow, shell-and-tube, once-through, nonreheat tubular heat exchanger with helium on the shell side and water/steam in the tubes. The SG may interface with the secondary heat exchanger and power conversion system. Internal structure materials (tube supports, tube surfaces, shrouds, etc.) are selected consistent with their respective operating temperatures. The SG incorporates an economizer, evaporator, and first-stage superheater in one helical tube bundle, followed by a finishing superheater in a second helical tube bundle.

\section{Functions Performed}

The function of the SG is to produce superheated, high-pressure steam for conversion into mechanical work to turn a turbine that will generate electricity. The steam can also be directed through piping such that it can be used as process heat in industrial applications.

\subsubsection{Research and Development Test Plans}

The R\&D test plans are focused on the codification and licensing issues related to the usage of the primary alloy used for the SG Alloy $800 \mathrm{H}$. Test references A1-A28 are taken from Table 21 of PLN2804.

\subsubsection{Steam Generator Status}

The SG has been assigned a TRL-6 by GA, primarily because Fort St. Vrain experience has demonstrated the basic helical coil SG thermal and hydraulic design and the SG material selections. In addition, a high level of SG design definition is already available from the cancelled MHTGR project. Both AREVA and Westinghouse believe that past experience justifies a TR-6. INL has assigned TRL-4 to the SG because there are still licensing and codification issues for Alloy $800 \mathrm{H}$ some of which are tensile strength because of thermal aging, extended allowable stresses to 500,000 hours service time. Material properties testing will also be needed to investigate the performance of the bimetallic weld between the Alloy $800 \mathrm{H}$ and $2.25 \mathrm{Cr} 1 \mathrm{Mo}$ tubes. Table 8 summarizes TRL determinations for SG.

Table 8. Steam generator TRL determination by each reactor supplier and INL.

\begin{tabular}{|lcccc|}
\hline $\begin{array}{c}\text { Heat Transport System structure, } \\
\text { system, and component }\end{array}$ & AREVA & GA & Westinghouse & INL \\
\hline Steam generator & 6 & $6^{\text {a }}$ & 6 & 4 \\
\hline & & & & \\
a. $\quad \begin{array}{l}\text { General Atomics Conceptual Design Report - Steam cycle Modular Helium reactor (SC-MHR) Demonstration Plant } \\
\text { (NGNP-R00016 Revision 0) }\end{array}$ \\
\hline
\end{tabular}

\subsubsection{Research and Development Tasks}

This section discusses the detailed plans to address the code issues that support the development of the NGNP SG. It describes the main effects and properties of the materials to be tested, the purpose of the tests, the environmental conditions. For further details on the testing conditions of the tests refer to PLN2804. 


\section{Model Tube Burst Tests}

A series of model tube burst tests are needed to demonstrate the adequacy of allowable stress values to address NRC concerns for (a) long-term thermal aging and (b) crack initiation and subcritical crack growth. These test results will also address NRC concern regarding weld integrity:

A15. Tube Burst Tests for Alloy $800 \mathrm{H}$.

\section{Unified Constitutive Model}

To develop the unified constitutive equations for Alloy $800 \mathrm{H}$, appropriate data is required to determine the material constants of the model. Many tests have been carried out for Alloy $800 \mathrm{H}$ since the 1970s and creep information needed for unified constitutive model development could be synthesized from open literature sources. However, tensile data that would allow some of the material constants in the unified constitutive equations to be determined are not available. The tensile tests proposed include strainrate change, stress dip, and loading/unloading/creep at a stress:

A26. Tensile Tests Supporting Unified Constitutive Model for Alloy 800H.

\section{Alloy 800H Weldments}

Based on the ASME Standards Technology, LLC/DOE Generation IV Reactor Materials Project recommendation, a test plan is proposed to generate creep-rupture data for Alloy $800 \mathrm{H}$ weldments to support extending the time and temperature limits of Alloy 800H WSRF in ASME BPV Code, Section III, Division 1, Subsection NH:

A27. Test Matrix for Weld Strength Rupture Factor for Alloy 800H Weldments.

\section{Strain Rate Effect on Yield and Tensile Strengths}

Currently, Alloy $800 \mathrm{H}$ is approved for construction to $760^{\circ} \mathrm{C}$, the ASME Standards Technology, LLC/DOE Generation IV Reactor Materials Project was charged to consider extending the applicable temperature range for Alloy $800 \mathrm{H}$ to $900^{\circ} \mathrm{C}$. Average and minimum stresses were determined and recommended for ASME BPV Code action. To better understand the range of applicability of the recommended values, further testing at various strain rates is needed:

A28. Test Matrix for Strain Rate Effect on Yield and Tensile Strengths for Alloy 800H.

\section{Effects of Diffusional Creep Mechanism on Allowable Stresses}

Diffusional creep mechanisms are active in Alloy $800 \mathrm{H}$ at $800^{\circ} \mathrm{C}$ and higher at stresses typical of long time service. Some testing of Alloy $800 \mathrm{H}$ is needed to clearly establish the temperature, stress, and grain size dependency of the early creep process at temperatures above $800^{\circ} \mathrm{C}$ :

A29. Test Matrix to Explore Creep Mechanisms of Alloy $800 \mathrm{H}$.

\section{Yield and Tensile Strength Reduction Factor}

Thermal aging is not a significant concern within the specified temperature limit of $760^{\circ} \mathrm{C}$ for Alloy $800 \mathrm{H}$. Yield and tensile strength reduction factors are required for service temperatures greater than $730^{\circ} \mathrm{C}$ in ASME BPV Code, Section III, Division 1, Subsection NH. These factors are valid up to 300,000 hours. Extension of these factors to 500,000 hours is required to support the NGNP intermediate temperature IHX and core internal application:

A30. Test Matrix to Qualify Yield and Tensile Strength Reduction Factors for Alloy 800H Due to Thermal Aging. 


\section{Effect of Multiaxial Stress State on Creep-Fatigue Procedure}

The "C" factor in the multiaxial creep-rupture strength criterion has a value of $\mathrm{C}=0$ for Alloy $800 \mathrm{H}$ in ASME BPV Code, Section III, Division 1, Subsection NH. Biaxial creep-rupture tests are required to validate the value of $\mathrm{C}=0$ for Alloy $800 \mathrm{H}$ :

A31 Test Matrix to Validate "C" Factor in Multiaxial Creep Rupture Strength Criterion for Alloy $800 \mathrm{H}$.

\subsubsection{Design Data Needs}

The DDNs for the SG described in Table 9 are focused around the material properties of Alloy $800 \mathrm{H}$. The DDNs for Alloy $800 \mathrm{H}$ have been addressed in the R\&D test plans (or from previous work performed on Alloy $800 \mathrm{H}$ ). The first three column references are from DDN documents (see 'References' section, numbers 15,16 and 17).

Table 9. Steam generator DDNs.

\begin{tabular}{|c|c|c|c|}
\hline Number & Vendor & Description & Status (covered by tests) \\
\hline 2.2.3.1a & AREVA & Thermal Properties of Alloy $800 \mathrm{H}$. & $\begin{array}{l}\text { The data need is covered by test } \\
\text { A26. }\end{array}$ \\
\hline M.21.02.03 & GA & $\begin{array}{l}\text { Determine Properties of Alloy } 800 \mathrm{H} \text { Base } \\
\text { Metal and Weldments. }\end{array}$ & $\begin{array}{l}\text { The data need is covered by tests } \\
\text { A } 22 \text { and A } 27 .\end{array}$ \\
\hline M.21.02.02 & GA & $\begin{array}{l}\text { Determine Properties of } 2.25 \mathrm{Cr} 1 \mathrm{Mo} \text { Base } \\
\text { Metal and Weldment }\end{array}$ & No tests identified. \\
\hline HTS-01-25 & WEC & $\begin{array}{l}\text { Effects of aging on the properties of Alloy } \\
800 \mathrm{H} \text { and Hastelloy X. }\end{array}$ & $\begin{array}{l}\text { The data need is covered by test } \\
\text { A30 but not for Hastelloy X. }\end{array}$ \\
\hline HTS-01-27 & WEC & $\begin{array}{l}\text { Influence of grain size on material properties of } \\
\text { Alloy } 800 \mathrm{H} \text { and Hastelloy X. }\end{array}$ & $\begin{array}{l}\text { The data need is covered by test } \\
\text { A } 28 \text { but not for Hastelloy X. }\end{array}$ \\
\hline 2.2.3.1e & AREVA & $\begin{array}{l}\text { Irradiation Effects on Alloy } 800 \mathrm{H} \text { in a HTGR } \\
\text { Environment. }\end{array}$ & No tests identified. \\
\hline 2.2.3.1g & AREVA & $\begin{array}{l}\text { Material Properties of Alloy } 800 \mathrm{H} \text { in a HTGR } \\
\text { Environment up to }\left[1000^{\circ} \mathrm{C}\right] .\end{array}$ & No tests identified. \\
\hline 3.1.6.0a & AREVA & $\begin{array}{l}\text { Steam Generator-Integrity Testing of } \\
\text { Dissimilar Material Welding Joint in Tubes. }\end{array}$ & $\begin{array}{l}\text { A scoping study has been } \\
\text { recommended by the INL in the } \\
\text { referenced test plan. }\end{array}$ \\
\hline HTS-01-24 & WEC & $\begin{array}{l}\text { Effects of joining techniques on the properties } \\
\text { of Alloy } 800 \mathrm{H} \text { and Hastelloy X. }\end{array}$ & $\begin{array}{l}\text { A scoping study has been } \\
\text { recommended by INL in the } \\
\text { referenced test plan. }\end{array}$ \\
\hline HTS-01-26 & WEC & $\begin{array}{l}\text { Effects of exposure in impure helium on Alloy } \\
800 \mathrm{H} \text { and Hastelloy X weldment properties. }\end{array}$ & No tests identified. \\
\hline HTS-01-28 & WEC & $\begin{array}{l}\text { Influence Of Section Thickness On Material } \\
\text { Properties Of Alloy } 800 \mathrm{H} \text { and Hastelloy X. }\end{array}$ & No tests identified. \\
\hline SG-01-01 & WEC & $\begin{array}{l}\text { Secondary Side Corrosion Characteristics } \\
\text { Alloy } 800 \mathrm{H} \text { and } 2.25 \mathrm{Cr} 1 \mathrm{Mo} \text { and Weldments }\end{array}$ & $\begin{array}{l}\text { The secondary side environment } \\
\text { is not well established making } \\
\text { test definition difficult until the } \\
\text { design is known. No tests } \\
\text { identified }\end{array}$ \\
\hline SG-01-02 & WEC & Helium Environment Effects on $2.25 \mathrm{Cr} 1 \mathrm{Mo}$ & No tests identified \\
\hline
\end{tabular}




\subsubsection{Additional Technological Development}

The R\&D materials test plans recommend further development of Alloy $800 \mathrm{H}$. This section identifies some programs that are being proposed to be performed but there is no specific test plan identified for this work. There is also no schedule identified for these activities since they are effectively follow-on activities to be performed at a later date.

\section{Vessel and Piping Ratcheting Tests-Alloy $800 \mathrm{H}$}

These tests address NRC concerns on whether the current simplified bounding methods in Appendix T of Subsection NH are appropriate for not only the geometry and conditions for which they were derived, but also for the more general geometries and loading conditions for which they are currently permitted. Part of this task is to assess those tests for applicability to NGNP. An issue not addressed in previous testing is the effect of strain rate-dependent yield strength at high to very high temperatures on creep ratcheting models.

\section{More General Simplified Methods}

This is in the nature of generic issues for all of Subsection NH. New work on Task 9 of the ASME Standards Technology, LLC/DOE Generation IV Reactor Materials Project will address this issue. Recommended testing from the task will be assessed and tests relevant to NGNP will be proposed.

\section{Cold Work Effect and Subsequent Heat Treatment Requirements}

The Alloy $800 \mathrm{H}$ time-temperature curve that governs short-term temperature excursion beyond the maximum allowable temperature for the purpose of heat treatment needs to be extended to 500,000 hours. Research will be performed into how the original curve for up to 300,000 hours was created. Additional tests will be proposed in the future if it is determined that testing is necessary to support the extension of the time-temperature curve. Prohibiting cold work for service beyond 300,000 hours is an option under consideration.

\subsubsection{Risk Analysis and PIRT}

The NGNP Risks database (NGNP_RMS_V2_D_15SEP2010.mdb) identifies a number of risks and PIRTs associated with the SG. Table 10 identifies how those risks are mitigated by PLN-2804 (referenced tests A1-A31 are taken from Table 21 of PLN-2804). 
Table 10. Steam generator risk and PIRT analysis.

\begin{tabular}{|l|l|l|l|}
\hline \multicolumn{1}{|c|}{ Risk Title } & \multicolumn{1}{c|}{ Description } & \multicolumn{1}{c|}{ Associated PIRTs } & \multicolumn{1}{c|}{ Status } \\
\hline $\begin{array}{l}\text { 600. Failure } \\
\text { Mechanisms for } \\
\text { Creep, Fatigne. }\end{array}$ & $\begin{array}{l}\text { Failure Mechanisms } \\
\text { for Design Criteria, } \\
\text { Creep, Fatigue. }\end{array}$ & $\begin{array}{l}\text { 6944-194. Creep, creep crack } \\
\text { growth, thermal loading, } \\
\text { rotational stress, fatigue, creep } \\
\text { fatigue. } \\
\text { 6944-193. Missile (disc } \\
\text { failure). }\end{array}$ & $\begin{array}{l}\text { Identified creep and creep } \\
\text { fatigue tests for Alloy 800H } \\
\text { in A15, A26, A27, A29, and } \\
\text { A30. }\end{array}$ \\
\hline $\begin{array}{l}\text { 606. Fouling or } \\
\text { Plugging in SG. }\end{array}$ & $\begin{array}{l}\text { Fouling or Plugging } \\
\text { in SG. }\end{array}$ & $\begin{array}{l}\text { 6944-125. Fouling or plugging } \\
\text { plate-out and dust distribution } \\
\text { under normal operation. }\end{array}$ & $\begin{array}{l}\text { No fouling tests are identified } \\
\text { in the Materials test plans. }\end{array}$ \\
\hline $\begin{array}{l}\text { 600. Failure } \\
\text { Mechanisms for } \\
\text { Design Criteria, } \\
\text { Creep, Fatigue. }\end{array}$ & $\begin{array}{l}\text { Failure Mechanisms } \\
\text { for Design Criteria, } \\
\text { Creep, Fatigue. }\end{array}$ & $\begin{array}{l}\text { 6944-194. Creep, creep crack } \\
\text { growth, thermal loading, } \\
\text { rotational stress, fatigue, creep } \\
\text { fatigue. } \\
\text { 6944-193. Missile (disc } \\
\text { failure). }\end{array}$ & $\begin{array}{l}\text { Identified creep and creep } \\
\text { fatigue tests for Alloy 800H } \\
\text { in A15, A26, A27, A29, and } \\
\text { A30. }\end{array}$ \\
\hline $\begin{array}{l}\text { 529. Product Steam } \\
\text { Contamination } \\
\text { including Tritium } \\
\text { Migration). }\end{array}$ & $\begin{array}{l}\text { There may be } \\
\text { potential } \\
\text { contamination of the } \\
\text { product streams, } \\
\text { which may exceed } \\
\text { the acceptable limits } \\
\text { of contamination. }\end{array}$ & $\begin{array}{l}\text { 6944-125. Fouling or plugging } \\
\text { plate-out and dust distribution } \\
\text { under normal operation. }\end{array}$ & $\begin{array}{l}\text { The migration of tritium is } \\
\text { being investigated under } \\
\text { PLN-3479, "R\&D Test } \\
\text { Control Plan-High } \\
\text { Temperature Hydrogen } \\
\text { Permeation through Nickel } \\
\text { Alloys" (Rev. 0, April, 19, } \\
\text { 2010). The permeation tests } \\
\text { are performed at the STAR } \\
\text { Facility at the ATR Complex. }\end{array}$ \\
\hline
\end{tabular}

\subsubsection{Technology Development Roadmap (FOAK)}

A TDRM for NGNP R\&D SG is shown in Appendix A.

\subsubsection{Section Summary}

There are a number of gaps where a DDN or risk are not covered by the materials program related to the materials for the Steam Generator.

There are no tests related to the irradiation effects or material properties of Alloy $800 \mathrm{H}$ in an HTGR environment. However there are plans to develop an irradiation effects test plan specific to Alloy $800 \mathrm{H}$ as funds become available. There are also no tests related to the corrosion characteristics and influence of section thickness on material properties for Alloy $800 \mathrm{H}$, but there is a lot of data available on material properties for Alloy $800 \mathrm{H}$ from the German AVR/THTR program. There are a number of DDNs related to Hastelloy $\mathrm{X}$ and $2.25 \mathrm{Cr} 1 \mathrm{Mo}$, these materials are not included in the materials test program. When reactor vendor selection is made and the reactor design is established then these materials may be included as part of the Materials test plan program.

There is a risk related to the Steam Generator regarding fouling or plugging. There are no tests related to this risk in the materials program, which is to be expected as the material program is focused on the properties of the building materials for the Steam Generator and not the design. 


\subsection{Fuels}

The Fuels program is to provide a fuel qualification data set in support of the licensing and operation of the NGNP. Gas-cooled reactor fuel performance demonstration and qualification comprise the longest duration R\&D task required for NGNP design and licensing. The fuel form is to be demonstrated and qualified for service conditions enveloping normal operation and accidents.

\subsubsection{Fuels Description}

A major goal of the Advanced Gas Reactor (AGR) Fuel Development and Qualification Program is to establish coated particle fuel fabrication technology in the United States for the very high temperature reactor (VHTR) that is capable of producing TRISO fuel of a quality at least as good as that produced by German fuel technology. The AGR program is used as a basis for the TRLs for the NGNP Fuel Elements.

\section{Functions Performed}

The function performed by the fuel elements is to provide fissile fuel material for the fission reaction.

\subsubsection{Research and Development Test Plans for Fuel}

The overall goals for the Fuels R\&D test plans are to provide a fuel qualification data set in support of the licensing and operation of the NGNP. The fuel is to be demonstrated and qualified for service conditions enveloping normal operation and accident conditions. This fuel qualification effort is to support NRC in its preapplication review of the NGNP concept and to support the NRC in its eventual issuance of a license.

The TRISO-coated UCO (uranium oxycarbide) fuel particle shown in Figure 3 was chosen as the baseline fuel to be fabricated and tested in this program. The AGR-1 irradiation experiment used only UCO fuel in the fuel particle kernel. The AGR-2 irradiation experiment includes both $\mathrm{UCO}$ and $\mathrm{UO}_{2}$ (uranium dioxide) fuel particles. All future AGR irradiation experiments are currently planned to include only UCO fuel. If a pebble bed reactor (PBR) design should be developed for the NGNP, UCO fuel could be compacted into spherical elements to fit this design, although variations in particle design and qualification service conditions may be needed for optimal performance.

The R\&D NGNP fuel development and qualification program consists of five program elements:

- Fuel Fabrication

- Fuel and Materials Irradiation

- Post-Irradiation Examination (PIE) and Safety Testing

- Fuel Performance Modeling

- Fission Product Transport and Source Term. 


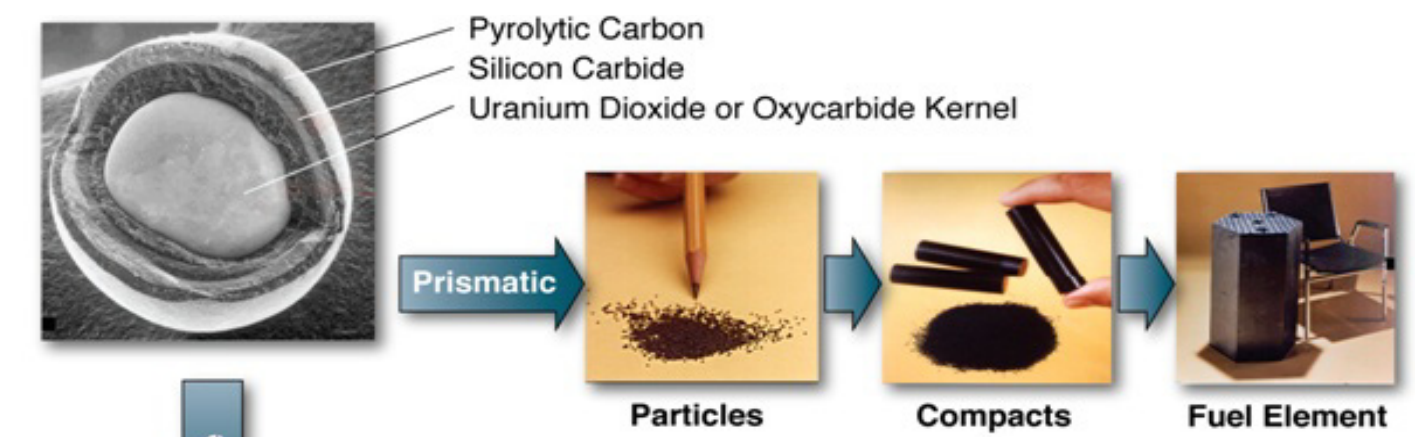

TRISO-coated fuel particles (left) are formed into fuel compacts (center) and inserted into graphite fuel elements (right) for the prismatic reactor
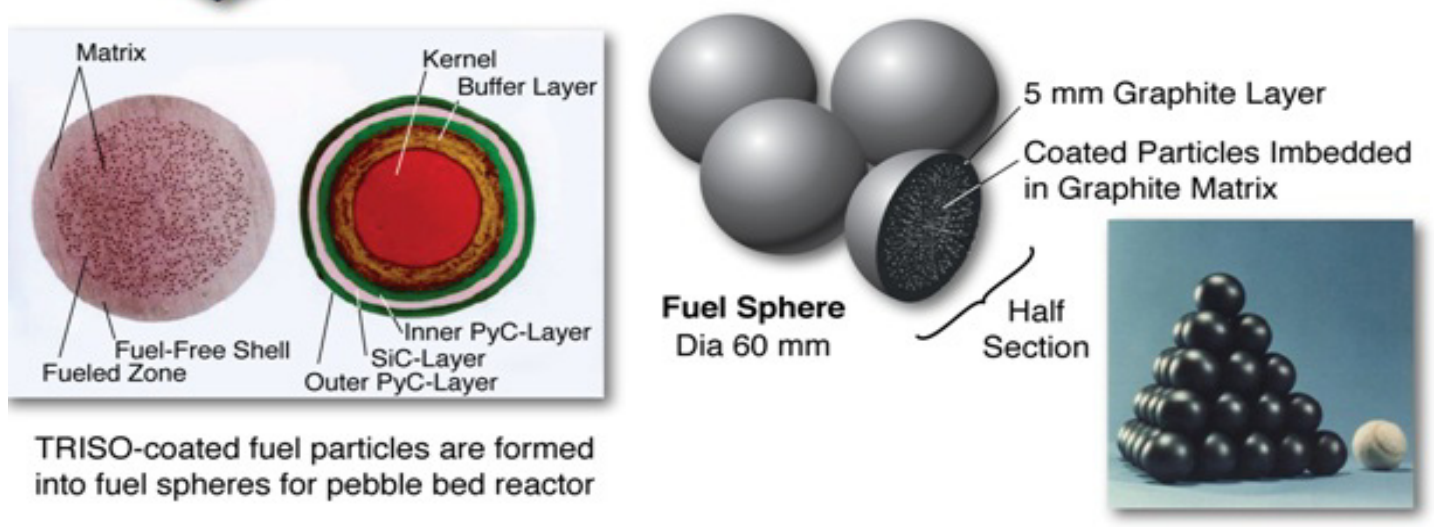

Figure 3. TRISO particle fuel element.

\subsubsection{Fuel status}

The Prismatic and Pebble-Bed fuel elements are currently rated as a TRL 5. There are too many uncertain and untested parameters with the current generation of fuel to attribute the Westinghouse suggested rating of TRL-7.

Table 11. Fuel TRL determination by each reactor supplier and INL.

\begin{tabular}{|c|c|c|c|c|c|}
\hline & System & AREVA & GA & Westinghouse & INL \\
\hline \multicolumn{2}{|r|}{ Fuel } & Not provided & 4 & $7^{\mathrm{a}}$ & 5 \\
\hline & $\begin{array}{l}\text { The TRL-7 wa } \\
\text { which is now }\end{array}$ & $\begin{array}{l}\text { e PBR design wl } \\
\text { peration. }\end{array}$ & & ca's Pebble Be & \\
\hline
\end{tabular}

The INL rating of TRL-5 is based on the performance to date of experimental-scale fuel made at Babcock and Wilcox (B\&W) (UCO kernels) and Oak Ridge National Laboratory (ORNL) (TRISO-coated particles and compacts) in the AGR 1 irradiation experiment. The results show very-low fission-gas release from all six capsules in the test train. Safety testing is underway at ORNL and will start at INL in September 2011.

\subsubsection{Research and Development Tasks}

The following section is identifying the main R\&D activities being performed to meet the Fuel Qualification program goals. Those goals are to provide data for fuel performance under irradiation as 
necessary to support fuel process development, qualify fuel for normal operation conditions, and support development and validation of fuel performance and fission product transport models and codes. Provide irradiated fuel and fuel materials as necessary for PIE and safety testing.

\section{AGR-1 Shakedown Small Coater Fuel}

The AGR-1 irradiation provides experience with a multimonitored test train design, fabrication, and operation, and will reduce the chances of test train or capsule failures in subsequent test trains. Having been successfully taken to estimated design burnup and fast fluence, it will provide data on irradiated fuel performance for baseline and fuel variants selected based on data from fuel process development and existing irradiation experience.

\section{AGR-2 Production Scale Fuel Performance}

UCO compacts for this irradiation will be subjected to a range of burnups and temperatures exceeding anticipated prismatic reactor service conditions in three capsules. The test train will also include compacts containing $\mathrm{UO}_{2}$ particles in three separate capsules. The range of burnups and temperatures in these capsules will exceed anticipated PBR service conditions. This test train will provide irradiated fuel performance data and irradiated fuel samples for safety testing and PIE for key fuel product and process variants.

\section{AGR-3/4 Fission Product Transport Data}

The AGR-3/4 irradiation experiment is a combination of AGR-3 and 4, which were initially planned for separate irradiations. Designed-to-fail (DTF) fuel particles will fail early in the irradiation and provide a known source of fission products. The sweep gas will contain gaseous impurities (e.g., $\mathrm{CO}, \mathrm{H}_{2} \mathrm{O}$ ) typically found in the primary helium loop of HTGRs. This will allow an assessment of the effect of impurities on intact and DTF fuel performance and subsequent fission product transport. This experiment will also be conducted in a flux trap.

\section{AGR-5/6 Fuel Qualification (Flux Trap)}

This irradiation experiment is a combination of AGR-5 and 6, which were initially planned for separate irradiations. The test train will include a single fuel type made using process conditions and product parameters considered to provide the best prospects for successful performance based on process development results and available data from AGR-1 and 2. This will be the reference fuel design selected for qualification. Variations in capsule conditions (burnup, fast fluence, and temperature) will be established in accordance with the test specification.

\section{AGR-7/8 Fuel Performance and Fission Product Transport Verification and Validation (Flux Trap)}

AGR-7 and AGR-8 will be conducted at the same time in two separate test trains or in one test train where half is dedicated to AGR-7 and half to AGR-8. The irradiation will test fuel beyond its operating envelope so that some measurable level of fuel failure would occur (margin test). The test train will provide irradiated fuel performance data and irradiated fuel samples for safety testing and PIE to validate fission product transport codes. The sweep gas will be the same as that used in AGR-5/6.

\section{Fuel Performance Modeling}

The main purpose of this program is the development of validated fuel performance models. Fuel performance modeling addresses the structural, thermal, and chemical processes that can lead to coatedparticle failures. It considers the effect of fission product chemical interactions with the coatings, which can lead to degradation of the coated-particle properties. Fission product release from the particles and transport within the fuel compact matrix and fuel element graphite is also modeled. 


\section{Fission Product Transport and Source Term}

The goals for fission product and source term work are to satisfy the fission product transport DDNs identified for the NGNP, provide a technical basis for the source terms under normal and accident conditions, reduce the uncertainty in the source term to less than the design margins of 4 for gases and 10 for metals, and validate design methods and codes for predicting source terms for normal and accident conditions.

\subsubsection{Design Data Needs}

Several DDNs are associated with technological development of NGNP fuel elements . R\&D subtask references in the following table are taken from PLN-3636, "Fuel Development and Qualification Program" (Rev 0, 09/30/2010). The first three column references are from DDN documents (see 'References' section, numbers 15,16 and 17).

Table 12. Fuel DDNs.

\begin{tabular}{|c|c|c|c|}
\hline Number & Vendor & Description & Status \\
\hline 1.1.1.1 & AREVA & $\begin{array}{l}\text { Develop advanced carbon source } \\
\text { for UCO kernel production. Test } \\
\text { materials in pilot-facility } \\
\text { fabricating UCO kernels. }\end{array}$ & $\begin{array}{l}\text { A successful UCO kernel process improvement } \\
\text { was carried out, part of which optimized and } \\
\text { developed specifications for carbon source and } \\
\text { were used in making the fuel for AGR-2. }\end{array}$ \\
\hline 1.1 .1 .2 & AREVA & $\begin{array}{l}\text { Kernel Manufacturing. Develop } \\
\text { advanced kernel wash and dry } \\
\text { system to effectively increase } \\
\text { throughput of kernel line with no } \\
\text { degradation in kernel quality. }\end{array}$ & $\begin{array}{l}\text { Addition of a second drying station and use of } \\
\text { larger wash/dry vessels increased the throughput of } \\
\text { the B\&W fabrication process. }\end{array}$ \\
\hline $1.1 .1 .2 \mathrm{~b}$ & AREVA & $\begin{array}{l}\text { Kernel manufacturing. Enhanced } \\
\text { sintering with a focus on } \\
\text { increased throughput and } \\
\text { reduced cost. }\end{array}$ & $\begin{array}{l}\text { The kernel sintering furnace batch size was } \\
\text { increased from } 750 \mathrm{~g} \text { for AGR-1 kernels to } 1,700 \mathrm{~g} \\
\text { for AGR-2 kernels to 3,300 g for FY } 2009 \text { natural } \\
\text { uranium oxycarbide kernels. An alternative kernel } \\
\text { upgrading method will be evaluated in FY } 2011 .\end{array}$ \\
\hline 1.1.2.2 & AREVA & $\begin{array}{l}\text { Coating Manufacturing. } \\
\text { Investigate the largest coating } \\
\text { batch size that is practical in the } \\
\text { existing } 6 \text { inch coater or in a } \\
\text { larger coater. }\end{array}$ & $\begin{array}{l}\text { Multiple 6-inch-diameter coaters would be needed } \\
\text { for a production facility, and economics may } \\
\text { require ultimate demonstration and testing of fuel } \\
\text { from a coater larger than 6-inches. }\end{array}$ \\
\hline $1.1 .3 .1 \mathrm{a}$ & AREVA & $\begin{array}{l}\text { Potential sources of materials for } \\
\text { compact production, including } \\
\text { graphitic matrix and resin } \\
\text { materials, will be reviewed and } \\
\text { selections made to support } \\
\text { production of thermosetting } \\
\text { compacts. }\end{array}$ & $\begin{array}{l}\text { The present fuel fabrication program includes a } \\
\text { task to develop an improved fuel compact } \\
\text { fabrication process using a thermosetting resin- } \\
\text { based matrix. }\end{array}$ \\
\hline $1.1 .3 .1 \mathrm{~b}$ & AREVA & $\begin{array}{l}\text { Determine the irradiation } \\
\text { performance of the fuel } \\
\text { compacts to be used in the } \\
\text { NGNP conditions. }\end{array}$ & $\begin{array}{l}\text { The AGR irradiation program is determining the } \\
\text { irradiation performance of compacts anticipated to } \\
\text { be used in NGNP operational and accident } \\
\text { conditions. }\end{array}$ \\
\hline
\end{tabular}


Table 12. (continued).

\begin{tabular}{|c|c|c|c|}
\hline Number & Vendor & Description & Status \\
\hline 1.1 .3 .2 & AREVA & $\begin{array}{l}\text { Establish compact manufacturing } \\
\text { capabilities in the United States } \\
\text { based on the AREVA process. } \\
\text { Develop (or confirm) compact } \\
\text { pressures and temperatures to } \\
\text { minimize fuel damage. Develop } \\
\text { a heat treatment process to } \\
\text { ensure complete graphitization } \\
\text { of the matrix material. }\end{array}$ & $\begin{array}{l}\text { A plan in } 2009 \text { for scaled up efforts for production } \\
\text { of compacts for AGR-5/6 was developed to obtain } \\
\text { the widest possible range for packing fraction } \\
\text { adjustment without fuel damage. }\end{array}$ \\
\hline $1.1 .3 .2 \mathrm{a}$ & AREVA & $\begin{array}{l}\text { Confirm the pressures and } \\
\text { temperatures used during the } \\
\text { compact manufacturing process. }\end{array}$ & $\begin{array}{l}\text { The AGR Fuel Test Preparation program tests } \\
\text { compact properties on key process conditions; } \\
\text { temperature and pressure are two of those } \\
\text { properties. }\end{array}$ \\
\hline $1.1 .3 .2 \mathrm{~b}$ & AREVA & $\begin{array}{l}\text { Optimize the heat treatment } \\
\text { process used during compact } \\
\text { manufacture. This process must } \\
\text { ensure sufficient removal of } \\
\text { volatile materials, including } \mathrm{H}_{2} \text {, } \\
\text { from the compact matrix } \\
\text { material to produce a high } \\
\text { integrity compact. }\end{array}$ & $\begin{array}{l}\text { The AGR Fuel Test Preparation program tests } \\
\text { compact properties on key process conditions; } \\
\text { temperature and pressure are two of those } \\
\text { properties. }\end{array}$ \\
\hline 1.1.4.1 & AREVA & $\begin{array}{l}\text { Fuel Mass Production. R\&D } \\
\text { should focus on areas where } \\
\text { product uniformity and quality } \\
\text { are most at jeopardy. }\end{array}$ & $\begin{array}{l}\text { A successful UCO kernel process improvement } \\
\text { was carried out, part of which optimized and } \\
\text { developed specifications for carbon source and } \\
\text { were used in making the fuel for AGR-2. }\end{array}$ \\
\hline $1.1 .4 .1 \mathrm{a}$ & AREVA & $\begin{array}{l}\text { Fuel Mass Production. Process } \\
\text { scale-up. }\end{array}$ & $\begin{array}{l}\text { A conceptual design is needed to document the } \\
\text { basis for a full-scale fuel manufacturing plant, } \\
\text { incorporating results of development and } \\
\text { providing a solid basis for fuel costs. }\end{array}$ \\
\hline $1.1 .4 .1 \mathrm{~b}$ & AREVA & $\begin{array}{l}\text { Confirm that the irradiation } \\
\text { performance of the fuel produced } \\
\text { by the production scale processes } \\
\text { and facilities matches the } \\
\text { performance from the } \\
\text { laboratory/pilot facilities. }\end{array}$ & $\begin{array}{l}\text { A successful UCO kernel process improvement } \\
\text { was carried out, part of which optimized and } \\
\text { developed specifications for carbon source and } \\
\text { were used in making the fuel for AGR-2. }\end{array}$ \\
\hline 1.2 .1 .0 & AREVA & $\begin{array}{l}\text { Quality control (QC) methods. } \\
\text { develop highly reliable } \\
\text { instrumentation and data } \\
\text { acquisition software to ensure } \\
\text { fuel particle quality is built into } \\
\text { the fuel. }\end{array}$ & $\begin{array}{l}\text { The fuel fabrication program element includes } \\
\text { establishing the fuel fabrication infrastructure } \\
\text { using QC methods development. }\end{array}$ \\
\hline 1.2.2.0 & AREVA & $\begin{array}{l}\text { Develop QC inspection } \\
\text { techniques that directly relate to } \\
\text { irradiation performance. }\end{array}$ & $\begin{array}{l}\text { Characterization methods established at ORNL } \\
\text { were formalized in the work instructions used for } \\
\text { QC inspection and testing of fuel fabricated for } \\
\text { AGR-1 and AGR-2. These methods and } \\
\text { procedures were used to characterize the four fuel } \\
\text { variants irradiated in AGR-1. }\end{array}$ \\
\hline
\end{tabular}


Table 12. (continued).

\begin{tabular}{|c|c|c|c|}
\hline Number & Vendor & Description & Status \\
\hline 1.3.1.0 & AREVA & $\begin{array}{l}\text { Fuel Oxidation Under Water/Air } \\
\text { Ingress. Evaluate the need for } \\
\text { additional data for oxidation } \\
\text { behavior of the kernel, buffer, } \\
\text { inner pyrolytic carbon, SiC } \\
\text { (silicon carbide), outer pyrolytic } \\
\text { carbon, compact, and fuel } \\
\text { element. }\end{array}$ & $\begin{array}{l}\text { To evaluate the oxidation behavior of } \mathrm{SiC} \text {, tests are } \\
\text { planned as part of the accident heating tests in } \\
\text { AGR- } 5 \text { and } 6 \text { in which the influence of air on fuel } \\
\text { behavior is studied. }\end{array}$ \\
\hline $1.3 .1 .0 \mathrm{~b}$ & AREVA & $\begin{array}{l}\text { Fuel Compact-Fission Product } \\
\text { Interactions. Determine the } \\
\text { interactions between the fuel } \\
\text { matrix material and key } \\
\text { radionuclides that impact fission } \\
\text { product transport through the } \\
\text { matrix material. }\end{array}$ & $\begin{array}{l}\text { The Fuel Development and Qualification program } \\
\text { identifies the need to examine irradiated high } \\
\text { burnup particles that have been heated to } \\
\text { determine the magnitude of the effect of fission } \\
\text { product interactions with layers and potential } \\
\text { degradation of properties. }\end{array}$ \\
\hline 1.3.3.0 & AREVA & $\begin{array}{l}\text { Fission Product Speciation } \\
\text { During Mass Transfer. } \\
\text { Determine chemical speciation } \\
\text { of fission products within the } \\
\text { primary system and the } \\
\text { confinement for differing } \\
\text { potential atmospheres, including } \\
\text { those encountered during water } \\
\text { or air ingress events. }\end{array}$ & $\begin{array}{l}\text { Under the AGR-5/6 irradiation test program one } \\
\text { capsule in the test train will contain fuel compacts } \\
\text { with DTF particles to support post-irradiation } \\
\text { moisture ingress testing. The sweep gas will } \\
\text { contain helium, neon, and a representative set of } \\
\text { impurity gases found in the primary system } \\
\text { helium. }\end{array}$ \\
\hline $1.4 .1 .0 \mathrm{a}$ & AREVA & $\begin{array}{l}\text { Spent Fuel-Long-Term Release } \\
\text { of Fission Products from TRISO } \\
\text { Fuel. This DDN evaluates the } \\
\text { long-term fission product release } \\
\text { characteristics of the TRISO fuel } \\
\text { particles under representative } \\
\text { fuel storage conditions. }\end{array}$ & $\begin{array}{l}\text { Spent fuel storage issue. Not presently being } \\
\text { addressed by the Fuels Program. Further R\&D will } \\
\text { proceed when the NGNP design is more mature } \\
\text { and US spent fuel strategy has been established. }\end{array}$ \\
\hline С.07.01.01 & GA & $\begin{array}{l}\text { UCO Kernel Process } \\
\text { Development. }\end{array}$ & $\begin{array}{l}\text { Within the Fuel Development and Qualification } \\
\text { program one of the fuel fabrication requirements is } \\
\text { to conduct fuel kernel process studies to optimize } \\
\text { the UCO kernel fabrication process (e.g., carbon } \\
\text { dispersion, broth chemistry, calcination, } \\
\text { carburization, and sintering). }\end{array}$ \\
\hline С.07.01.02 & GA & $\begin{array}{l}\text { Fuel Particle Coating Process } \\
\text { Development. }\end{array}$ & $\begin{array}{l}\text { There is a Fuel Particle Coating Process } \\
\text { Development Plan, the initial coating process } \\
\text { development effort involved experimental work in } \\
\text { a } 2 \text { inch-diameter, laboratory-scale coater at } \\
\text { ORNL. }\end{array}$ \\
\hline С.07.01.03 & GA & $\begin{array}{l}\text { Fuel Compact Fabrication } \\
\text { Process. }\end{array}$ & $\begin{array}{l}\text { There is a Fuel Compacting Process Development } \\
\text { Plan. The initial compacts were developed and } \\
\text { modeled at ORNL and produced compacts for the } \\
\text { use in AGR-1 and AGR- } 2 \text { irradiations. }\end{array}$ \\
\hline С.07.01.04 & GA & $\begin{array}{l}\text { QC Test Techniques } \\
\text { Development. }\end{array}$ & $\begin{array}{l}\text { B\&W has implemented QC processes and } \\
\text { analytical procedures to ensure that the kernels and } \\
\text { coated particles they produce will comply with } \\
\text { AGR specifications. }\end{array}$ \\
\hline С.07.01.05 & GA & $\begin{array}{l}\text { Fuel Product Recovery } \\
\text { Development. }\end{array}$ & $\begin{array}{l}\text { Spent fuel storage issue; not presently being } \\
\text { addressed by the Fuels Program. }\end{array}$ \\
\hline
\end{tabular}


Table 12. (continued).

\begin{tabular}{|c|c|c|c|}
\hline Number & Vendor & Description & Status \\
\hline C.07.02.01 & GA & Coating Material Property Data. & $\begin{array}{l}\text { Part of the Fuel Fabrication program is to produce } \\
\text { a full set of coating material property data based } \\
\text { on a number of differing coating parameters. }\end{array}$ \\
\hline C.07.02.02 & GA & $\begin{array}{l}\text { Defective Particle Performance } \\
\text { Data. }\end{array}$ & $\begin{array}{l}\text { Part of the Fuels and Materials Irradiations, Safety } \\
\text { Testing and PIE is to have representative fuel } \\
\text { containing DTF particles in support of fission } \\
\text { product transport model development (AGR-3/4). }\end{array}$ \\
\hline C.07.02.03 & GA & $\begin{array}{l}\text { Thermochemical Performance } \\
\text { Data for Fuel. }\end{array}$ & $\begin{array}{l}\text { In the Fuel Performance Modeling program there } \\
\text { are thermochemical test plans for fuel for normal } \\
\text { operation and under accident conditions. }\end{array}$ \\
\hline C.07.02.04 & GA & $\begin{array}{l}\text { Fuel Compact Thermophysical } \\
\text { Properties. }\end{array}$ & $\begin{array}{l}\text { In the Fuel Performance Modeling program there } \\
\text { are thermophysical test plans for fuel compacts. }\end{array}$ \\
\hline C.07.02.05 & GA & $\begin{array}{l}\text { Normal Operation Fuel } \\
\text { Performance Validation Data. }\end{array}$ & $\begin{array}{l}\text { In the Fuel Performance Modeling program there } \\
\text { are normal operational fuel performance tests. }\end{array}$ \\
\hline C.07.02.06 & GA & $\begin{array}{l}\text { Accident Fuel Performance } \\
\text { Validation Data. }\end{array}$ & $\begin{array}{l}\text { In the Fuel Performance Modeling program there } \\
\text { are accident operational fuel performance tests. }\end{array}$ \\
\hline C.07.02.07 & GA & Fuel Proof Test Data. & $\begin{array}{l}\text { There is a requirement in the fuel qualification } \\
\text { program to conduct fuel coating process studies to } \\
\text { determine the adaptability of the German-like } \\
\text { coating process to NGNP fuel and to establish } \\
\text { coating conditions that yield coating layers having } \\
\text { microstructural properties and features comparable } \\
\text { to the coating layers on the German fuel particles } \\
\text { in proof-test composite EUO 2358-2365. }\end{array}$ \\
\hline C.07.03.01 & GA & $\begin{array}{l}\text { Fission Gas Release from Core } \\
\text { Materials. }\end{array}$ & $\begin{array}{l}\text { AGR-3/4 will provide irradiated fuel performance } \\
\text { data on fission product gas release from failed } \\
\text { particles and irradiated fuel. The inpile gas release, } \\
\text { PIE, and safety testing data on fission gas and } \\
\text { metal release from kernels will be used in the } \\
\text { development of improved fission product transport } \\
\text { models. }\end{array}$ \\
\hline C.07.03.02 & GA & $\begin{array}{l}\text { Fission Metal Effective } \\
\text { Diffusivities in Fuel Kernels. }\end{array}$ & $\begin{array}{l}\text { Part of the Fission Product Transport and Source } \\
\text { Term activity there is a Task } 3.5 .2 \text { to investigate } \\
\text { fission metal effective diffusivities in fuel kernels. }\end{array}$ \\
\hline C. 07.03 .03 & GA & $\begin{array}{l}\text { Fission Product Effective } \\
\text { Diffusivities in Particle Coating. }\end{array}$ & $\begin{array}{l}\text { Part of the Fission Product Transport and Source } \\
\text { Term activity there is a Task } 3.5 .3 \text { to investigate } \\
\text { fission product effective diffusivities in particle } \\
\text { coatings. }\end{array}$ \\
\hline C.07.03.04 & GA & $\begin{array}{l}\text { Fission Product } \\
\text { Diffusivities/Sorptivities in } \\
\text { Graphite. }\end{array}$ & $\begin{array}{l}\text { For AGR-3/4 irradiation the test train is designed } \\
\text { to provide data on fission product diffusivities in } \\
\text { fuel kernels and sorptivities and diffusivities in } \\
\text { compact matrix and graphite materials for use in } \\
\text { upgrading fission product transport models. }\end{array}$ \\
\hline N.07.01.07 & GA & $\begin{array}{l}\text { As-manufactured Quality of Low } \\
\text { Enriched Uranium UO2 } \\
\text { (extended burnup fuel). }\end{array}$ & $\begin{array}{l}\text { The Fuel Fabrication program element includes } \\
\text { establishing the fuel fabrication infrastructure } \\
\text { using QC methods development. }\end{array}$ \\
\hline N.07.02.08 & GA & $\begin{array}{l}\text { Irradiation Performance of Low } \\
\text { Enriched Uranium UO2 } \\
\text { (extended burnup fuel). }\end{array}$ & $\begin{array}{l}\text { The AGR irradiation program is determining the } \\
\text { irradiation performance of compacts anticipated to } \\
\text { be used in NGNP operational and accident } \\
\text { conditions. }\end{array}$ \\
\hline
\end{tabular}


Table 12. (continued).

\begin{tabular}{|c|c|c|c|}
\hline Number & Vendor & Description & Status \\
\hline N.07.02.09 & GA & $\begin{array}{l}\text { Accident Performance of Low } \\
\text { Enriched Uranium UO2 } \\
\text { (extended burnup fuel). }\end{array}$ & $\begin{array}{l}\text { In the fuel performance modeling program there } \\
\text { are accident operational fuel performance tests. }\end{array}$ \\
\hline N.07.03.19 & GA & $\begin{array}{l}\text { Physical and Chemical Forms of } \\
\text { Radionuclides Released During } \\
\text { Core Heat-up. }\end{array}$ & $\begin{array}{l}\text { The Fuel Development And Qualification program } \\
\text { identifies the need to examine irradiated high } \\
\text { burnup particles that have been heated to } \\
\text { determine the magnitude of the effect of fission } \\
\text { product interactions with layers and potential } \\
\text { degradation of properties. }\end{array}$ \\
\hline N.07.03.20 & GA & $\begin{array}{l}\text { Data are needed to characterize } \\
\text { the deposition of I, Cs, Ag and } \\
\text { Te on prominent Vented Low- } \\
\text { Pressure Building (VLPB) } \\
\text { surfaces (paint, concrete, etc.), } \\
\text { including the sorptivities of these } \\
\text { nuclides as a function of } \\
\text { temperature, partial pressure, } \\
\text { surface state, and coolant } \\
\text { chemistry. }\end{array}$ & $\begin{array}{l}\text { R\&D Subtask 3.5.11.1: New DDNs need to be } \\
\text { defined for characterizing radionuclide transport in } \\
\text { the VLPB for the accident scenarios postulated for } \\
\text { the NGNP. A plan needs to be developed, defining } \\
\text { an experimental/analytical program to satisfy the } \\
\text { DDNs, and be executed. The radionuclides of } \\
\text { interest are I, Cs, Sr, Te, and Ag. }\end{array}$ \\
\hline N.07.03.21 & GA & $\begin{array}{l}\text { Qualification of Coatings with } \\
\text { High Iodine Sorptivity. }\end{array}$ & $\begin{array}{l}\text { A test plan to characterize radionuclide transport in } \\
\text { a VLPB has been published "Test Plan to } \\
\text { Characterize Radionuclide Transport in a Vented } \\
\text { Low-Pressure Containment," General Atomics, } \\
\text { PC- } 000573 \text {, Rev. 0, September 2008. Part of the } \\
\text { plan includes the investigation of coatings with } \\
\text { high iodine sorptivities. }\end{array}$ \\
\hline N.07.03.22 & GA & $\begin{array}{l}\text { Validation Data for Predicting } \\
\text { Radionuclide Transport in } \\
\text { VLPB. Integral test data are } \\
\text { needed to independently validate } \\
\text { the methods describing the } \\
\text { transport behavior of } \\
\text { condensable radionuclides in the } \\
\text { VLPB under dry and wet core } \\
\text { conduction cooldown conditions. }\end{array}$ & $\begin{array}{l}\text { A test plan to characterize radionuclide transport in } \\
\text { a VLPB has been published "Test Plan to } \\
\text { Characterize Radionuclide Transport in a Vented } \\
\text { Low-Pressure Containment," General Atomics, } \\
\text { PC-000573, Rev. 0, September } 2008 \text {. }\end{array}$ \\
\hline N.07.03.23 & GA & $\begin{array}{l}\text { Data are needed to determine } \mathrm{H}- \\
3 \text { release rates from failed and } \\
\text { intact, fuel particles, reference } \\
\text { TRISO particles as a function of } \\
\text { temperature and burnup. }\end{array}$ & $\begin{array}{l}\text { A test plan for characterizing tritium transport has } \\
\text { been published as, "Test Plan for Characterizing } \\
\text { Tritium Transport in a VHTR," General Atomics, } \\
\text { PC-000550, Rev. 0, December 2007. In R\&D Task } \\
\text { 3.5.13, tritium transport sets out to provide the } \\
\text { experimental bases for improving component } \\
\text { models and material property correlations to } \\
\text { describe H-3 transport behavior in HTGRs. }\end{array}$ \\
\hline N.07.03.24 & GA & $\begin{array}{l}\text { Tritium Release from Control } \\
\text { Materials. Data are needed to } \\
\text { determine } \mathrm{H}_{3} \text { retention by boron- } \\
\text { based control materials. }\end{array}$ & $\begin{array}{l}\text { R\&D Subtask } 3.5 .13 .3 \text { is to measure fractional } \\
\text { releases of tritium from boron carbide }(\mathrm{B} 4 \mathrm{C}) \\
\text { granules as a function of temperature, time, fast } \\
\text { fluence, irradiation temperature, and water partial } \\
\text { pressure. }\end{array}$ \\
\hline
\end{tabular}


Table 12. (continued).

\begin{tabular}{|c|c|c|c|}
\hline Number & Vendor & Description & Status \\
\hline N.07.05.01 & GA & $\begin{array}{l}\text { Long-Term Mechanical Integrity } \\
\text { of Stressed TRISO Coatings. }\end{array}$ & $\begin{array}{l}\text { Spent fuel storage issue is not presently being } \\
\text { addressed by the Fuels program. Further R\&D will } \\
\text { proceed when the NGNP design is more mature } \\
\text { and the U.S. spent fuel strategy has been } \\
\text { established. }\end{array}$ \\
\hline N.07.05.02 & GA & $\begin{array}{l}\text { PyC Coating Oxidation Rates } \\
\text { (Air). }\end{array}$ & $\begin{array}{l}\text { R\&D Subtask } 3.5 .13 .4 \text { investigates the oxidation } \\
\text { resistance to B4C granules when applying PyC } \\
\text { coating to the granules. }\end{array}$ \\
\hline N.07.05.03 & GA & $\begin{array}{l}\text { SiC Coating Oxidation Rates } \\
\text { (Air). }\end{array}$ & $\begin{array}{l}\text { Tests are planned to evaluate the oxidation } \\
\text { behavior of SiC as part of the accident heating } \\
\text { tests in AGR- } 5 \text { and } 6 \text { in which the influence of air } \\
\text { on fuel behavior is studied. }\end{array}$ \\
\hline N.07.05.07 & GA & $\begin{array}{l}\text { PyC Coating Corrosion Rates } \\
\text { (Groundwater). }\end{array}$ & $\begin{array}{l}\text { Spent fuel storage issue is not presently being } \\
\text { addressed by the Fuels program. Further R\&D will } \\
\text { proceed when the NGNP design is more mature } \\
\text { and U.S. spent fuel strategy has been established. }\end{array}$ \\
\hline N.07.05.08 & GA & $\begin{array}{l}\text { SiC Coating Corrosion Rates } \\
\text { (Groundwater). }\end{array}$ & $\begin{array}{l}\text { Spent fuel storage issue is not presently being } \\
\text { addressed by the Fuels program. Further R\&D will } \\
\text { proceed when the NGNP design is more mature } \\
\text { and U.S. spent fuel strategy has been established. }\end{array}$ \\
\hline N.07.05.09 & GA & $\begin{array}{l}\text { Matrix Corrosion Rates } \\
\text { (Groundwater). }\end{array}$ & $\begin{array}{l}\text { Spent fuel storage issue is not presently being } \\
\text { addressed by the Fuels Program. Further R\&D will } \\
\text { proceed when the NGNP design is more mature } \\
\text { and US spent fuel strategy has been established. }\end{array}$ \\
\hline N.07.05.10 & GA & $\begin{array}{l}\text { Graphite Corrosion Rates } \\
\text { (Groundwater). }\end{array}$ & $\begin{array}{l}\text { Spent fuel storage issue is not presently being } \\
\text { addressed by the Fuels program. Further R\&D will } \\
\text { proceed when the NGNP design is more mature } \\
\text { and U.S. spent fuel strategy has been established. }\end{array}$ \\
\hline N.07.05.11 & GA & $\begin{array}{l}\text { Radionuclide Leaching Rates } \\
\text { From UCO Kernels. }\end{array}$ & $\begin{array}{l}\text { The ORNL laboratory provides the capability for } \\
\text { inspection and testing of UCO kernels. It performs } \\
\text { leach-burn-leach testing of fuel compacts to } \\
\text { determine the defective } \mathrm{SiC} \text { and uranium } \\
\text { contamination fractions and the quantity of } \\
\text { specified impurities outside the } \mathrm{SiC} \text { layer. }\end{array}$ \\
\hline NHSS-01-01 & WEC & $\begin{array}{l}\text { Fuel irradiation tests for normal } \\
\text { operational conditions. }\end{array}$ & $\begin{array}{l}\text { Covered by the AGR-1 through AGR } 8 \text { irradiation } \\
\text { program. }\end{array}$ \\
\hline NHSS-01-02 & WEC & $\begin{array}{l}\text { Fuel heating tests for accident } \\
\text { conditions. }\end{array}$ & $\begin{array}{l}\text { Covered by the AGR-1 through AGR } 8 \text { irradiation } \\
\text { program. }\end{array}$ \\
\hline NHSS-01-03 & WEC & Fuel graphite irradiation tests. & $\begin{array}{l}\text { Covered by the AGC- } 1 \text { through AGC } 6 \text { irradiation } \\
\text { program. }\end{array}$ \\
\hline
\end{tabular}

\subsubsection{Additional Technological Development}

A number of follow-on activities are required to support future efforts to achieve a cost-competitive HTGR fuel manufacturing capability. This section identifies some proposed programs, but there is no specific test plan identified for this work, nor a schedule identified for these activities. These are effectively follow-on activities to be performed at a later date. 


\section{Process Improvement Studies and Evaluations}

Studies or evaluations may be defined based on uncertainties in the assumptions used in the initial fuel cost estimate or recommendations from the conceptual design (see below). These studies could, for example, evaluate larger diameter kernel fabrication equipment, evaluate ways to reduce waste and improve yields, operate the forming column in a continuous mode, and eliminate manual transfers.

\section{Waste Treatment Evaluation and Waste Minimization Plan}

The process flow diagrams and material balances developed for the initial fuel cost estimate will serve as the starting point for waste treatment evaluations and developing a waste minimization plan. Waste and scrap from AGR-1 and AGR-2 fuel fabrication processes have been stored or disposed of in ways that will not be possible for waste from full-scale fabrication facilities. Process changes may be required to avoid mixed (hazardous and radioactive) waste. The waste minimization plan will consider all scrap and waste streams generated by the fabrication processes and recommend ways to avoid and reduce wastes by process changes, identify streams that can be recycled, discuss unit operations required for recycle, and define waste treatment processes required prior to offsite disposal.

\section{Fuel Characterization Plan and Automated QC Method Evaluations}

Characterization of AGR-1 and AGR-2 fuel to determine compliance with specifications required much more calendar time than fabricating the fuels, and it consumed a large fraction of the fuel produced. Ideally, QC methods that are nondestructive, allow for near real-time feedback, and allow for large throughputs or $100 \%$ inspection is desired for a fabrication facility. The plan will provide an initial evaluation of whether new techniques are needed, whether automation of current techniques is possible, and if so, what development is recommended.

\section{Fuel Manufacturing Plant Conceptual Design}

A conceptual design is needed to document the basis for a full-scale fuel manufacturing plant, incorporating results of development and providing a solid basis for fuel costs. The conceptual design along with studies and data, which support the design, provide the source documents to develop risk management plans, safety and hazards analyses, and cost estimates. The basis for the conceptual design starts with input from the NGNP design. A Technical and Functional Requirements document is developed and expanded in a Conceptual Design Criteria document that provides the basis for the conceptual design.

\subsubsection{Risk Analysis and PIRTs}

The NGNP risks database (NGNP_RMS_V2_D_15SEP2010.mdb) identifies a number of risks and PIRTs associated with the fuel elements. Table 13 is a table identifying how those risks are mitigated by the Fuel R\&D test plans.

Table 13. Risk and PIRT analysis.

\begin{tabular}{|c|c|c|c|}
\hline Risk Title & Description & Associated PIRTs & Status \\
\hline $\begin{array}{l}\text { 393. Burnup } \\
\text { Safety. }\end{array}$ & $\begin{array}{l}\text { The safety case may not } \\
\text { be demonstrated at } \\
\text { burnups beyond } \sim 10 \% \\
\text { fissions per initial metal } \\
\text { atom in either } \mathrm{UO}_{2} \text { or } \\
\text { UCO TRISO-coated } \\
\text { fuel. }\end{array}$ & $\begin{array}{l}\text { 6844-329. Kernel: Buffer } \\
\text { interaction. } \\
\text { 6844-127. Kernel: Grain growth. } \\
\text { 6844-328. Kernel: Kernel swelling. } \\
\text { 6844-A6. Kernel: Microstructure } \\
\text { changes. }\end{array}$ & $\begin{array}{l}\text { Kernel buffer interaction, } \\
\text { growth, swelling, and micro- } \\
\text { structural changes will be } \\
\text { characterized during PIE of } \\
\text { AGR fuel and fission product } \\
\text { release tests. }\end{array}$ \\
\hline
\end{tabular}


Table 13. (continued).

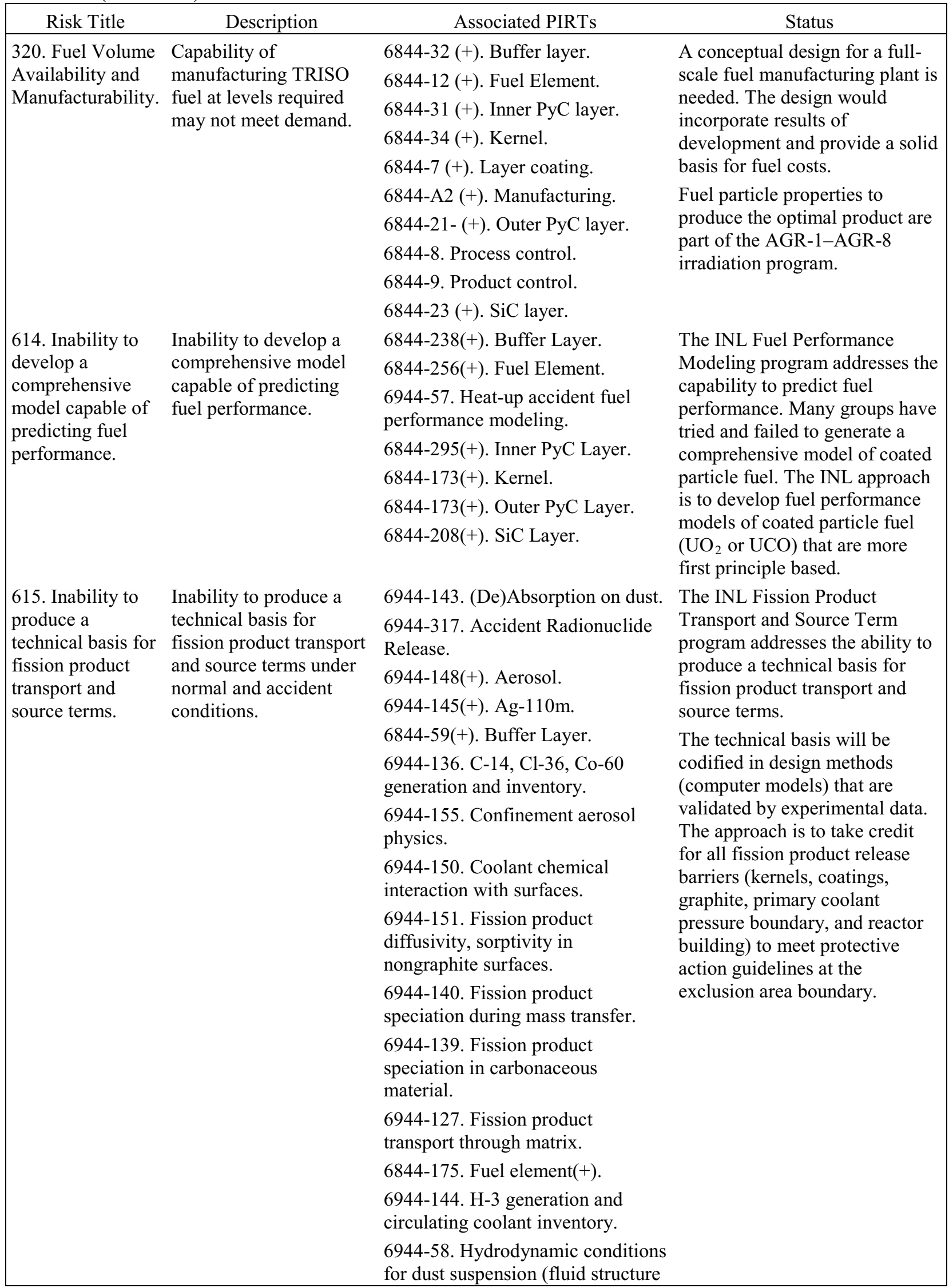


Table 13. (continued).

\begin{tabular}{|c|c|c|c|}
\hline Risk Title & Description & Associated PIRTs & Status \\
\hline & & interactions). & \\
\hline & & 6844-104(+). Inner PyC Layer. & \\
\hline & & 6844-45(+) Kernel. & \\
\hline & & $\begin{array}{l}\text { 6944-126. Matrix permeability, } \\
\text { tortuosity. }\end{array}$ & \\
\hline & & 6944-147. Nucleation. & \\
\hline & & $\begin{array}{l}\text { 6944-146. Other activation } \\
\text { products (e.g., Cs-134, Mn-55, Fe- } \\
56) \text {. }\end{array}$ & \\
\hline & & $\begin{array}{l}6844-87(+) . \text { Outer PyC Layer Gas- } \\
\text { phase diffusion. }\end{array}$ & \\
\hline & & $\begin{array}{l}\text { 6944-251. Oxidation of irradiated } \\
\text { graphite, including potential } \\
\text { adsorbed/absorbed Fission product. }\end{array}$ & \\
\hline & & 6944-154. Resuspension. & \\
\hline & & 6844-275(+). SiC Layer. & \\
\hline & & 6944-134. Sorptivity graphite. & \\
\hline & & 6944-149. Surface roughness. & \\
\hline & & 6944-159. Wash-off. & \\
\hline \multirow[t]{3}{*}{$\begin{array}{l}\text { 341. Reactor Fuel } \\
\text { Qualification. }\end{array}$} & $\begin{array}{l}\text { The lack of a fuel design } \\
\text { may impact the }\end{array}$ & $\begin{array}{l}6944-54 \text {. Core effective thermal } \\
\text { conductivity. }\end{array}$ & \multirow{3}{*}{$\begin{array}{l}\text { The objective of the DOE AGR } \\
\text { Fuel Development and } \\
\text { Qualification program is to } \\
\text { qualify TRISO-coated particle } \\
\text { fuel for use in HTGRs. }\end{array}$} \\
\hline & $\begin{array}{l}\text { qualification schedule } \\
\text { for NGNP. The reactor } \\
\text { fuel (TRISO) and } \\
\text { graphite are not qualified } \\
\text { and may require }\end{array}$ & $\begin{array}{l}\text { 6944-28. Core specific heat } \\
\text { function. } \\
6944-26 . \text { Core thermal } \\
\text { conductivity (effective). }\end{array}$ & \\
\hline & $\begin{array}{l}\text { excessive expenditures } \\
\text { (cost and schedule). }\end{array}$ & $\begin{array}{l}\text { 6944-16. Effective fuel element } \\
\text { thermal conductivity. }\end{array}$ & \\
\hline
\end{tabular}

\subsubsection{Technology Development Roadmap}

A TDRM for NGNP R\&D Fuel Element is shown in Appendix A.

\subsubsection{Section Summary}

There are two areas in the fuels program where a DDN and/or risk are not currently being addressed. The first area is related to the fuel mass production process where the program has identified that a conceptual design is needed to document the basis for a full-scale fuel manufacturing plant, incorporating results of development and providing a solid basis for fuel costs.

The second area is related to spent fuel storage and long term release of fission products. Further R\&D will proceed when the NGNP design is more mature and US spent fuel strategy has been established. 


\subsection{Graphite}

The principle Graphite R\&D activity is the qualification of graphite for use in the NGNP reactor core and core structures.

\subsubsection{Graphite Design Description}

Reactor core and core structure refer to the reactor core and its support structure. The reactor core provides the housing for the fissile fuel material, moderator material, control rods, and reflectors. The fuel material is the source of heat while undergoing the fission reaction. The moderator material, which may be fixed in place or placed in the moveable control rods, moderates or controls the sustained fission reaction. The reflectors provide containment and assist in sustaining the reaction. Figure 4 depicts a representative annular prismatic reactor core design showing these components. The core structure also provides channels for the flow of helium coolant for heat exchange.
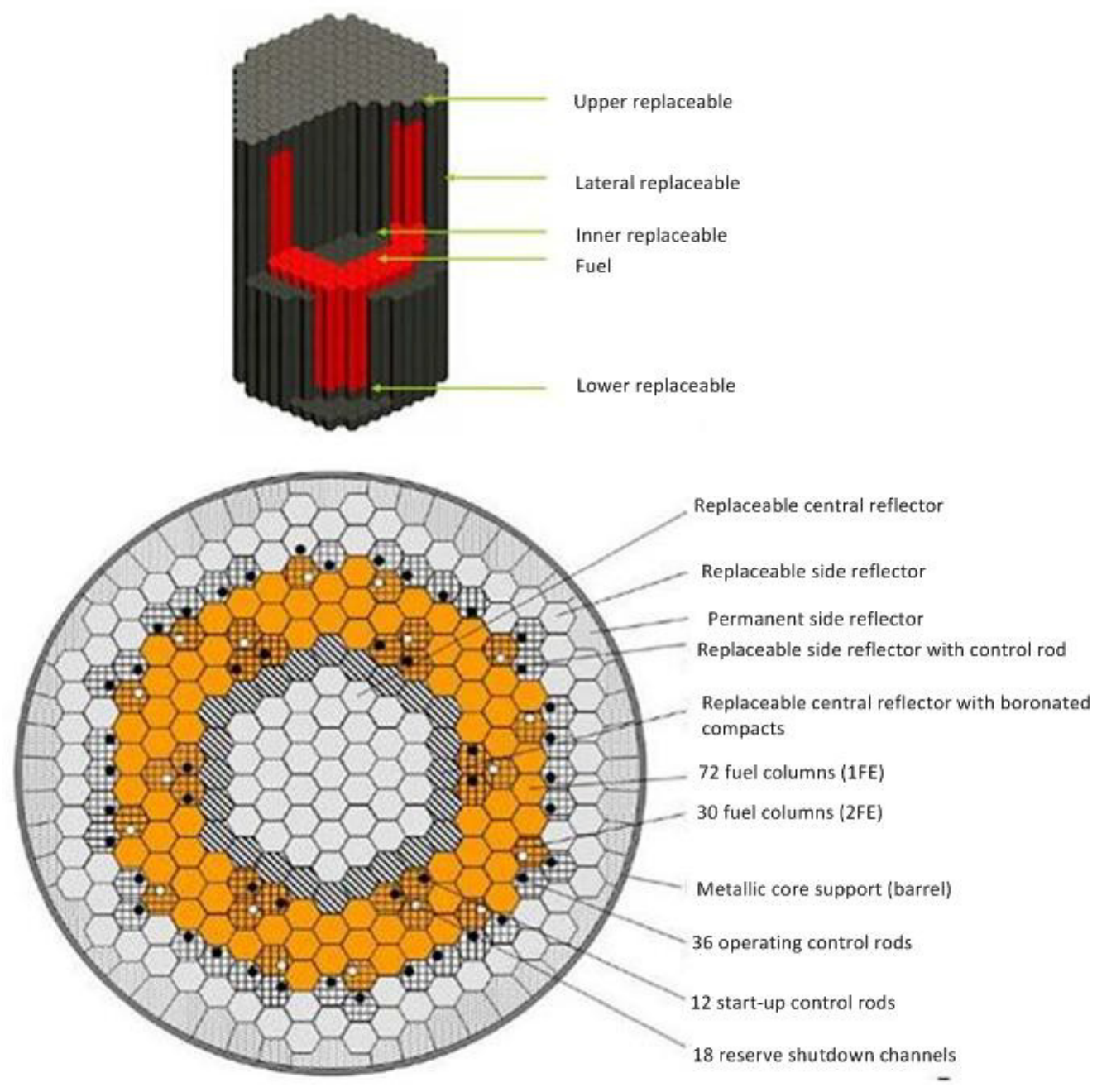

Figure 4. Representative annular prismatic core design. 


\section{Functions Performed}

The functions performed by the Reactor Core are as follows:

1. Start the reaction.

2. Generate high-temperature heat using nuclear fission.

3. Transfer the heat to the helium coolant.

4. Control radiation from the core.

5. Sustain the fission reaction through neutron reflection in the core.

6. Maintain flow passage configuration.

7. Limit the temperatures and the fast neutron fluence.

\subsubsection{Research and Development Test Plans}

The $R \& D$ test plans are focused on the R\&D activities and associated rationale necessary to qualify nuclear grade graphite for use within the NGNP reactor.

\subsubsection{Reactor Core and Core Structure status}

The General Atomics conceptual design report for the SC-MHR demonstration plant (NGNPR00016; Rev 0) identifies graphite at TRL-6. The reactor vendors AREVA and Westinghouse are in line with the INL TRL-4.

While the general characteristics necessary for producing nuclear grade graphite are understood, historical nuclear grades no longer exist. New grades must therefore be fabricated, characterized, and irradiated to demonstrate that current grades of graphite exhibit acceptable nonirradiated and irradiated properties upon which the thermomechanical design of the structural graphite in NGNP is based. For that reason INL considers a TRL-4 to more accurately reflect the current state of nuclear graphite technology.

Table 14. TRL determination by each reactor supplier and INL.

\begin{tabular}{|ccccc|}
\hline System & AREVA & GA & Westinghouse & INL \\
\hline Reactor Core and Core Structures & 4 & 6 & 4 & 4 \\
\hline
\end{tabular}

\subsubsection{Research and Development Tasks}

The scientific and engineering techniques described in this section encompass all the anticipated tests required to validate and qualify nuclear grade graphite for use with the NGNP. The tests represent the information needed for a full operational license of the prismatic NGNP reactor design.

\section{Non-irradiated Material Testing}

The graphite material properties are expected to vary throughout the billets or blocks of graphite, mapping of the magnitude and spatial positions of variability is important in determining an individual component's material properties. Physical, thermal, and mechanical property testing of multiple graphite samples from a large billet sample matrix is therefore necessary to determine the proper statistical ranges of values. 


\section{Irradiation Experiments}

The core graphite will be exposed to a high energy neutron environment; a series of irradiation experiments are required to determine the graphite response under irradiation.

The Advanced Graphite Creep (AGC) experiment is designed to provide irradiation creep rates for moderate doses and higher temperatures of leading graphite types that will be used in the NGNP reactor design. The AGC program consists of six experiments (AGC-1 to AGC-6) that will provide data for the graphite material property database, which identifies irradiation, thermal, mechanical, and physical properties. All specimens are maintained at a constant temperature during exposure times of between 6 and 20 months, depending on the required dose. PIE characterization is projected to take approximately 14 to 18 months for each capsule.

\section{High Dose Irradiation Experiments}

The high-dose experiment is designed to provide irradiation exposure for very high doses and moderate temperatures. The PBR design expects the facing reflector blocks (inner and outer reflector) to operate for much longer times, thus withstanding a maximum of irradiation damage before the core is shutdown, defueled, and the blocks replaced ( $\sim 20$ to 25 years). Since these dose levels are expected after 25 years of service, the high dose experiments are not needed for initial material property ranges specifically required for reactor licensing and startup operations. Results from this experiment will most likely be delayed until after reactor startup.

\section{Material Characterization}

These material tests will be applied to both irradiated and as received graphite samples to ascertain the changes to the material properties resulting from a neutron radiation field. The tests will cover physical, thermal, and mechanical properties.

- Physical testing will consist of microstructural characterization, irradiation dimensional change, isotropy of microstructure, chemical impurities, and elastic and shear modulus. Inspecting billets without damage to ensure proper microstructural development is one of the largest problems facing any QA program purchasing nuclear grade graphite.

- Thermal testing will be on button samples to determine thermal expansion and conductivity, rate of oxidation, emissivity values, and specific heat determination.

- Mechanical testing is the most extensive and complex part of the graphite test program. An extensive irradiation creep program is planned to characterize graphite creep response as part of a larger irradiated materials characterization program. Standard strength testing techniques using stress-strain curve relationships will provide the bulk of the mechanical material properties.

- Tribology (wear/friction) testing procedures will be used to determine wear, friction, and dust generation values for selected grades of graphite. Previously irradiated and oxidized graphite will be subjected to similar tests to determine any changes. These will be limited studies focused on those graphite types of interest to pebble bed designs.

\section{Multiscale Model Development}

Models are required to allow the designer to assess the condition of graphite components and core structure design margins at any point in the lifetime of the reactor. The primary objective of these models is to provide the ability to calculate in-service stresses and strains in graphite components and estimate the structural integrity of the core as a whole.

- Whole graphite core and component behavior models are required to define the core condition at all times during core life. Core and component-scale models will allow designers to predict core and core 
block (e.g., reflector or fuel element) dimensional distortion, component stresses, residual strength, and probability of failure during normal or off-normal conditions.

- Macroscale material behavior models are needed to predict the effects of temperature, neutron dose, and oxidation weight-loss on key physical mechanical properties.

- Microscale/nanoscale models provide a fundamental understanding of material behavior. The development of nanoscale and microscale models will underpin the macroscale materials property models, as well as provide valuable input for experimental validation requirements.

\subsubsection{Design Data Needs}

The DDNs for the reactor core and core structures are focused around the technological development of graphite. There are several DDNs associated with the technological development of the NGNP reactor core graphite. The references identified in the 'status' column in Table 15 are taken from PLN-2497, "Graphite Technology Development Plan" (Rev. 1, October 4, 2010). The first three column references are from DDN documents (see 'References' section, numbers 15, 16 and 17).

Table 15. Reactor core and core structures DDNs.

\begin{tabular}{|c|c|c|c|}
\hline Number & Vendor & Description & Status \\
\hline 2.4.1.0 & AREVA & $\begin{array}{l}\text { Graphite: Study Thermal-Physical } \\
\text { Properties (K, coefficient of } \\
\text { thermal expansion, Cp, } \\
\text { emissivity). }\end{array}$ & $\begin{array}{l}\text { Covered under Section 5.1.4 Materials } \\
\text { Characterization. Thermal, physical and } \\
\text { mechanical properties are tested. }\end{array}$ \\
\hline 2.4.1.0a & AREVA & $\begin{array}{l}\text { Graphite: Thermal-Physical } \\
\text { Properties. }\end{array}$ & $\begin{array}{l}\text { Covered under Section 5.1.4 Materials } \\
\text { Characterization. Thermal, physical and } \\
\text { mechanical properties are tested. }\end{array}$ \\
\hline $2.4 .1 .0 \mathrm{~b}$ & AREVA & Graphite: Mechanical Properties. & $\begin{array}{l}\text { Covered under Section 5.1.4 Materials } \\
\text { Characterization. Thermal, physical and } \\
\text { mechanical properties are tested. }\end{array}$ \\
\hline $2.4 .1 .0 \mathrm{c}$ & AREVA & $\begin{array}{l}\text { Graphite: Physical } \\
\text { Characteristics. }\end{array}$ & $\begin{array}{l}\text { Covered under Section 5.1.4 Materials } \\
\text { Characterization. Thermal, physical and } \\
\text { mechanical properties are tested. }\end{array}$ \\
\hline 2.4.1.0d & AREVA & Graphite: Fracture Properties. & $\begin{array}{l}\text { Covered under Section 5.1.4 Materials } \\
\text { Characterization. Thermal, physical and } \\
\text { mechanical properties are tested. }\end{array}$ \\
\hline 2.4.1.0f & AREVA & $\begin{array}{l}\text { Graphite: Air Oxidation } \\
\text { Characteristics and Effect on } \\
\text { Material Properties. }\end{array}$ & $\begin{array}{l}\text { Oxidation studies covering development of } \\
\text { ASTM test standards for oxidation testing } \\
\text { of nuclear graphite as well as determining } \\
\text { oxidation rates of nonirradiated and } \\
\text { irradiated graphite. Sections 5.1.4 and } \\
\text { 5.1.4.2, Oxidation. }\end{array}$ \\
\hline 2.4.1.0g & AREVA & $\begin{array}{l}\text { Graphite: Water/Steam Oxidation } \\
\text { Characteristics and Effect on } \\
\text { Material Properties. }\end{array}$ & $\begin{array}{l}\text { Section } 5.1 .4 \text {, Table } 4 \text { addresses the } \\
\text { oxidation behavior in the presence of } \\
\text { impurities }\left(\mathrm{O}_{2}, \mathrm{CO}_{2}, \mathrm{H}_{2} \mathrm{O}\right) \text { for acute } \\
\text { accident and chronic normal operations. }\end{array}$ \\
\hline 2.4.1.0h & AREVA & $\begin{array}{l}\text { Graphite: Impure Helium } \\
\text { Oxidation Characteristics and } \\
\text { Effect on Material Properties. }\end{array}$ & $\begin{array}{l}\text { Section } 5.1 .4 \text {, Table } 4 \text { addresses the } \\
\text { oxidation behavior in the presence of } \\
\text { impurities }\left(\mathrm{O}_{2}, \mathrm{CO} 2, \mathrm{H}_{2} \mathrm{O}\right) \text { for acute } \\
\text { accident and chronic normal operations. }\end{array}$ \\
\hline
\end{tabular}


Table 15. (continued).

\begin{tabular}{|c|c|c|c|}
\hline Number & Vendor & Description & Status \\
\hline 2.4.3.0 & AREVA & $\begin{array}{l}\text { Graphite Machine Ability. } \\
\text { Review the various fabrication } \\
\text { techniques necessary to produce a } \\
\text { finished graphite fuel or reflector } \\
\text { block from a graphite billet. }\end{array}$ & $\begin{array}{l}\text { Fabrication techniques are not part of the } \\
\text { scope of the R\&D activities identified in } \\
\text { the Graphite Technology Development } \\
\text { Plan. }\end{array}$ \\
\hline 4.1.2.2 & AREVA & $\begin{array}{l}\text { Thermal-Hydraulics: STAR-CD } \\
\text { Graphite Oxidation Model } \\
\text { Development for Water and Air } \\
\text { Ingress. }\end{array}$ & $\begin{array}{l}\text { Sections } 5.2 .1 \text { Whole graphite core and } \\
\text { component behavior models and } 5.2 .2 \\
\text { macroscale materials behavior models } \\
\text { address the modeling oxidation properties } \\
\text { and weight loss. }\end{array}$ \\
\hline 4.1.4.2a & AREVA & $\begin{array}{l}\text { Structural Analysis: Completion } \\
\text { of Experimental Databases for } \\
\text { Structural Mechanics Codes. }\end{array}$ & $\begin{array}{l}\text { The structural mechanical code database } \\
\text { will be populated by the material } \\
\text { characterization program the properties of } \\
\text { which are identified in Section } 5.1 .4 \text {, Table } \\
4 \text {. }\end{array}$ \\
\hline 4.1.4.2b & AREVA & $\begin{array}{l}\text { Structural Analysis: Development } \\
\text { of Block-Type Core Dynamic } \\
\text { Modeling. }\end{array}$ & $\begin{array}{l}\text { Core block modeling is addressed in } \\
\text { Section 5.2.1, Whole graphite core and } \\
\text { component behavior models. }\end{array}$ \\
\hline 4.1.4.3 & AREVA & $\begin{array}{l}\text { Chemistry Effects of } \\
\text { Steam/Water. }\end{array}$ & $\begin{array}{l}\text { Section } 5.1 .4 \text {, Table } 4 \text { addresses the } \\
\text { oxidation behavior in the presence of } \\
\text { impurities }\left(\mathrm{O}_{2}, \mathrm{CO}_{2}, \mathrm{H}_{2} \mathrm{O}\right) \text { for acute } \\
\text { accident and chronic normal operations. }\end{array}$ \\
\hline C. 11.03 .11 & GA & $\begin{array}{l}\text { Graphite Multiaxial Strength } \\
\text { Data. }\end{array}$ & $\begin{array}{l}\text { Multi-axial strength data is obtained from } \\
\text { Section 5.1.4.3, Mechanical testing, and } \\
5.2 .1 \text {, Whole graphite core and component } \\
\text { behavior models. }\end{array}$ \\
\hline C. 11.03 .12 & GA & Graphite Fatigue Data. & $\begin{array}{l}\text { No reference to fatigue data in the } \\
\text { Graphite Technology Development Plan. }\end{array}$ \\
\hline C. 11.03 .13 & GA & $\begin{array}{l}\text { Graphite Mechanical Properties } \\
\text { Data. }\end{array}$ & $\begin{array}{l}\text { The majority of the mechanical properties } \\
\text { data is obtained from mechanical testing as } \\
\text { identified in Section 5.1.4.3. }\end{array}$ \\
\hline C. 11.03 .14 & GA & $\begin{array}{l}\text { Graphite Irradiation Induced } \\
\text { Dimensional Change Data. }\end{array}$ & $\begin{array}{l}\text { Irradiation induced dimension change data } \\
\text { is gathered from the physical testing } \\
\text { Section 5.1.4.1 (specifically, subsection } \\
\text { Irradiation Dimensional Change). }\end{array}$ \\
\hline C. 11.03 .15 & GA & $\begin{array}{l}\text { Graphite Irradiation Induced } \\
\text { Creep Data. }\end{array}$ & $\begin{array}{l}\text { Irradiation induced creep data is gathered } \\
\text { from the AGR experiment as identified in } \\
\text { Section 5.1.31. }\end{array}$ \\
\hline C. 11.03 .16 & GA & $\begin{array}{l}\text { Graphite Thermal Properties } \\
\text { Data. }\end{array}$ & $\begin{array}{l}\text { Thermal properties data is obtained from } \\
\text { thermal testing per Section 5.1.4.2. }\end{array}$ \\
\hline C. 11.03 .17 & GA & $\begin{array}{l}\text { Graphite Fracture Mechanics } \\
\text { Data. }\end{array}$ & $\begin{array}{l}\text { Fracture toughness data is obtained from } \\
\text { mechanical testing per Section 5.1.4.3. }\end{array}$ \\
\hline
\end{tabular}


Table 15. (continued).

\begin{tabular}{|c|c|c|c|}
\hline Number & Vendor & Description & Status \\
\hline C. 11.03 .18 & GA & Graphite Corrosion Data. & $\begin{array}{l}\text { The only corrosion data identified is } \\
\text { oxidation as covered under Section } 5.1 .4 \text {, } \\
\text { Table } 4 \text {, which addresses the oxidation } \\
\text { behavior in the presence of impurities }(02 \text {, } \\
\left.\mathrm{CO}_{2}, \mathrm{H}_{2} \mathrm{O}\right) \text {. }\end{array}$ \\
\hline C.11.03.19 & GA & $\begin{array}{l}\text { Graphite Corrosion Data for } \\
\text { Methods Validation. }\end{array}$ & $\begin{array}{l}\text { The only corrosion data identified is } \\
\text { oxidation as covered under Section } 5.1 .4 \text {, } \\
\text { Table } 4 \text {, which addresses the oxidation } \\
\text { behavior in the presence of impurities }(02 \text {, } \\
\left.\mathrm{CO}_{2}, \mathrm{H}_{2} \mathrm{O}\right) \text {. }\end{array}$ \\
\hline C. 11.03 .20 & GA & $\begin{array}{l}\text { Graphite Destructive and } \\
\text { Nondestructive Examination } \\
\text { Data. }\end{array}$ & $\begin{array}{l}\text { Examination data, both destructive and } \\
\text { nondestructive, is gathered per } \\
\text { Section 5.1.4.1, Physical Testing. }\end{array}$ \\
\hline C. 11.03 .21 & GA & $\begin{array}{l}\text { Graphite Coke Source } \\
\text { Qualification. }\end{array}$ & $\begin{array}{l}\text { Source qualification for coke has been } \\
\text { identified (and costs) in the Graphite R\&D } \\
\text { test plan as a required activity but no } \\
\text { testing or detailed program activities are } \\
\text { identified. }\end{array}$ \\
\hline C. 11.03 .23 & GA & $\begin{array}{l}\text { Graphite Oxidation Data for } \\
\text { Postulated Accidents. }\end{array}$ & $\begin{array}{l}\text { Section } 5.1 .4 \text {, Table } 4 \text { addresses the } \\
\text { oxidation behavior in the presence of } \\
\text { impurities }\left(\mathrm{O}_{2}, \mathrm{CO}_{2}, \mathrm{H}_{2} \mathrm{O}\right) \text { for acute } \\
\text { accident and chronic normal operations. }\end{array}$ \\
\hline C. 16.00 .05 & GA & $\begin{array}{l}\text { Effective Conductivity of Core } \\
\text { Blocks. }\end{array}$ & $\begin{array}{l}\text { Thermal Conductivity of graphite is } \\
\text { covered in Section 5.1.4.2, Thermal } \\
\text { Testing. }\end{array}$ \\
\hline N.07.05.05 & GA & $\begin{array}{l}\text { H-451 Graphite Oxidation Rates } \\
\text { (Air). }\end{array}$ & $\begin{array}{l}\text { Section } 5.1 .4 \text {, Table } 4 \text { addresses the } \\
\text { oxidation behavior in the presence of } \\
\text { impurities }\left(\mathrm{O}_{2}, \mathrm{CO}_{2}, \mathrm{H}_{2} \mathrm{O}\right)\end{array}$ \\
\hline N.07.05.06 & GA & $\begin{array}{l}\text { Graphite Non-combustibility } \\
\text { Demonstration. }\end{array}$ & $\begin{array}{l}\text { Graphite Non-combustibility is being } \\
\text { addressed through the INL/EXT-11-21097 } \\
\text { 'HTGR Dust Safety Issues and Needs for } \\
\text { R\&D' - Rev 0, 6-27-2011 }\end{array}$ \\
\hline N.07.05.10 & GA & $\begin{array}{l}\text { Graphite Corrosion Rates } \\
\text { (Groundwater). }\end{array}$ & $\begin{array}{l}\text { The only corrosion data identified is } \\
\text { oxidation which is covered under } \\
\text { Section } 5.1 .4 \text {, Table } 4 \text {. }\end{array}$ \\
\hline N.07.05.13 & GA & Chemical Impurities in Graphite. & $\begin{array}{l}\text { All major grades of graphite that are } \\
\text { candidates for use in the NGNP will need } \\
\text { to meet the maximum impurity levels } \\
\text { specified in ASTM Standard } 7219 \text {. The } \\
\text { chemical impurity levels are determined at } \\
\text { the billet level so that they are known } \\
\text { before physical, thermal, and mechanical } \\
\text { tests are performed. }\end{array}$ \\
\hline
\end{tabular}




\subsubsection{Additional Technological Development}

The R\&D graphite test plans provide a baseline estimate for performing the required graphite R\&D for the NGNP. This section identifies longer-term issues that would impact the longer R\&D program needed for ultimate commercialization of the HTGR technology. This section identifies some programs that are being proposed to be performed but there is no specific test plan or schedule identified for this work. These are effectively follow-on activities to be performed at a later date

\section{Graphite Acquisition Plan}

Full commercialization of the HTGR graphite technology in the long term requires a more complete evaluation of the processing route and raw material (e.g., coke source) constituent's influence on graphite behavior.

\section{Graphite Disposition and Recycle Options}

There is currently no federal guidance on recycling irradiated graphite. Recycling irradiated graphite will depend on a number of factors, including the number of HTGRs (volume of graphite generated), ability to decontaminate irradiated graphite, performance of recycled graphite, and total cost of recycling.

Once a successful technology is developed for decontaminating graphite, the primary issue for recycling will be irradiation performance of the recycled graphite. A new qualification program will be necessary to validate the performance of this recycled graphite source, either for reuse of blocks or reconstituted material.

\subsubsection{Risk Analysis and PIRTs}

The NGNP risks database (NGNP_RMS_V2_D_15SEP2010.mdb) identifies a number of risks and PIRTs associated with the reactor core graphite. Table 16 identifies how those risks are mitigated by the graphite R\&D test plans. The test references given below are taken from PLN-2497, "NGNP Graphite Technology Development Research and Development Plan" (Rev. 1).

Table 16. Risk and PIRT analysis.

\begin{tabular}{|c|c|c|c|}
\hline Risk Title & Description & Associated PIRTs & Status \\
\hline $\begin{array}{l}\text { 477. Consistency in } \\
\text { Graphite Properties } \\
\text { in Reactor Core and } \\
\text { Core Structure. }\end{array}$ & $\begin{array}{l}\text { As new graphite's } \\
\text { are developed and } \\
\text { produced their } \\
\text { properties will be } \\
\text { inconsistent with } \\
\text { current stocks of } \\
\text { graphite being tested } \\
\text { and qualified for the } \\
\text { NGNP. }\end{array}$ & $\begin{array}{l}\text { 6944-232. Consistency in } \\
\text { graphite quality over the } \\
\text { lifetime of the reactor fleet. } \\
6944-231 . \text { Statistical variation } \\
\text { of nonirradiated properties. }\end{array}$ & $\begin{array}{l}\text { This is the main component of the } \\
\text { Advanced Graphite Capsule (AGC) } \\
\text { program, in which multiple graphite } \\
\text { types are being irradiated in order to } \\
\text { understand the changes to the } \\
\text { overall performance of the graphite } \\
\text { during irradiation. }\end{array}$ \\
\hline $\begin{array}{l}\text { 499. Distortion of } \\
\text { Core Structure } \\
\text { Materials by } \\
\text { Radiation. }\end{array}$ & $\begin{array}{l}\text { The life of key core } \\
\text { structural } \\
\text { components } \\
\text { associated with } \\
\text { graphite } \\
\text { performance under } \\
\text { irradiation at high } \\
\text { temperatures may be } \\
\text { limited or reduced. }\end{array}$ & $\begin{array}{l}6944-260(+) . \text { Channel distortion. } \\
6944-4 \text {. Core flow distribution } \\
\text { changes due to graphite } \\
\text { irradiation. } \\
6944-273(+) . \text { Increased bypass } \\
\text { coolant flow channels by break, } \\
\text { distortion, etc. } \\
6944-249(+) . \text { Irradiation-induced } \\
\text { change in graphite pore structure. }\end{array}$ & $\begin{array}{l}\text { The graphite irradiation program } \\
\text { (AGC1-AGC6 and high } \\
\text { temperature vessel (HTV) HTV1- } \\
\text { HTV2) consists of eight irradiations } \\
\text { that span the proposed temperature } \\
\text { and dose envelope for a prismatic } \\
\text { NGNP and the first half of a pebble } \\
\text { bed design dose. }\end{array}$ \\
\hline
\end{tabular}


Table 16. (continued).

\begin{tabular}{|c|c|c|c|}
\hline Risk Title & Description & Associated PIRTs & Status \\
\hline $\begin{array}{l}\text { 501. Reactor Core } \\
\text { Graphite } \\
\text { Qualification. }\end{array}$ & $\begin{array}{l}\text { The reactor core } \\
\text { graphite is not } \\
\text { qualified and may } \\
\text { require a series of } \\
\text { irradiation tests } \\
\text { necessary for } \\
\text { qualification. }\end{array}$ & $\begin{array}{l}\text { 6944-135. Fluence effect on } \\
\text { transport in graphite } \\
6944-129 . \text { Fission product } \\
\text { transport through fuel block } \\
\text { 6944-128. Fuel block } \\
\text { permeability, tortuosity. }\end{array}$ & $\begin{array}{l}\text { The graphite irradiation program } \\
\text { (AGC1-AGC6 and HTV1-HTV2) } \\
\text { consists of eight irradiations that } \\
\text { span the proposed temperature and } \\
\text { dose envelope for a prismatic } \\
\text { NGNP and the first half of a pebble } \\
\text { bed design dose. } \\
\text { Fission product transport is tested } \\
\text { under the fuel AGR program. }\end{array}$ \\
\hline $\begin{array}{l}\text { 503. Effect of air } \\
\text { Ingress On Reactor } \\
\text { Core \& Core } \\
\text { Structure. }\end{array}$ & $\begin{array}{l}\text { Effect of air Ingress } \\
\text { On Reactor Core } \\
\text { and Core Structure. }\end{array}$ & $\begin{array}{l}\text { 6944-137. Air attack on graphite. } \\
\text { 6944-280. Chemical attack. } \\
\text { 6944-110. Core (steam) oxidation } \\
\text { modeling. } \\
\text { 6944-67. Core oxidation. } \\
\text { 6944-63. Heat transfer } \\
\text { correlations for mixed gases in } \\
\text { core. } \\
\text { 6944-68. Rx cavity-to-reactor } \\
\text { vessel air ingress. }\end{array}$ & $\begin{array}{l}\text { Activities for predicting the long- } \\
\text { term, chronic (diffusion controlled) } \\
\text { oxidation rate of graphite are } \\
\text { ongoing. A systematic effort is } \\
\text { being pursued to characterize } \\
\text { fundamental material properties that } \\
\text { determine oxidation behavior } \\
\text { (chemical reactivity and diffusion } \\
\text { transport) of candidate NGNP } \\
\text { graphite materials. This activity } \\
\text { considers each of the possible } \\
\text { oxidant species }\left(\mathrm{O}_{2}, \mathrm{CO}_{2}, \mathrm{H}_{2} \mathrm{O}\right) \\
\text { that will be present in the coolant } \\
\text { helium and covers normal } \\
\text { operation, transient, and acute } \\
\text { (accident) conditions. }\end{array}$ \\
\hline $\begin{array}{l}\text { 502. Effect of Water } \\
\text { Ingress On Reactor } \\
\text { Core \& Core } \\
\text { Structure. }\end{array}$ & $\begin{array}{l}\text { Effect of Water } \\
\text { Ingress on Core } \\
\text { Structure. }\end{array}$ & $\begin{array}{l}\text { 6944-280. Chemical attack. } \\
6944-110 . \text { Core (steam) oxidation } \\
\text { modeling. } \\
\text { 6944-67. Core oxidation. } \\
\text { 6944-108. Fuel performance with } \\
\text { oxygen attack. } \\
\text { 6944-107. Mechanisms for water } \\
\text { or steam ingress from coolers. } \\
\text { 6944-138. Steam attack on } \\
\text { graphite. }\end{array}$ & $\begin{array}{l}\text { Activities for predicting the long- } \\
\text { term, chronic (diffusion controlled) } \\
\text { oxidation rate of graphite are } \\
\text { ongoing. A systematic effort is } \\
\text { being pursued to characterize } \\
\text { fundamental material properties that } \\
\text { determine oxidation behavior } \\
\text { (chemical reactivity and diffusion } \\
\text { transport) of candidate NGNP } \\
\text { graphite materials. This activity } \\
\text { considers each of the possible } \\
\text { oxidant species }\left(\mathrm{O}_{2}, \mathrm{CO}_{2}, \mathrm{H}_{2} \mathrm{O}\right) \\
\text { that will be present in the coolant } \\
\text { helium and covers normal } \\
\text { operation, transient, and acute } \\
\text { (accident) conditions. }\end{array}$ \\
\hline $\begin{array}{l}\text { 552. Failure } \\
\text { Mechanisms for } \\
\text { Design Criteria, } \\
\text { Creep, Fatigue. }\end{array}$ & $\begin{array}{l}\text { Failure Mechanisms } \\
\text { for Design Criteria, } \\
\text { Creep, Fatigue. }\end{array}$ & $\begin{array}{l}\text { 6944-283. External (applied) } \\
\text { loads. } \\
6944-118 . \text { Material/structure } \\
\text { properties. } \\
6944-275(+) . \text { Outlet plenum } \\
\text { collapse. }\end{array}$ & $\begin{array}{l}\text { The AGC experiment is designed to } \\
\text { provide irradiation creep rates for } \\
\text { moderate doses and higher } \\
\text { temperatures of leading graphite } \\
\text { types that will be used in the NGNP } \\
\text { reactor design. }\end{array}$ \\
\hline
\end{tabular}


Table 16. (continued).

\begin{tabular}{|c|c|c|c|}
\hline Risk Title & Description & Associated PIRTs & Status \\
\hline $\begin{array}{l}\text { 553. Uncertainty of } \\
\text { extrapolation of } \\
\text { existing to higher } \\
\text { temperatures in } \\
\text { reactor core and } \\
\text { core structure. }\end{array}$ & $\begin{array}{l}\text { Uncertainty of } \\
\text { extrapolation of } \\
\text { existing data to } \\
\text { higher temperatures. }\end{array}$ & 6944-286. Graphite temperatures. & $\begin{array}{l}\text { The AGC program provides data on } \\
\text { graphite physical, thermal, and } \\
\text { mechanical behavior as a function } \\
\text { of irradiation temperature and } \\
\text { neutron fluence. The data is used to } \\
\text { model the graphite core as per } \\
\text { Section } 5.2 .1 \text { Whole graphite core } \\
\text { and component behavior models, } \\
\text { and 5.2.2 Macroscale materials } \\
\text { behavior models. }\end{array}$ \\
\hline $\begin{array}{l}\text { 555. Working Fluid } \\
\text { Impact on Vessel } \\
\text { Internals (Coolant } \\
\text { Flow } \\
\text { Viscosity/Friction, } \\
\text { Corrosion and } \\
\text { Erosion). }\end{array}$ & $\begin{array}{l}\text { Working Fluid } \\
\text { Impact on Vessel } \\
\text { Internals (Coolant } \\
\text { Flow } \\
\text { Viscosity/Friction). }\end{array}$ & $\begin{array}{l}\text { 6944-4. Core flow distribution } \\
\text { changes due to graphite } \\
\text { irradiation. } \\
\text { 6944-122. Gas composition. } \\
\text { 6944-246. Graphite dust } \\
\text { generation. } \\
\text { 6944-247. Potential changes in } \\
\text { irradiated graphite emissivity. } \\
\text { 6944-248. Tribology of graphite } \\
\text { in (impure) helium environment. }\end{array}$ & $\begin{array}{l}\text { Section } 5.2 .1 \text {, Whole graphite core } \\
\text { and component behavior models; } \\
\text { models will take core physics and } \\
\text { thermohydraulic inputs for point } \\
\text { dose and temperature values and } \\
\text { apply graphite material behavior } \\
\text { models to calculate the changes in } \\
\text { properties with neutron dose, } \\
\text { temperature, and oxidative weight } \\
\text { loss. Core and component-scale } \\
\text { models will allow designers to } \\
\text { predict core and core block (e.g., } \\
\text { reflector or fuel element) } \\
\text { dimensional distortion, component } \\
\text { stresses, residual strength, and } \\
\text { probability of failure during normal } \\
\text { or off-normal conditions. }\end{array}$ \\
\hline
\end{tabular}

\subsubsection{Nongraphite Core Structures (Ceramic Composites)}

No R\&D activities are currently being performed at INL on ceramic composites. However, a Composite Technology Development Plan (ORNL/TM-2009/185 Rev. 3, June 2010) has been produced by ORNL, sponsored by the DOE under contract DE-AC05-00OR22725.

The ORNL Composite Technology Development Plan was developed to (1) review the knowledge base that exists globally for the application of ceramic composites in nuclear and high temperature extreme environments with emphasis on radiation effects, (2) review ceramic composite materials needs and component design requirements based on studies performed by U.S. plant vendors/designers, (3) provide recommendations for licensing strategies and needs, primarily through development of materials/test specifications and design rules; (4) identify needs for composite property determinations for qualification of specific materials for use in HTGR/VHTR, and (5) propose a plan to generate the information needed for operational licensing of an HTGR/VHTR reactor design with composite control rods and other in-vessel components.

Ceramic composites that are candidates for HTGR/VHTR application are certain grades of carbon fiber-carbon matrix composites $(\mathrm{C} / \mathrm{C}$ composites) and $\mathrm{SiC} / \mathrm{SiC}$ composites. Ceramic composite materials are potential alternatives to heat resistant metallic alloys for many components in HTGRs and the only viable option for some components in the higher temperature and high fluence follow-on NOAK reactors. 


\subsubsection{Ceramic Composites Status}

The Composite Technology Development Plan (ORNL/TM-2009/185, Rev. 3, June 2010) identifies that during FY 2005 through 2008, the technical feasibility of using composite materials in HTGR/VHTR was critically examined in DOE's NGNP Composite R\&D Program. The main findings included (1) the environmental challenges (nuclear and oxidative corrosion) do not appear to degrade the performance of these materials in a significant manner; (2) the normal reactor operating condition or off-normal events, will not be seriously limited by properties of these materials; (3) the driving need for these materials ranges from a potential economic benefit to a clear technical need, depending on design decisions, which, at that point, had not been determined; and (4) the design code development and licensing are the critical barriers limiting the use of these materials in nuclear systems.

The General Atomics report, "Effect of Reactor Outlet Helium Temperature on the Need for Composites in the NGNP" (911175, Rev. 0, November 6, 2009), identifies the need for ceramic composites for reactor core internals as the reactor outlet temperature increases. The report detailed a study where the reactor outlet temperature was varied from 700 to $950^{\circ} \mathrm{C}$ in $50^{\circ} \mathrm{C}$ increments. Reactor component temperatures were estimated for normal operation at $100 \%$ power and for pressurized conduction cooldown (PCC) and depressurized conduction cooldown (DCC) conditions. The conduction cooldown cases were for $600 \mathrm{MW}(\mathrm{t})$ reactor with $6.6 \mathrm{w} / \mathrm{cc}$ average power density. Some of the conclusions regarding ceramic composites required for components were:

- For hot duct thermal barrier cover plates ceramic composites are needed for reactor outlet helium temperatures at or above $900^{\circ} \mathrm{C}$

- The upper core restraint (UCR) elements should be made from ceramic composites because the temperatures that result from the decay heat are too high for use of metallic materials during a PCC event for all reactor outlet helium temperatures evaluated

- The control rod and reserve shutdown material guide tubes need to be made of ceramic composite for reactor outlet temperatures at or above $850^{\circ} \mathrm{C}$

- The inner control rod structural elements should be made from ceramic composite material because the conduction cooldown temperatures are too high for use of metals for all reactor outlet helium temperatures considered in the study

- It was considered unlikely that ceramic composite UCR elements can be developed and qualified on a schedule that would make them available for NGNP startup in 2021.

Figure 5 shows material selections for a $600 \mathrm{MW}(\mathrm{t})$ NGNP high temperature reactor internals components as reactor outlet temperatures increase (these are GA recommendations). 


\begin{tabular}{|c|c|c|c|c|c|c|c|c|c|c|c|c|c|}
\hline \multirow{2}{*}{ Comp } & \multirow{2}{*}{$\begin{array}{c}\text { Temperature } \\
\text { Condition }\end{array}$} & \multicolumn{12}{|c|}{ Reactor Outiot Helium Temperature and Materiai Selection' } \\
\hline & & $700 \mathrm{C}$ & Mat'I Sel & $750 \mathrm{C}$ & Mat'I Sel & $800 \mathrm{C}$ & Mat'I Sel & $850 \mathrm{C}$ & Mari Sol & $900 \mathrm{C}$ & Mat'I Sol & $950 \mathrm{C}$ & Matil Sol \\
\hline Inner $\mathrm{CR}^{2}$ & $\begin{array}{l}\text { Normal Op } \\
\text { PCCD Max } \\
\text { DCCD Max }\end{array}$ & $\begin{array}{c}788 \\
1,159 \\
1,413 \\
\end{array}$ & $\begin{array}{l}\mathrm{C}-\mathrm{C} \text { or } \mathrm{SiC}- \\
\mathrm{SiC}\end{array}$ & $\begin{array}{c}808 \\
1.164 \\
1.418 \\
\end{array}$ & $\begin{array}{l}\mathrm{C}-\mathrm{C} \text { or } \mathrm{SiC}- \\
\mathrm{SiC}\end{array}$ & $\begin{array}{c}832 \\
1,169 \\
1.463 \\
\end{array}$ & $\begin{array}{l}\text { C.C or SIC- } \\
\text { SiC }\end{array}$ & $\begin{array}{c}850 \\
1.174 \\
1.428 \\
\end{array}$ & $\begin{array}{l}\mathrm{C}-\mathrm{C} \text { or } \mathrm{SiC} \text {. } \\
\text { SiC }\end{array}$ & $\begin{array}{c}871 \\
1,179 \\
1.433 \\
\end{array}$ & $\begin{array}{l}\mathrm{C}-\mathrm{C} \text { or } \mathrm{SiC}- \\
\mathrm{SiC}\end{array}$ & $\begin{array}{r}894 \\
1,184 \\
1.438 \\
\end{array}$ & $\begin{array}{l}\text { C.C or } \\
\text { SiC-SiC }\end{array}$ \\
\hline Outer $\mathrm{CR}^{2}$ & $\begin{array}{l}\text { Normal Op } \\
\text { PCCD Max } \\
\text { DCCD Max }\end{array}$ & $\begin{array}{l}420 \\
924 \\
975 \\
\end{array}$ & $\begin{array}{c}\mathrm{C}-\mathrm{C} \text { or } \mathrm{SiC}- \\
\mathrm{SiC}\end{array}$ & $\begin{array}{l}440 \\
929 \\
980 \\
\end{array}$ & $\begin{array}{c}\mathrm{C}-\mathrm{C} \text { or SiC- } \\
\mathrm{SiC}\end{array}$ & $\begin{array}{l}464 \\
934 \\
980 \\
\end{array}$ & $\begin{array}{c}\text { C. } \mathrm{C}_{\text {or } \mathrm{SiC}} \\
\mathrm{SiC}\end{array}$ & $\begin{array}{l}482 \\
939 \\
990 \\
\end{array}$ & $\begin{array}{c}\mathrm{C}-\mathrm{C} \text { or SiC. } \\
\mathrm{SiC}\end{array}$ & $\begin{array}{l}503 \\
944 \\
895 \\
\end{array}$ & $\begin{array}{c}\mathrm{C}-\mathrm{C} \text { or SiC- } \\
\text { SiC }\end{array}$ & $\begin{array}{c}526 \\
1,129 \\
1,000 \\
\end{array}$ & $\begin{array}{l}\text { C-C or } \\
\text { SiC-SiC }\end{array}$ \\
\hline $\begin{array}{l}\text { CR \& RSM } \\
\text { Guide } \\
\text { Tubes }\end{array}$ & $\begin{array}{l}\text { Normal Op } \\
\text { PCCD Max } \\
\text { DCCD Max }\end{array}$ & $\begin{array}{l}346 \\
928 \\
438 \\
\end{array}$ & Hast X & $\begin{array}{l}346 \\
933 \\
418 \\
\end{array}$ & Hast X & $\begin{array}{l}346 \\
638 \\
423 \\
\end{array}$ & Hast X & $\begin{array}{l}346 \\
943 \\
428 \\
\end{array}$ & $\begin{array}{c}\mathrm{C}-\mathrm{C} \text { or SIC- } \\
\text { SiC }\end{array}$ & $\begin{array}{l}346 \\
948 \\
433 \\
\end{array}$ & $\begin{array}{c}\mathrm{C}-\mathrm{C} \text { or SiC- } \\
\text { SiC }\end{array}$ & $\begin{array}{l}346 \\
953 \\
438 \\
\end{array}$ & $\begin{array}{l}\text { C-C or } \\
\text { SiC-SiC }\end{array}$ \\
\hline UCR & $\begin{array}{l}\text { Normal Op } \\
\text { PCCD Max } \\
\text { DCCD Max }\end{array}$ & $\begin{array}{c}346 \\
1,023 \\
599 \\
\end{array}$ & $\begin{array}{c}\mathrm{C}-\mathrm{C} \text { or SiC- } \\
\text { SiC }\end{array}$ & $\begin{array}{c}346 \\
1.028 \\
604 \\
\end{array}$ & $\begin{array}{c}\text { C-C or SiC- } \\
\text { SiC }\end{array}$ & $\begin{array}{c}346 \\
1.033 \\
609 \\
\end{array}$ & $\begin{array}{l}\text { C-C or SiC. } \\
\text { SiC }\end{array}$ & $\begin{array}{c}346 \\
1.038 \\
614 \\
\end{array}$ & $\begin{array}{c}\mathrm{C}-\mathrm{C} \text { or } \mathrm{SiC} \text {. } \\
\mathrm{SiC}\end{array}$ & $\begin{array}{c}346 \\
1,043 \\
619 \\
\end{array}$ & $\begin{array}{c}\mathrm{C}-\mathrm{C} \text { or } \mathrm{SIC}- \\
\mathrm{SiC}\end{array}$ & $\begin{array}{c}348 \\
1,048 \\
624 \\
\end{array}$ & $\begin{array}{l}\text { C-C or } \\
\text { SiC-SiC }\end{array}$ \\
\hline UPS T/B & $\begin{array}{l}\text { Normal Op } \\
\text { PCCD Max } \\
\text { DCCD Max }\end{array}$ & $\begin{array}{l}318 \\
872 \\
450 \\
\end{array}$ & Hast X & $\begin{array}{l}318 \\
877 \\
455 \\
\end{array}$ & Hast X & $\begin{array}{l}318 \\
882 \\
460 \\
\end{array}$ & Hast X & $\begin{array}{l}318 \\
887 \\
465 \\
\end{array}$ & Hast X & $\begin{array}{l}318 \\
892 \\
470 \\
\end{array}$ & Hast X & $\begin{array}{l}318 \\
897 \\
475 \\
\end{array}$ & Hast X \\
\hline $\begin{array}{l}\text { MCS Load } \\
\text { Pads }\end{array}$ & $\begin{array}{l}\text { Normal Op } \\
\text { PCCD Max } \\
\text { DCCD Max }\end{array}$ & $\begin{array}{l}615 \\
615 \\
615\end{array}$ & $\begin{array}{c}\text { Macor } \\
\text { Glass } \\
\text { Ceramic }\end{array}$ & $\begin{array}{l}653 \\
653 \\
653\end{array}$ & $\begin{array}{c}\text { Macor } \\
\text { Glass } \\
\text { Ceramic }\end{array}$ & $\begin{array}{l}692 \\
692 \\
692\end{array}$ & $\begin{array}{c}\text { Macor } \\
\text { Glass } \\
\text { Ceramic }\end{array}$ & $\begin{array}{l}730 \\
730 \\
730\end{array}$ & $\begin{array}{c}\text { Macor } \\
\text { Glass } \\
\text { Ceramic }\end{array}$ & $\begin{array}{l}769 \\
769 \\
769\end{array}$ & $\begin{array}{c}\text { Macor } \\
\text { Glass } \\
\text { Ceramic }\end{array}$ & $\begin{array}{l}807 \\
807 \\
807\end{array}$ & $\begin{array}{c}\text { Macor } \\
\text { Glass } \\
\text { Ceramic }\end{array}$ \\
\hline $\begin{array}{l}\text { Hot Duct } \\
\text { T/B }\end{array}$ & $\begin{array}{l}\text { Normal Op } \\
\text { Long Term Peak } \\
\text { Short Term Peak } \\
\text { PCCD Max } \\
\text { DCCD Max }\end{array}$ & $\begin{array}{l}699 \\
734 \\
766 \\
699 \\
699 \\
\end{array}$ & $800 \mathrm{H}$ & $\begin{array}{l}749 \\
486 \\
820 \\
749 \\
749 \\
\end{array}$ & Hast X & $\begin{array}{l}798 \\
837 \\
874 \\
798 \\
798 \\
\end{array}$ & Hast X & $\begin{array}{l}848 \\
837 \\
923 \\
848 \\
848 \\
\end{array}$ & Hast X & $\begin{array}{l}898 \\
937 \\
972 \\
898 \\
898 \\
\end{array}$ & $\begin{array}{c}\mathrm{C}-\mathrm{C} \text { or SiC- } \\
\text { SiC }\end{array}$ & $\begin{array}{c}948 \\
986 \\
1,022 \\
948 \\
948 \\
\end{array}$ & $\begin{array}{l}\text { C-C or } \\
\text { SiC-sic }\end{array}$ \\
\hline LPS T/B & $\begin{array}{l}\text { Normal Op } \\
\text { Long Term Peak } \\
\text { Short Term Peak } \\
\text { PCCD Max } \\
\text { DCCD Max }\end{array}$ & $\begin{array}{l}630 \\
664 \\
697 \\
630 \\
630 \\
\end{array}$ & $800 \mathrm{H}$ & $\begin{array}{l}670 \\
707 \\
742 \\
670 \\
670 \\
\end{array}$ & $800 \mathrm{H}$ & $\begin{array}{l}711 \\
750 \\
786 \\
711 \\
711 \\
\end{array}$ & $800 \mathrm{H}$ & $\begin{array}{l}752 \\
791 \\
826 \\
752 \\
752 \\
\end{array}$ & Hast X & $\begin{array}{l}792 \\
831 \\
867 \\
792 \\
792 \\
\end{array}$ & Hast X & $\begin{array}{l}833 \\
871 \\
907 \\
833 \\
833 \\
\end{array}$ & Hast X \\
\hline $\begin{array}{l}\text { scs } \\
\text { Entrance } \\
\text { Tubes }\end{array}$ & $\begin{array}{l}\text { Normal Op } \\
\text { Long Term Peak } \\
\text { Short Term Peak } \\
\text { PCCD Max } \\
\text { DCCD Max }\end{array}$ & $\begin{array}{l}615 \\
664 \\
697 \\
615 \\
615 \\
\end{array}$ & $800 \mathrm{H}$ & $\begin{array}{l}653 \\
690 \\
724 \\
653 \\
653 \\
\end{array}$ & $800 \mathrm{H}$ & $\begin{array}{l}691 \\
730 \\
766 \\
691 \\
691 \\
\end{array}$ & $800 \mathrm{H}$ & $\begin{array}{l}729 \\
768 \\
804 \\
729 \\
729\end{array}$ & Hast X & $\begin{array}{l}768 \\
806 \\
842 \\
768 \\
768 \\
\end{array}$ & Hast X & $\begin{array}{l}8006 \\
844 \\
880 \\
806 \\
806\end{array}$ & Hast X \\
\hline $\operatorname{SCS} T / B$ & $\begin{array}{l}\text { Normal Op } \\
\text { PCCD Max } \\
\text { DCCD Max }\end{array}$ & $\begin{array}{l}350 \\
350 \\
350 \\
\end{array}$ & $800 \mathrm{H}$ & $\begin{array}{l}350 \\
350 \\
350 \\
\end{array}$ & $800 \mathrm{H}$ & $\begin{array}{l}350 \\
350 \\
350 \\
\end{array}$ & $800 \mathrm{H}$ & $\begin{array}{l}350 \\
350 \\
350 \\
\end{array}$ & $800 \mathrm{H}$ & $\begin{array}{l}350 \\
350 \\
350 \\
\end{array}$ & $800 \mathrm{H}$ & $\begin{array}{l}350 \\
350 \\
350 \\
\end{array}$ & $800 \mathrm{H}$ \\
\hline
\end{tabular}

Figure 5 shows material selections for a $600 \mathrm{MW}(\mathrm{t}) \mathrm{NGNP}$ high temperature reactor internals components as reactor outlet temperatures increase (these are GA recommendations).

\subsubsection{Design Data Needs}

Several DDNs are associated with the technological development of the NGNP ceramic composite program. These DDNs are presented in Table 17. ORNL has a generic R\&D ceramic composite development plan, but no specific test plans or schedule has been identified. The first three column references are from DDN documents (see 'References' section, numbers 15, 16 and 17).

Table 17. Ceramics composite DDNs.

\begin{tabular}{|l|l|l|l|}
\hline \multicolumn{1}{|c|}{ Number } & \multicolumn{1}{|c|}{ Vendor } & \multicolumn{1}{|c|}{ Description } & \multicolumn{1}{c|}{ Status } \\
\hline 2.3.1.1a & AREVA & $\begin{array}{l}\text { Control Rods: Thermal-physical properties Material } \\
\text { selection has not been performed yet although different } \\
\text { control rod material alternatives are being considered. } \\
\text { Later during conceptual design, a decision will be made. } \\
\text { Materials currently envisioned are C/C, SiC/SiC or } \\
\text { C/SiC composites. }\end{array}$ & No Tests have been identified. \\
\hline 2.3.1.1a & AREVA & Control Rods: Thermal-Physical Properties. & No Tests have been identified. \\
\hline 2.3.1.1b & AREVA & Control Rod: Mechanical Properties. & No Tests have been identified. \\
\hline 2.3.1.1c & AREVA & Control Rod: Fracture Properties. & No Tests have been identified. \\
\hline 2.3.1.1d & AREVA & Control Rod: Fatigue Strength. & No Tests have been identified. \\
\hline 2.3.1.1e & AREVA & $\begin{array}{l}\text { Control Rod: Oxidation Characteristics and Effects on } \\
\text { Material Properties. }\end{array}$ & No Tests have been identified. \\
\hline 2.3.1.1f & AREVA & Control Rod: Irradiation and Testing of Mockups. & No Tests have been identified. \\
\hline 2.3.1.1g & AREVA & $\begin{array}{l}\text { Control Rod: Development of Fabrication and } \\
\text { Qualification Methods. }\end{array}$ & No Tests have been identified. \\
\hline
\end{tabular}


Table 17.(continued)

\begin{tabular}{|c|c|c|c|}
\hline Number & Vendor & Description & Status \\
\hline 2.3.1.2 & AREVA & $\begin{array}{l}\text { Control Rods (solid ceramic composite control rod } \\
\text { without sheaths). }\end{array}$ & No Tests have been identified. \\
\hline 2.3.2.1 & AREVA & $\begin{array}{l}\text { Upper Core Restraints Study: thermal-physical } \\
\text { properties (K, CTE, Cp), mechanical properties } \\
\text { including multiaxial strength, fracture properties, fatigue } \\
\text { properties, behavior under oxidized atmosphere and } \\
\text { oxidation effects on properties, codification, and } \\
\text { materials. }\end{array}$ & No Tests have been identified. \\
\hline 2.3.2.1a & AREVA & Upper Core Restraints: Thermal-Physical Properties. & No Tests have been identified. \\
\hline 2.3.2.1b & AREVA & Upper Core Restraints: Mechanical Properties. & No Tests have been identified. \\
\hline $2.3 .2 .1 \mathrm{c}$ & AREVA & Upper Core Restraints: Fracture Properties. & No Tests have been identified. \\
\hline 2.3.2.1d & AREVA & Upper Core Restraints: Fatigue Strength. & No Tests have been identified. \\
\hline 2.3.2.1e & AREVA & $\begin{array}{l}\text { Upper Core Restraints: Oxidation Characteristics and } \\
\text { Effects on Material Properties. }\end{array}$ & No Tests have been identified. \\
\hline 2.3.2.1f & AREVA & $\begin{array}{l}\text { Upper Core Restraints: Irradiation and Testing of } \\
\text { Mockups. }\end{array}$ & No Tests have been identified. \\
\hline $2.3 .2 .1 \mathrm{~g}$ & AREVA & $\begin{array}{l}\text { Upper Core Restraints: Development of Fabrication and } \\
\text { Qualification Methods. }\end{array}$ & No Tests have been identified. \\
\hline 2.3 .3 .1 & AREVA & $\begin{array}{l}\text { Top Plenum Shroud Study: Thermal-physical properties } \\
\text { (K, CTE, Cp): Mechanical properties including } \\
\text { multiaxial strength: Fracture properties. }\end{array}$ & No Tests have been identified. \\
\hline 2.3 .4 .1 & AREVA & $\begin{array}{l}\text { Hot Gas Duct Liners Study: thermal-physical properties } \\
\text { (K, CTE, Cp), behavior under high temperature and } \\
\text { irradiation conditions. and behavior under oxidation. }\end{array}$ & No Tests have been identified. \\
\hline 2.3 .5 .1 & AREVA & $\begin{array}{l}\text { Core Support Insulation Blocks Study: thermal-physical } \\
\text { properties (K, CTE, Cp), behavior under high } \\
\text { temperature and irradiation conditions, and behavior } \\
\text { under oxidation. }\end{array}$ & No Tests have been identified. \\
\hline 2.3.6.1 & AREVA & $\begin{array}{l}\text { Ceramic Insulation Study: thermal-physical properties } \\
\text { (K, CTE, Cp), behavior under high temperature and } \\
\text { irradiation conditions, and behavior under oxidation. }\end{array}$ & No Tests have been identified. \\
\hline 2.3.6.1a & AREVA & Ceramic Insulation: Thermal-Physical Properties. & No Tests have been identified. \\
\hline 2.3.6.1b & AREVA & Ceramic Insulation: Mechanical Properties. & No Tests have been identified. \\
\hline $2.3 .6 .1 \mathrm{c}$ & AREVA & $\begin{array}{l}\text { Ceramic Insulation: Oxidation Characteristics and } \\
\text { Effects on Material Properties. }\end{array}$ & No Tests have been identified. \\
\hline HPS-04-04 & WEC & $\begin{array}{l}\text { Develop Method to Bond Alloy 230/Alloy 617/Similar } \\
\text { Materials to Silicon Carbide and other Ceramics. }\end{array}$ & No Tests have been identified. \\
\hline HTS-02-01 & WEC & $\begin{array}{l}\text { Ceramic/Composite Hx. Review Existing Technology } \\
\text { Data needed includes establishing requirements, } \\
\text { assessing current databases, and selecting vendor } \\
\text { organization(s) to facilitate further developmental } \\
\text { activities. }\end{array}$ & No Tests have been identified. \\
\hline HTS-02-02 & WEC & Ceramic/Composite Hx. Materials Properties Database. & No Tests have been identified. \\
\hline
\end{tabular}


Table 17.(continued)

\begin{tabular}{|c|c|c|c|}
\hline Number & Vendor & Description & Status \\
\hline HTS-02-03 & WEC & $\begin{array}{l}\text { Ceramic/Composite Hx. Design Methods Data needed, } \\
\text { including results of stress strain modeling, thermal } \\
\text { structural modeling, and failure probability under } \\
\text { postulated conditions. }\end{array}$ & No Tests have been identified. \\
\hline HTS-02-04 & WEC & $\begin{array}{l}\text { Ceramic/Composite Hx: performance verification data } \\
\text { needed, including all information required to establish } \\
\text { the empirical basis for IHX performance, life prediction, } \\
\text { durability, and acceptability of fabricated materials in } \\
\text { support of the ASME BPV Code Cases. }\end{array}$ & No Tests have been identified. \\
\hline HTS-02-05 & WEC & $\begin{array}{l}\text { Ceramic/Composite Hx. Manufacturing technology data } \\
\text { needed includes general data from the open literature } \\
\text { and specific test results required to provide the basis for } \\
\text { integrating a ceramic/composite IHX within and with a } \\
\text { metallic or composite pressure vessel plus piping } \\
\text { system. }\end{array}$ & No Tests have been identified. \\
\hline HTS-02-06 & WEC & Ceramic/composite Hx: codes and standards. & No Tests have been identified. \\
\hline N.11.02.25 & GA & $\begin{array}{l}\text { UCR: Effect of Low Level Irradiation on Composite } \\
\text { Materials. }\end{array}$ & No Tests have been identified. \\
\hline N.11.02.26 & GA & UCR: Composite Material Properties. & No Tests have been identified. \\
\hline N.11.02.27 & GA & $\begin{array}{l}\text { UCR: Effects on Composites of Primary He and } \\
\text { Temperature. }\end{array}$ & No Tests have been identified. \\
\hline N.11.02.28 & GA & $\begin{array}{l}\text { UCR: Composite Component Manufacturing Process } \\
\text { Development. }\end{array}$ & No Tests have been identified. \\
\hline N.11.03.53 & GA & $\begin{array}{l}\text { Control Rod: Effect of High Level Irradiation on } \\
\text { Composite Materials. }\end{array}$ & No Tests have been identified. \\
\hline N.11.03.54 & GA & Control Rod: Composite Material Properties. & No Tests have been identified. \\
\hline N.11.03.55 & GA & $\begin{array}{l}\text { Control Rod: Effects on Composites of Primary He \& } \\
\text { Temperature. }\end{array}$ & No Tests have been identified. \\
\hline N.11.03.56 & GA & $\begin{array}{l}\text { Control Rod: Composite Component Manufacturing } \\
\text { Process Development. }\end{array}$ & No Tests have been identified. \\
\hline
\end{tabular}

\subsubsection{Technology Development Roadmap}

A TDRM for NGNP R\&D Graphite test program, is shown in Appendix A.

\subsubsection{Section Summary}

There are two DDNs not being addressed by the graphite program. The first DDN relates to graphite fatigue data, of which there are no related tests. Fatigue data is required by ASME BPV code and as funding becomes available there are fatigue tests planned by the graphite program. The graphite program is utilizing the Generation IV Information Forum (GIF) to obtain fatigue data from the British and European Union experience in decommissioning of the their graphite reactors.

The second DDN is related to fabrication techniques which are not part of the scope of the R\&D activities identified in the Graphite Technology Development Plan. This is to be expected since the graphite program is focused on the properties of the graphite for the reactor core and not the fabrication process. 
Composite ceramics (as is graphite) are used as components in reactor core internals. As the reactor outlet temperature increases to $850^{\circ} \mathrm{C}$ (and above), the number of reactor components required to be made from ceramic composites increases significantly. During a conduction cooldown scenario, the decay heat is too high for use by metallic materials, possibly requiring the replacement of reactor components. No INL ceramic composite R\&D program exists to advance the development, codification, and licensing of ceramic components. If a ceramics composite program is not initiated in the very near future, it is unlikely that the ceramic composites will be available for NGNP startup in the 2021 time frame.

\subsection{High Temperature Steam Electrolysis}

High temperature steam electrolysis (HTSE) for the NGNP is the production of hydrogen using solid oxide electrolysis cells (SOECs).

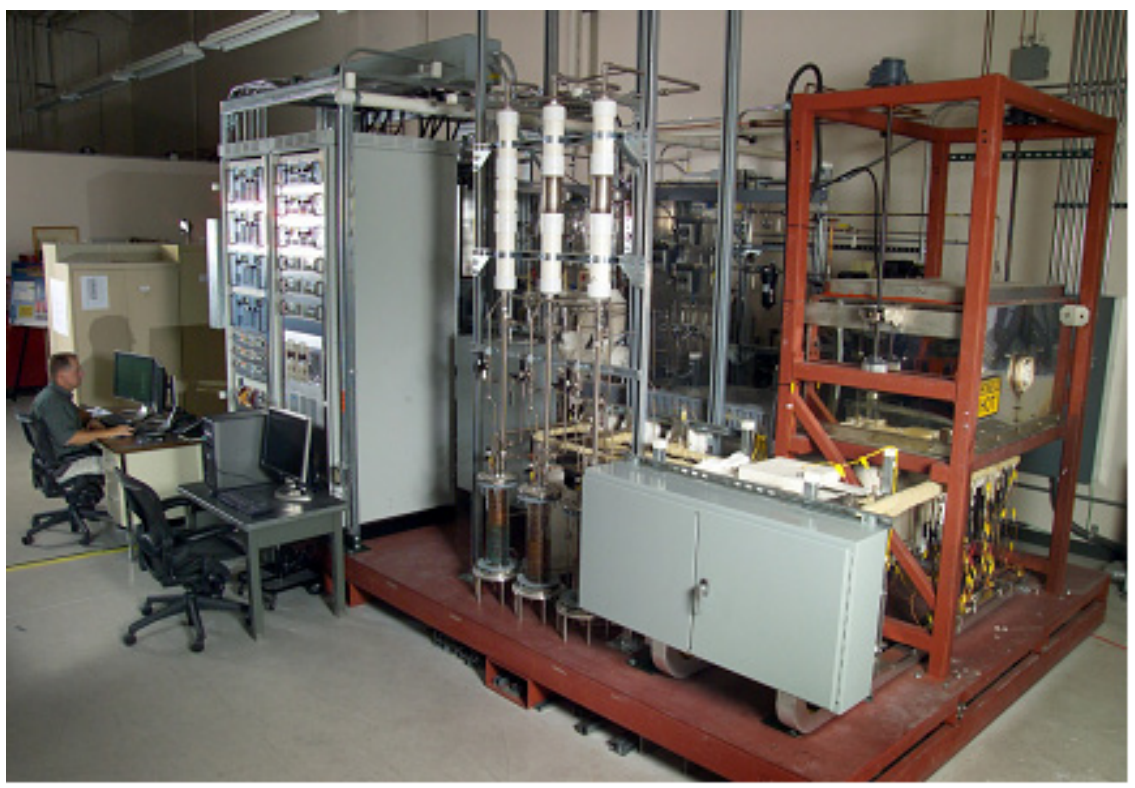

Figure 5. Overview of $15 \mathrm{~kW}$ INL Integrated Laboratory Scale (ILS) HTSE test facility.

\subsubsection{HTSE Design Description}

The SOEC is a solid-state electrochemical device consisting of an anode, cathode, and a solid oxygen ion-conducting electrolyte. In the planar configuration, these devices can be arranged in multiple-cell stacks with the individual cells joined by electrically conducting interconnects.

\subsubsection{Functions Performed}

The heat and electrical power from the reactor can be used to split water using the SOECs to create hydrogen and oxygen. The process heat from the reactor reduces the amount of electricity needed to split the water, thus increasing the efficiency of the process compared to low-temperature electrolysis.

\subsubsection{Research and Development Test Plans for HTSE}

The goals for the HTSE R\&D test plans are as follows:

- Understanding and mitigating long-term performance degradation in electrolytic cells 
- Developing cell and stack configurations that are amenable to large format cells

- Operating stacks at elevated pressures, nominally 3.5 to $5 \mathrm{MPa}$

- Designing and operating large-scale systems, including a pilot plant and demonstration module, which will show the engineering feasibility of this method of hydrogen production

The test plans are segregated by component to support NGNP deployment.

\subsubsection{Research and Development Tasks}

This section identifies the key R\&D activities required to advance the HTSE program's components through a number of technology readiness levels from a TRL-4 to a TRL-7. Each of the sections below is a key component to the test plan.

\section{HTSE Cells}

Demonstrate long-term operation of stacks with minimal degradation because of $\mathrm{Cr}, \mathrm{Si}$, or $\mathrm{Sr}$ migration, delamination of electrodes from electrolyte or corrosion of the interconnects. Operate a module for long durations $(1,000$ to $>10,000$ hours $)$.

\section{HTSE Heat Recuperator}

Demonstrate long-term operation of heat recuperators with minimal corrosion and leakage because of oxygen and hydrogen flows while operating at a pressure of 3 to $5 \mathrm{MPa}$. Demonstrate long-term operation of the modules with steam/hydrogen and air inlet temperatures of 300 to $400^{\circ} \mathrm{C}$ and outlet temperatures to the modules of 780 to $820^{\circ} \mathrm{C}$. Operate recuperators in the pilot plant for long durations $(5,000$ to $>10,000$ hours).

\section{HTSE Steam Superheater}

Demonstrate long-term operation of steam superheaters with minimal corrosion and leakage because of steam and hydrogen flows while operating at a pressure of 3 to $5 \mathrm{MPa}$. Demonstrate long-term operation of the modules with steam/hydrogen and air inlet temperatures of 300 to $400^{\circ} \mathrm{C}$ and outlet temperatures to the modules of 780 to $820^{\circ} \mathrm{C}$. Operate superheaters in the pilot plant for long durations $(5,000$ to $>10,000$ hours $)$.

\section{HTSE Sweep-gas and Oxygen Handling System}

Demonstrate long-term operation of sweep-gas and oxygen handling systems with minimal corrosion and leakage because of oxygen and hydrogen flows while operating at a pressure of 3 to $5 \mathrm{MPa}$.

Demonstrate long-term operation of the modules with steam/hydrogen and air inlet temperatures of 300 to $400^{\circ} \mathrm{C}$ and outlet temperatures to the modules of 780 to $820^{\circ} \mathrm{C}$. Operate sweep-gas and oxygen handling systems in the ILS for long durations (5,000 to $>10,000$ hours).

\section{HTSE Hydrogen Recycle System}

Demonstrate long-term operation of the hydrogen recycle systems with minimal corrosion and leakage because of steam and hydrogen flows. Demonstrate long-term operation of the modules with steam/hydrogen and air inlet temperatures of 300 to $400^{\circ} \mathrm{C}$ and outlet temperatures to the modules of 780 to $820^{\circ} \mathrm{C}$. Operate hydrogen recycle systems in the ILS for long durations (1,000 to $>10,000$ hours).

\section{HTSE Pressure Boundary System}

Demonstrate long-term operation of pressure boundary systems with minimal corrosion and leakage because of oxygen and hydrogen flows while operating at a pressure of 3 to $5 \mathrm{MPa}$. Demonstrate long- 
term operation of the modules with steam/hydrogen and air inlet temperatures of 300 to $400^{\circ} \mathrm{C}$ and outlet temperatures to the modules of 780 to $820^{\circ} \mathrm{C}$. Operate pressure boundary systems in the pilot plant for long durations $(5,000$ to $>10,000$ hours $)$.

\section{HTSE Instrumentation and Control System}

Demonstrate long-term operation of instrumentation and control systems with minimal corrosion and leakage because of oxygen and hydrogen flows while operating at a pressure of 3 to $5 \mathrm{MPa}$. Demonstrate long-term operation of the modules with steam/hydrogen and air inlet temperatures of 300 to $400^{\circ} \mathrm{C}$ and outlet temperatures to the modules of 780 to $820^{\circ} \mathrm{C}$. Operate instrumentation and control systems in the pilot plant for long durations (from 5000 to $>10,000$ hours).

\subsubsection{HTSE Status}

Current HTSE process development is at TRL-4, having completed successful bench-scale testing. An ILS test was also completed at the $15 \mathrm{~kW}$ scale, operating for 1,000 hours.

There are no vendor TRLs available; only an INL TRL as shown in Table 18.

Table 18. HTSE TRL determination by INL.

\begin{tabular}{|cc|}
\hline System & INL \\
\hline HTSE & 4 \\
\hline
\end{tabular}

The ILS was operated at ambient pressure and therefore not at a relevant environment, as required to achieve TRL-5 (experimental scale). A TRL-5 will be achieved when multicell stacks are tested at approximately $1 \mathrm{MPa}$ - anticipated in 2012 .

At present, the single largest challenge for the HTSE program is the unacceptable level of performance degradation of the SOECs. A reasonable target degradation level for long-term operation is $0.5 \% / \mathrm{khr}$. At this degradation level, capital costs associated with hydrogen production become small compared to operating costs, since the SOECs would only have to be changed out after approximately 40,000 hours ( every 5 years), allowing for a total degradation of $20 \%$.

\subsubsection{Design Data Needs}

Several DDNs are associated with the technological development of the NGNP HTSE. Documents referenced in Table 18 are from the High Temperature Steam Electrolysis Test Plans (INL/EXT-1019125, Rev. 0, June 16, 2010) and PLN-3604, "High Temperature Steam Electrolysis Technical Program Plan" (Rev. 0, March 4, 2011). The first three column references are from DDN documents (see 'References' section, numbers 15, 16 and 17).

Table 19. HTSE DDNs.

\begin{tabular}{|cccc|}
\hline Number & Vendor & Description & Status \\
\hline N.44.01.01 & GA & $\begin{array}{l}\text { Catalyst activity and lifespan as a function of } \\
\text { temperature and system pressure. }\end{array}$ & $\begin{array}{l}\text { All component tests are based on } \\
\text { operational lifespan at differing } \\
\text { temperatures and pressures. }\end{array}$ \\
\hline
\end{tabular}


Table 19. (continued).

\begin{tabular}{|c|c|c|c|}
\hline Number & Vendor & Description & Status \\
\hline N.44.03.01 & GA & $\begin{array}{l}\mathrm{H} 2 \text { permeability: } \mathrm{H} / \mathrm{H} 2 \text { separation factor and } \\
\text { membrane life. }\end{array}$ & $\begin{array}{l}\text { H2 permeability will be } \\
\text { developed as a part of 'HTSE } \\
\text { Hydrogen Recycle System'. } \\
\text { Membrane life is included in the } \\
\text { 'HTSE Cells" development. HI/H } \\
\text { separation relates to a down } \\
\text { selected technology that is no } \\
\text { longer part of the baseline. }\end{array}$ \\
\hline N.45.01.01 & GA & $\begin{array}{l}\text { Basic data on ionic conductivity, ohmic loss, } \\
\text { material stability at high temperature, structural } \\
\text { properties, corrosion resistance, and thermal } \\
\text { properties. Data needed to support SOEC design } \\
\text { and model SOEC performance. }\end{array}$ & $\begin{array}{l}\text { Section 2, 3, and 4, Test plan for } \\
\text { HTSE cells. INL/EXT-10-19125 } \\
\text { addresses cell properties and } \\
\text { degradation issues. }\end{array}$ \\
\hline N.45.01.02 & GA & $\begin{array}{l}\text { SOEC Design and Performance. Lifetime testing } \\
(50,000 \text { hours }) \text { of individual cells. Hydrogen } \\
\text { production rate as a function of time and } \\
\text { temperature. }\end{array}$ & $\begin{array}{l}\text { Section } 2,3 \text {, and } 4 \text { Test plan for } \\
\text { HTSE cells. INL/EXT-10-19125 } \\
\text { addresses cell properties and } \\
\text { degradation issues }>10,000 \text { hours. }\end{array}$ \\
\hline N.45.02.01 & GA & $\begin{array}{l}\text { SOEC Unit Design and Performance. Lifetime } \\
\text { testing of individual }\left(1 \mathrm{Nm}^{3} / \text { hour }\right) \text { units. } \\
\text { Hydrogen production rate as a function of time } \\
\text { and temperature. }\end{array}$ & $\begin{array}{l}\text { Section 2, Test plan for HTSE } \\
\text { cells (C5). INL/EXT-10-19125 } \\
\text { addresses lab scale cell properties } \\
\text { and degradation issues. }\end{array}$ \\
\hline N.45.02.02 & GA & $\begin{array}{l}\text { SOEC Multiunit Integration and Performance. } \\
\text { Performance of multiple }(\sim 10) \text { integrated units. } \\
\text { Evaluation of manifolding configurations and } \\
\text { flow rates. Evaluation of electrical } \\
\text { configurations. }\end{array}$ & $\begin{array}{l}\text { Section 2, Test plan for HTSE } \\
\text { cells (C5). INL/EXT-10-19125 } \\
\text { addresses lab-scale cell properties } \\
\text { and degradation issues. }\end{array}$ \\
\hline N.45.03.01 & GA & $\begin{array}{l}\text { SOEC Pilot-Scale Module Demonstration. } \\
\text { Long-term performance of an engineering-scale } \\
\text { module }\left(600 \mathrm{Nm}^{3} / \text { hour }\right) \text { at high pressure. } \\
\text { Procedures for startup, control, and maintenance. } \\
\text { Assessment of instrumentation. Data for flow- } \\
\text { sheet assessment and validation, including steam } \\
\text { generation and hydrogen recycle. }\end{array}$ & $\begin{array}{l}\text { Section 3, Test plan for HTSE } \\
\text { cells (C6). INL/EXT-10-19125 } \\
\text { addresses pilot-scale cell } \\
\text { properties and degradation issues. }\end{array}$ \\
\hline N.45.03.03 & GA & $\begin{array}{l}\text { NGNP Solid Oxide Electrolysis Multimodule } \\
\text { Demonstration. Long-term performance of an } \\
\text { integrated high temperature electrolysis plant } \\
\text { consisting of } 10 \text { engineering-scale modules ( } 600 \\
\mathrm{Nm}^{3} / \text { hour) at high pressure. Procedures for } \\
\text { startup, control, and maintenance of multiple } \\
\text { modules. Assessment of instrumentation. Data } \\
\text { for flow-sheet assessment. }\end{array}$ & $\begin{array}{l}\text { Section } 4, \text { Test plan for HTSE } \\
\text { cells (C7). INL/EXT-10-19125 } \\
\text { addresses prototypic commercial } \\
\text { modules cell properties and } \\
\text { degradation issues }>10,000 \mathrm{hrs} \text {. }\end{array}$ \\
\hline HPS-01-02 & WEC & Gather Reaction Kinetics Data. & $\begin{array}{l}\text { Section 4.2.3, PLN-3604, } \\
\text { "Atomistic Modeling" identifies } \\
\text { preliminary results for } \\
\text { thermodynamic and kinetic } \\
\text { modeling. }\end{array}$ \\
\hline
\end{tabular}


Table 19. (continued).

\begin{tabular}{|c|c|c|c|}
\hline Number & Vendor & Description & Status \\
\hline HPS-01-03 & WEC & Analyze Data and Improve Simulation. & $\begin{array}{l}\text { Section 4.2.2, PLN-3604, } \\
\text { Computational Fluid Dynamics } \\
\text { (CFD) Modeling and Simulation, } \\
\text { Commercial CFD code FLUENT } \\
\text { was selected for detailed SOEC } \\
\text { modeling. }\end{array}$ \\
\hline HPS-04-07 & WEC & Provide Data Supporting Code Case. & $\begin{array}{l}\text { Pressure vessel code } \\
\text { demonstration for the modules } \\
\text { containing the stack arrays will } \\
\text { be developed as part of the } \\
\text { 'HTSE Pressure Boundary } \\
\text { System'. }\end{array}$ \\
\hline HPS-07-02 & WEC & Develop a Cell Membrane. & $\begin{array}{l}\text { Developed as part of 'HTSE } \\
\text { Cells'. }\end{array}$ \\
\hline $\begin{array}{l}\text { HPS-07-03 } \\
\text { HPS-ELE-03 }\end{array}$ & WEC & Develop a Cell Configuration and Materials. & $\begin{array}{l}\text { Section } 2,3 \text {, and } 4 \text {. Test plan for } \\
\text { HTSE cells. INL/EXT-10-19125 } \\
\text { addresses cell configuration tests } \\
\text { and materials. }\end{array}$ \\
\hline $\begin{array}{l}\text { HPS-07-04 } \\
\text { HPS-ELE-04 }\end{array}$ & WEC & Build and Test a Prototype Cell. & $\begin{array}{l}\text { Section 4, Test plan for HTSE } \\
\text { cells (C7). INL/EXT-10-19125 } \\
\text { addresses Prototype scale cell } \\
\text { properties and degradation issues. }\end{array}$ \\
\hline $\begin{array}{l}\text { HPS-07-05 } \\
\text { HPS-ELE-05 }\end{array}$ & WEC & Build and Test a Pilot-scale Cell. & $\begin{array}{l}\text { Section 3, Test plan for HTSE } \\
\text { cells (C6). INL/EXT-10-19125 } \\
\text { addresses Pilot scale cell } \\
\text { properties and degradation issues. }\end{array}$ \\
\hline $\begin{array}{l}\text { HPS-07-06 } \\
\text { HPS-ELE-06 }\end{array}$ & WEC & Build and Test a Stack of Cells in a Pilot Plant. & $\begin{array}{l}\text { Section 3, Test plan for HTSE } \\
\text { cells (C6). INL/EXT-10-19125 } \\
\text { addresses Pilot scale cell } \\
\text { properties and degradation issues. }\end{array}$ \\
\hline $\begin{array}{l}\text { HPS-08-01 } \\
\text { HPS-PPU-01 } \\
\text { HPS-FUS-01 }\end{array}$ & WEC & Identify Product Impurities. & $\begin{array}{l}\text { Impurities in the Hydrogen } \\
\text { product will be identified as a } \\
\text { part of 'HTSE Hydrogen Recycle } \\
\text { System'. }\end{array}$ \\
\hline $\begin{array}{l}\text { HPS-08-02 } \\
\text { HPS-PPU-02 }\end{array}$ & WEC & Test Product Purification Methods. & $\begin{array}{l}\text { Impurities in the Hydrogen } \\
\text { product will be identified as a } \\
\text { part of 'HTSE Hydrogen Recycle } \\
\text { System'.. }\end{array}$ \\
\hline $\begin{array}{l}\text { HPS-09-01 } \\
\text { HPS-PPU-DT-27 }\end{array}$ & WEC & Test Sensors in the Pilot Plant. & $\begin{array}{l}\text { Development of a pilot-scale test } \\
\text { facility at the } 200 \mathrm{~kW} \text { scale is } \\
\text { planned for the } 2015 \text { time frame } \\
\text { with design activities beginning } \\
\text { in FY } 2013 \text {. }\end{array}$ \\
\hline $\begin{array}{l}\text { HPS-ELE-07 } \\
\text { HPS-ELE-12 }\end{array}$ & WEC & $\begin{array}{l}\text { Test Alloys } 230 \text { and } 617 \text { in High Temperature } \\
\text { Helium and Air/Oxygen and Steam/Hydrogen } \\
\text { Mixtures. }\end{array}$ & $\begin{array}{l}\text { Materials testing for the } \\
\text { Hydrogen product will be } \\
\text { identified as a part of 'HTSE } \\
\text { Hydrogen Recycle System'. } \\
\text { Material testing for the Oxygen } \\
\text { product will be identified as part } \\
\text { of 'HTSE Sweep-gas and Oxygen } \\
\text { Handling System'. }\end{array}$ \\
\hline
\end{tabular}


Table 19. (continued).

\begin{tabular}{|c|c|c|c|}
\hline Number & Vendor & Description & Status \\
\hline HPS-ELE-09 & WEC & Provide Data Supporting a Code Case. & $\begin{array}{l}\text { Pressure vessel code } \\
\text { demonstration for the modules } \\
\text { containing the stack arrays will } \\
\text { be developed as part of the } \\
\text { 'HTSE Pressure Boundary } \\
\text { System'. }\end{array}$ \\
\hline HPS-ELE-10 & WEC & Develop Gasket Materials and Design. & $\begin{array}{l}\text { Pressure management methods } \\
\text { (seals, gaskets, joints, pressure } \\
\text { relief valves, etc.) will be } \\
\text { developed as a part of 'HTSE } \\
\text { Pressure Boundary System'. }\end{array}$ \\
\hline HPS-ELE-11 & WEC & Develop Seal Materials and Design. & $\begin{array}{l}\text { Pressure management methods } \\
\text { (seals, gaskets, joints, pressure } \\
\text { relief valves, etc.) will be } \\
\text { developed as a part of 'HTSE } \\
\text { Pressure Boundary System'. }\end{array}$ \\
\hline HPS-ELE-DT-03 & WEC & $\begin{array}{l}\text { Design a cell stack suitable for operation at high } \\
\text { temperature in a high pressure, oxygen-rich } \\
\text { environment. }\end{array}$ & $\begin{array}{l}\text { Section } 2,3 \text {, and } 4 \text {, Test plan for } \\
\text { HTSE cells. INL/EXT-10-19125 } \\
\text { addresses cell properties and } \\
\text { degradation issues. }\end{array}$ \\
\hline HPS-ELE-DT-04 & WEC & $\begin{array}{l}\text { Design an economical stack enclosure that } \\
\text { minimizes heat loss, sealing and stack handling } \\
\text { and maximizes safety. }\end{array}$ & $\begin{array}{l}\text { R\&D for heat management } \\
\text { methods (insulation, cooling, } \\
\text { expansion, etc.) will be } \\
\text { developed as a part of 'HTSE } \\
\text { Pressure Boundary System'. Both } \\
\text { Pilot-scale and Engineering-scale } \\
\text { designs are included in the March } \\
2011 \text { 'NGNP HTSE Technical } \\
\text { Program Plan'. }\end{array}$ \\
\hline HPS-ELE-DT-05 & WEC & $\begin{array}{l}\text { Design a conceptual plant layout and piping } \\
\text { arrangement that accommodates expected } \\
\text { thermal expansion. }\end{array}$ & $\begin{array}{l}\text { Both Pilot-scale and Engineering- } \\
\text { scale designs are included in the } \\
\text { March } 2011 \text { 'NGNP HTSE } \\
\text { Technical Program Plan'. }\end{array}$ \\
\hline HPS-FUS-02 & WEC & Develop Feedwater Purification Methods. & $\begin{array}{l}\text { Water purification will be an } \\
\text { engineering demonstration of } \\
\text { existing technology rather than } \\
\text { R\&D. }\end{array}$ \\
\hline HPS-FUS-03 & WEC & Develop Process Fluid Purification Methods. & $\begin{array}{l}\text { Process fluid purification will be } \\
\text { developed as a part of 'HTSE } \\
\text { Hydrogen Recycle System'. } \\
\text { Materials testing for the Oxygen } \\
\text { product will be identified as part } \\
\text { of the 'HTSE Sweep-gas and } \\
\text { Oxygen Handling System'. }\end{array}$ \\
\hline $\begin{array}{l}\text { HPS-FUS-DT-01 } \\
\text { HPS-FUS-DT-09 }\end{array}$ & WEC & $\begin{array}{l}\text { Design a feedwater purification system that } \\
\text { includes equipment sizing and economics. }\end{array}$ & $\begin{array}{l}\text { Water purification will be an } \\
\text { engineering demonstration of } \\
\text { existing technology rather than } \\
\text { R\&D. }\end{array}$ \\
\hline $\begin{array}{l}\text { HPS-FUS-DT-02 } \\
\text { HPS-FUS-DT-10 }\end{array}$ & WEC & $\begin{array}{l}\text { Design a process fluid purification system that } \\
\text { includes equipment sizing and economics. }\end{array}$ & $\begin{array}{l}\text { Both Pilot-scale and Engineering- } \\
\text { scale designs are included in the } \\
\text { March } 2011 \text { 'NGNP HTSE } \\
\text { Technical Program Plan'. }\end{array}$ \\
\hline
\end{tabular}


Table 19. (continued).

\begin{tabular}{|c|c|c|c|}
\hline Number & Vendor & Description & Status \\
\hline HPS-PCN-01 & WEC & Test Sensors in the Pilot Plant. & $\begin{array}{l}\text { Development of a pilot-scale test } \\
\text { facility at the } 200 \mathrm{~kW} \text { scale is } \\
\text { planned for the } 2015 \text { time frame } \\
\text { with design activities beginning } \\
\text { in FY } 2013 \text {. }\end{array}$ \\
\hline HPS-PCN-03 & WEC & Test Valves in the Pilot Plant. & $\begin{array}{l}\text { Development of a pilot-scale test } \\
\text { facility at the } 200 \mathrm{~kW} \text { scale is } \\
\text { planned for the } 2015 \text { time frame } \\
\text { with design activities beginning } \\
\text { in FY } 2013 \text {. }\end{array}$ \\
\hline HPS-PCN-DT-12 & WEC & $\begin{array}{l}\text { Identify appropriate valve materials and sensing } \\
\text { devices for the aggressive environments of the } \\
\text { process technology. }\end{array}$ & $\begin{array}{l}\text { Materials testing for the } \\
\text { Hydrogen product will be } \\
\text { identified as a part of 'HTSE } \\
\text { Hydrogen Recycle System'. } \\
\text { Material testing for the Oxygen } \\
\text { product will be identified as part } \\
\text { of 'HTSE Sweep-gas and Oxygen } \\
\text { Handling System'. Sensing } \\
\text { devices will be developed as part } \\
\text { of 'HTSE Instrumentation and } \\
\text { Control System'. }\end{array}$ \\
\hline
\end{tabular}

\subsubsection{Additional Technological Development}

This section identifies some proposed programs, but there is no specific test plan identified for this work. There is no schedule identified for these activities.

\section{Integrated Laboratory Scale}

Performance degradation with the ILS system was observed over a period of 700 hours of test time. Despite this cell degradation, the ILS was able to successfully demonstrate large-scale hydrogen production $(5,000 \mathrm{~L} /$ hour $)$ with heat recuperation and hydrogen recycle, as would be required in a largescale plant. A follow-on laboratory-scale demonstration is anticipated in the FY 2012 time frame. The selection of the cell and stack technology to be used for this test will be based on bench-scale testing that has demonstrated excellent initial performance and very low long-term degradation rate.

\section{System Modeling}

The HTSE program will have an ongoing need for system modeling activities. One anticipated need will be to examine the potential performance of HTSE coupled to various small modular reactor concepts. System modeling will also be needed to design larger-scale test facilities such as the HTSE pilot plant planned for operation at INL in the 2014 to 2016 time frame.

\section{Degradation Testing}

Degradation testing and analysis will be performed during FY 2011 at both INL and subcontractor locations. Subcontractor testing will be performed at Versa Power and University of Connecticut. Test articles for in-house testing at INL will be supplied by St. Gobain, and possibly Topsoe.

\section{Cell Development}

Advanced cell and stack development activities will be supported at Ceramatec, MSRI, and National Aeronautics and Space Administration for FY 2011. Cell development will focus on improving 
performance in the electrolysis mode, addressing degradation mechanisms such as delamination of air electrodes observed primarily in the electrolysis mode. Ceramatec is developing an advanced airelectrode-supported cell.

\subsubsection{Risk Analysis and PIRTs}

There are no PIRTS associated with the HTSE system.

\subsubsection{Technology Development Roadmap}

A TDRM for NGNP R\&D HTSE is shown in Appendix A.

\subsubsection{Section Summary}

All of the HTSE DDNs are addressed within the HTSE program. There does however need to be more detail added to the seven key R\&D activities in the HTSE program plan to identify specific R\&D activities that meet the DDN requirements.

There are no PIRTS associated with the HTSE system.

\subsection{Methods}

NGNP Methods R\&D focuses on the development and validation of tools to assess the neutronic and thermal fluid behavior of the plant.

\section{Functions Performed}

The methods content for this document are taken from PLN-2498, "NGNP Methods Technical Program Plan", Revision. 2, INL, September 27, 2010. The experimental needs and required R\&D are focused in six distinct areas based on the relative state of the software in each:

- Basic cross-section data measurement and evaluation

- Lattice calculations of cross sections for core burnup and dynamic analysis

- Reactor core simulation (core flux, power, temperature, coolant flow and burnup profiles)

- Reactor kinetics (special changes in flux power, temperature as a function of time)

- Fuel and material behavior (neutronic and thermal fluid behavior)

- Fission product transport (fission product movement once escaped from confines of fuel).

HTGRs employ passive design features that prevent both plant damage and significant releases of radioactive materials, even under extreme circumstances. Yet the operating experience with these reactors is limited, and the most challenging scenarios have not been experienced. Furthermore, while the overall safety margin can be quite large, local variations in temperature can challenge the integrity of structural materials and reduce the life of components. The legacy codes and models used to simulate the behavior of HTGR plants rely on assumptions and approximations that lead to considerable uncertainty in important figures-of-merit. Modern high-resolution codes have yet to be qualified for HTGR applications. The NGNP Methods task is devoted to developing high fidelity, accurate simulations of plant phenomena and generating the experimental data needed to validate codes and models to the satisfaction of the designer, regulator, and end user. Project risk is reduced through the simulation of scenarios and phenomena with high confidence in the results and limited uncertainties. 
The role of the NGNP Methods program is to provide an independent and accessible validation, verification, and high fidelity simulation capability against which all NGNP stakeholders can benchmark their tools.

\subsubsection{Research and Development Test Plans for Methods}

R\&D of NGNP Methods development programs are being planned and executed in conformance with the approach, practices, and methodologies recommended in NRC Regulatory Guide 1.203 - 'Transient and Accident Analysis Methods'.

The current Methods technical program identifies activities extending to 2016. The highest-priority Methods activities for FY 2011 through 2013 will include: conducting integral experiments in the High Temperature Test Facility (HTTF), completing and operating the Natural Circulation Shutdown Test Facility for investigation of ex-core heat removal, performing bypass and air ingress experiments with associated computational fluid dynamics (CFD) model validation, and completing the development of 3D core simulation tools for analyzing complex core behavior under anticipated normal and off-normal conditions, including a range of loss-of-forced-cooling events.

\subsubsection{Research and Development Tasks}

This section identifies the R\&D Methods activities to be performed in order for the program to meet its key goals, which are to:

1. Define the calculational envelope required to be able to analyze the candidate HTGR reactor systems.

2. Design and execute a matrix of experiments that will produce a comprehensive data set that can be used to validate and verify NGNP evaluation models developed by DOE, NRC, and vendors.

3. Develop uncertainty and sensitivity analysis capability that can be used to identify and prioritize gaps in the ability of an evaluation model to compute safety and performance parameters within confidence intervals.

\subsubsection{Experimental Validation of CFD and System Codes}

\section{Bypass Flow}

Bypass flow is a series of experiments that will test theories regarding factors that affect the quantity of bypass flow for both prismatic and PBRs. Some influencing factors would be manufacturing tolerances and core configuration changes from irradiation or thermal expansion. It is thought that the work scope will be a DOE laboratory-university partnership.

\section{Air Ingress and Graphite Oxidation}

A number of isothermal air ingress experiments are presently under way. Heated air ingress experiments will be performed using the HTTF. Graphite oxidation experiments are being performed as part of the NGNP Graphite Characterization program. The data from these experiments will be used in multiphysics air ingress simulations using the 'GAMMA' code.

Water ingress was not identified in the original PIRT to be a high frequency scenario, but the shift to water as a secondary loop working fluid poses a substantially higher risk of water ingress. Reference reactor design includes a high-pressure, water-filled secondary system. From the PIRT results, a set of experiments will be designed that are scaled to represent the reference design and new points will be inserted in the thermal-fluids validation matrix. 


\section{Core Heat Transfer and Plenum-to-Plenum}

The characteristics of the hottest cooling channels at operational conditions are considered a key calculational result, since the hot channel temperature distribution defines the hottest initial condition for the fuel and surrounding materials.

The distribution of the flow between the various coolant channels in a prismatic HTGR reactor is important in determining the warmest part. Experiments are needed to investigate core heat transfer. The experiments will support the efforts of the current computational task concerning the hot channel issue by providing benchmark data for detailed assessment of its turbulence models for forced and mixed convection with helium property variation.

A matched-index-of-refraction experiment is planned to examine flows near outlets in PBRs. A key difficulty in analyzing the safety of PBR systems is predicting the maximum fuel temperatures and chemical reaction rates locally in the coolant outlet region (e.g., hot spots) where the temperature field is generally high. Measurements are needed to examine the validity of any models employed and their related constitutive theories. The INL matched-index-of-refraction flow system is ideal to investigate these difficulties in detail.

\section{Upper and Lower Plenum}

The mixing of hot plumes in the upper plenum of a gas-cooled reactor is of concern during a pressurized cooldown. An experiment is planned to investigate interactions between hot plumes and parallel flow instabilities. The experiment will produce a scaled fluid behavior simulation of plumes moving upwards from the hot core cooling channels of the natural circulation development in the upper plenum and of the downward movement of upper plenum inventory into the cooler channels in route to the lower plenum. Sufficient instrumentation will be used to characterize the flow behavior for CFD validation data sets.

\section{Ex-Core Heat Transfer}

Convective cooling contribution is an important ingredient in describing the total heat transfer from the core, and thus the ultimate peak core and vessel temperatures, these heat transfer phenomena are potentially important. The objective of this task is therefore to acquire the model/code validation data for natural convection and radiation heat transfer in the reactor cavity and the RCCS by performing experiments in the Argonne National Laboratory (ANL) Natural Convection Shutdown Heat Removal Test Facility (NSTF).

\section{Fission Product and Dust Transport}

The AGR Fuel Qualification Program addresses the generation and transport of fission products out of the fuel and block matrix. The transport of fission products out of the primary system and into the reactor building will be addressed in Methods. During events involving primary coolant leakage into the silo and onto the building, natural processes will act to reduce the level of entrained radionuclides as the gas stream transits. Data are needed to develop and validate the methods describing the behavior of condensable radionuclides in the building under wet and dry conditions for these accidents.

\section{Reactor Physics}

Integral benchmark experiment data for existing critical configurations that are neutronically similar to contemplated NGNP designs are required for physics code validation and QA, both as part of the reactor design process and for licensing applications. Mathematically rigorous sensitivity studies for representative HTGR core designs are required as an aid in guiding the design of any needed critical experiments that cannot be replaced by simulations and for quantification of the propagation of 
uncertainties in computational simulations because of uncertainties in the underlying nuclear data and other parameters that make up the input to the simulation models.

\section{Engineering Scale Reactors}

Two gas-cooled test reactors are presently operational for integral experiments: the Chinese High Temperature Gas-cooled Reactor (HTR-10) located at the Institute of Nuclear Energy Technology in Beijing, China, and the High Temperature Engineering Test Reactor (HTTR) at the Japan Atomic Energy Agency (JAEA) in Oarai, Japan. Since integral experiments are the only experimental sources that may be able to produce the complex interactions between dominant phenomena identified in the NGNP systemspecific PIRT, they are essential for systems analysis and CFD code validation studies. Data from both the HTTR and the HTR-10 will be important in the calculational matrix required for plant licensing by NRC.

Based on the MHTGR, the HTTF is being designed and will be constructed at a facility at Oregon State University in Corvallis, OR. The HTTF is scaled to one quarter of the size of the MHTGR and will have an electrically-heated core . The first HTTF configuration is prismatic; however subsequent HTTF configurations may also be pebble-bed, depending on the need.

The HTTF will be operational for startup testing in FY 2012 and the formal prismatic test program will begin in FY 2013. It is anticipated that the HTTF will generate data for several years and the experimental test matrix will be tailored to match the experiments scheduled for inclusion in all of the other experimental facilities, including the RCCS, plenum experiments, core heat transfer experiments, air ingress experiments, and bypass flow experiments.

\subsubsection{Core and Plant Simulation}

The NGNP will rely heavily upon simulations to ascertain plant behavior under all anticipated circumstances. The main objectives of the NGNP Core Simulation task are to develop high fidelity models and benchmarks for investigating challenging HTGR phenomena and scenarios, and to increase confidence in, or at least quantify the uncertainties in vendor calculations and NRC evaluations models.

\section{Prismatic Reactor Core Simulation}

Under NGNP, INL has developed a modification to the analytical Nodal Green's Function Method (NGFM) for nodal diffusion codes that explicitly treat local absorption in the nodal balance equation. The new method is being implemented in the HEXPEDITE code. The NGFM solver in HEXPEDITE retains the accuracy of DIF3D-VARIANT and the speed of DIF3D-nodal. Coarse mesh nodal solvers, such as HEXPEDITE, relieve the computational burden by solving the diffusion equation in a higher fidelity form, but over a much coarser mesh.

For steady-state and depletion problems in core analysis, the INL has developed the INSTANT multigroup transport code. INSTANT solves the neutral particle transport code using either the spherical harmonic or discrete ordinate approximation to the Boltzmann transport equation. Originally developed as a general purpose reactor physics tool under NGNP, INSTANT will be coupled to a depletion code (MRTAU) and to the INL plant analysis code RELAP5-3D. This code system will provide accurate flux, power, and burnup profiles at specified points in the prismatic fuel cycle and will provide the initial conditions for subsequent transient analysis.

\section{PBR Core Simulation}

INL has developed the PEBBED code for steady-state and depletion problems (core design and fuel management) in PBR simulation. PEBBED solves the multigroup diffusion and burnup equations for recirculating pebble bed cores in which the fuel is continuously loaded and moving downward through 
the core during operation. Under NGNP, the COMBINE code has been modified to generate accurate cross sections for PEBBED analysis. The accurate computation of burnup in the pebble bed requires knowledge of the direction and speed of the pebble flow. INL has developed the PEBBLES code, which simulates the mechanics of flowing pebbles. This code system will provide accurate flux, power, and burnup profiles at specified points in the pebble bed fuel cycle and will provide the initial conditions for subsequent transient analysis.

\section{Core Thermal Fluids}

Core and system thermal simulation of both the pebble bed and prismatic HTGRs can be performed accurately to first order with low order fluid dynamics and heat transfer equations that assume either a uniform porous medium (pebble bed) or a network of individual pipes (coolant channels in prismatic reactors) with a common pressure drop (the density is also assumed to be constant). These codes rely on experimentally determined friction factor and heat transfer correlations appropriate to the geometry and materials used. For the PBR, the THERMIX-KONVEK code is being upgraded to 3-D and tighter coupling to the PEBBED fuel management system. For the prismatic reactor, appropriate 1-D fluid flow correlations will be testing in the RELAP5-3D code to provide corewide thermal fluid profiles for fuel management problems.

\section{Plant Simulation and Process Heat Plant Coupling}

The Methods program will be using RELAP5-3D for system-wide analysis of NGNP. The core model can be coupled to various balance-of-plant (BOP) components to investigate system-level interactions and behavior, and to support economic analysis of process heat plant applications. The commercial software packages ASPEN and HYSIS have been acquired by the Project and used to simulate the behavior of candidate process heat and hydrogen production plants. RELAP5 models of the primary loop (core, SG, and IHX may be coupled to ASPEN or use the output data as boundary conditions. As the IHX and SGs will be most sensitive to core and load transients, the effective coupling of RELAP and ASPEN will be an important challenge for assessing performance.

\section{Multi-physics Applications}

For some problems, the relatively coarse and approximate thermal fluid modeling capability of RELAP5-3D is insufficient. Detailed and complex thermal fluid phenomena require a high resolution multiphysics capability developed and operated on a high performance computing platform. The approach being pursued under NGNP is to build a core simulator with MOOSE - a computational platform specifically designed for solving arbitrary and complex systems of partial differential equations. Because the basic meshing and solver tools are embedded within MOOSE, the code developer need only provide the governing equations that describe the physics of the system.

Time-dependent neutron diffusion and advanced porous medium and 3-D fluid solvers are being implemented into the MOOSE framework, specifically, to solve challenging transient problems in both pebble bed and prismatic core behavior. The MOOSE framework allows the application code (PRONGHORN) to be expanded to include such phenomena as graphite oxidation, fuel particle stress analysis, and graphite deformation with full feedback.

The PRONGHORN application necessarily employs lower order neutronics and thermal fluid equation systems in order to support computational intensive transient analyses, albeit with very high resolution in the time and spatial domains. High order coupled neutron transport and CFD offer an exact description of the system in question that can be executed in reasonable times for steady state problems. The SHARP code system developed at ANL will provide such high fidelity snapshots against which the lower order methods can be compared. The SHARP-VHTR code system has been tested on a one twelfth 
scale core model of the Gas Turbine-Modular Helium Reactor (GT-MHR) and will be used to provide benchmark-quality results for verifying the other codes in the DOE evaluation model.

\section{Fuel Performance and Core Dynamics}

INL has developed the PASTA (Particle Stress Analysis) code for computing the mechanical stress on the TRISO boundaries as a function of temperature, gas pressure, and other factors.

\section{Uncertainty and Sensitivity Analysis}

Quantification of the uncertainties in computed core physics parameters that result from propagation of uncertainties in the underlying nuclear data and other input parameters used in the various modeling codes is a key component of the quality assurance process for reactor physics modeling and simulation.

Variational theory cannot yet be applied to the coupled core simulation problem, causing reliance on forward sensitivity techniques. In this approach input parameters are manipulated in a stochastic manner over their known and estimated range of variability.

A very limited number of computer codes are available for performing such analyses, one of which is the Software for Sensitivity and Uncertainty Analysis (conduction cooldown) code developed by the GRS (Gesellschaft für Anlagen und Reaktorsicherheit) company of Germany. conduction cooldown envelopes the user's analysis code, manipulates the user-supplied input parameters over the specified ranges, executes the minimum number of runs to generate a certain confidence value in the output uncertainty, and computes and ranks the output sensitivities. This software has been acquired by the Project and is being evaluated. Applications to core simulation will commence in FY 2011.

\subsubsection{Methods Status}

The current status of methods available for designing and analyzing the NGNP HTGR can be summarized as follows:

- Software and advanced detailed methods are not ready to perform design and licensing analyses to the standard required for NGNP. Development of the DOE Evaluation Model is about $65 \%$ complete, meaning that the codes are capable of simulating most HTGR phenomena of interest but need to be verified and validated against experimental data before being put into production.

- The practices and procedures acceptable for validating and developing the software tools for the HTGR must be defined and implemented to a standard defined by the engineering community.

The risks involved with complex engineering projects can be reduced with modeling efforts that can resolve key performance and safety issues early in the design process

\subsubsection{Design Data Needs}

Several DDNs are associated with the technological development of the NGNP Methods. Document references in Table 19 are from PLN-2498, "Next Generation Nuclear Plant Methods Technical Program Plan (Rev. 2, September, 27, 2010). The first three column references are from DDN documents (see 'References' section, numbers 15, 16 and 17).

Table 20. Methods DDNs.

\begin{tabular}{|ccll|}
\hline Number & Vendor & \multicolumn{1}{c|}{ Description } & \multicolumn{1}{c|}{ Status } \\
\hline 4.1.1.1 & AREVA & $\begin{array}{l}\text { CABERNET model enhancement to } \\
\text { include short-term transient analysis } \\
\text { capability to reactivity events for block } \\
\text { type cores. }\end{array}$ & $\begin{array}{l}\text { There are no model enhancements to } \\
\text { CABERNET identified in the INL Methods } \\
\text { program. This is a vendor specific activity. }\end{array}$ \\
\hline
\end{tabular}


Table 20. (continued).

\begin{tabular}{|c|c|c|c|}
\hline Number & Vendor & Description & Status \\
\hline 4.1.1.2 & AREVA & $\begin{array}{l}\text { Cross-section data is needed as input } \\
\text { into NEPHTIS. Originally this DDN was } \\
\text { written with a } 950^{\circ} \mathrm{C} \text { reactor in mind. } \\
\text { Give the lower temperature of the NGNP } \\
\text { now, existing cross-sections may be } \\
\text { adequate. }\end{array}$ & $\begin{array}{l}\text { Cross sectional data will be gathered from } \\
\text { facilities such as HTTF and NSTF. }\end{array}$ \\
\hline 4.1.2.2 & AREVA & $\begin{array}{l}\text { Thermal Hydraulics. STAR-CD } \\
\text { Graphite Oxidation Model Development } \\
\text { for Water and Air Ingress. }\end{array}$ & $\begin{array}{l}\text { Section 4.1.2.2 Air Ingress and Graphite } \\
\text { Oxidation identifies R\&D for a number of } \\
\text { scenarios related to water and air ingress. Air } \\
\text { ingress experiments will be performed at } \\
\text { HTTF from } 2012 \text { for at least } 1 \text { year. }\end{array}$ \\
\hline 4.1.3.1a & AREVA & $\begin{array}{l}\text { Refinement of ATLAS models is needed } \\
\text { for better prediction of how fission } \\
\text { products interact with coatings. }\end{array}$ & $\begin{array}{l}\text { There are no refinements of ATLAS } \\
\text { identified in the INL Methods program (this is } \\
\text { a vendor specific activity). The AGR fuel } \\
\text { qualification program addresses the } \\
\text { generation and transport of fission products } \\
\text { out of the fuel and block matrix. Vendor } \\
\text { specific activity. }\end{array}$ \\
\hline $4.1 .3 .1 \mathrm{~b}$ & AREVA & $\begin{array}{l}\text { Fuel hydrolysis modeling needs to be } \\
\text { included in ATLAS for fuel performance } \\
\text { prediction during water ingress events. }\end{array}$ & $\begin{array}{l}\text { There are no refinements of ATLAS } \\
\text { identified in the INL Methods program (this is } \\
\text { a vendor specific activity). The AGR fuel } \\
\text { qualification program addresses fuel } \\
\text { hydrolysis modeling during water ingress } \\
\text { events. Vendor specific activity. }\end{array}$ \\
\hline 4.1.3.1c & AREVA & $\begin{array}{l}\text { Checking and possibly adapting the } \\
\text { coated particle and compact irradiation } \\
\text { models in ATLAS versus data from the } \\
\text { AGR irradiation program will help } \\
\text { assess NGNP fuel performance. } \\
\text { Calculation of the failure fraction and } \\
\text { fission product release rate from a fuel. }\end{array}$ & $\begin{array}{l}\text { Vendor specific activity. The AGR fuel } \\
\text { qualification program addresses fission } \\
\text { product release rate from fuel. }\end{array}$ \\
\hline 4.1.3.1d & AREVA & $\begin{array}{l}\text { ATLAS heat-up modeling predictions } \\
\text { have to be compared with experimental } \\
\text { heat-up data, and might have to be } \\
\text { improved following such comparison. }\end{array}$ & Vendor specific activity. \\
\hline $4.1 .3 .1 \mathrm{e}$ & AREVA & $\begin{array}{l}\text { The ATLAS code currently has no UCO } \\
\text { models, so these models need to be } \\
\text { developed. }\end{array}$ & Vendor specific activity. \\
\hline 4.1.4.1a & AREVA & $\begin{array}{l}\text { Fission product Transport. Development } \\
\text { of Model for Activation Product } \\
\text { Assessment in the Primary Circuit. }\end{array}$ & $\begin{array}{l}\text { The AGR Fuel Qualification Program } \\
\text { addresses the generation and transport of } \\
\text { fission products out of the fuel and block } \\
\text { matrix into the primary circuit. }\end{array}$ \\
\hline $4.1 .4 .1 \mathrm{~b}$ & AREVA & $\begin{array}{l}\text { Fission product Transport. Modeling of } \\
\text { Tritium Migration and Control in SG } \\
\text { and Secondary Water Loops. }\end{array}$ & $\begin{array}{l}\text { Tritium permeation measurements have been } \\
\text { taken and were acquired by the Project in } \\
2010 \text { (from the HTTR in Oarai, Japan). This } \\
\text { data will be used to validate the Tritium } \\
\text { Permeation Analysis Code recently developed } \\
\text { at the INL to study tritium permeation in } \\
\text { HTGRs. }\end{array}$ \\
\hline
\end{tabular}


Table 20. (continued).

\begin{tabular}{|c|c|c|c|}
\hline Number & Vendor & Description & Status \\
\hline $4.1 .4 .1 \mathrm{c}$ & AREVA & $\begin{array}{l}\text { Fission product Transport. Modeling of } \\
\text { Radio-Contaminant Distribution in the } \\
\text { Primary Circuit. }\end{array}$ & $\begin{array}{l}\text { The AGR Fuel Qualification Program } \\
\text { addresses the generation and transport of } \\
\text { fission products out of the fuel and block } \\
\text { matrix into the primary circuit. }\end{array}$ \\
\hline $4.1 .4 .1 \mathrm{~d}$ & AREVA & $\begin{array}{l}\text { Fission product Transport. Modeling of } \\
\text { Radio-Contaminant Release outside the } \\
\text { Primary Pressure Boundary. }\end{array}$ & $\begin{array}{l}\text { The transport of fission products out of the } \\
\text { primary system and into the reactor building } \\
\text { will be addressed in Methods. Once the NSTF } \\
\text { is configured for the RCCS experiment, the } \\
\text { structures and geometry for the condensation } \\
\text { of the fission products will be available for an } \\
\text { integral large-scale experimental simulation } \\
\text { of fission product transport in this cavity and } \\
\text { silo. }\end{array}$ \\
\hline $4.1 .4 .1 \mathrm{e}$ & AREVA & $\begin{array}{l}\text { Fission product Transport. Modeling of } \\
\text { Radio-Contaminant Releases in the } \\
\text { Environment for Accidental Situations. }\end{array}$ & $\begin{array}{l}\text { A number of experiments are being proposed } \\
\text { (one of which is the Thermal-hydraulics, } \\
\text { Hydrogen, Aerosols, Iodine [THAI] facility), } \\
\text { but the primary deliverable of this series of } \\
\text { experiments would be fission product } \\
\text { retention factors (amount released from the } \\
\text { building/amount released from the core), } \\
\text { which could be incorporated directly into a } \\
\text { safety analysis or Probability Risk } \\
\text { Assessment. }\end{array}$ \\
\hline 4.1.4.1f & AREVA & $\begin{array}{l}\text { Fission product Transport. Development } \\
\text { of Fission Product Wash-off Modeling. }\end{array}$ & $\begin{array}{l}\text { No reference was found to fission product } \\
\text { wash-off modeling - an unresolved issue in } \\
\text { fission product transport. Transport of fission } \\
\text { products from the fuel matrix into the primary } \\
\text { coolant stream is captured under the AGR } \\
\text { Fuel Qualification Program. The transport of } \\
\text { Fission product around the primary coolant } \\
\text { stream and beyond is a joint Fuels/Methods } \\
\text { task. }\end{array}$ \\
\hline 4.1.4.1g & AREVA & $\begin{array}{l}\text { Fission product Transport. Data } \\
\text { Collection for Fission Product Aerosols. }\end{array}$ & $\begin{array}{l}\text { Data collection for Fission Product aerosols } \\
\text { and dust dispersion experiments can be } \\
\text { performed in Argonne's Zero Power Reactor } \\
\text { Cell } 5 .\end{array}$ \\
\hline 4.1.4.2a & AREVA & $\begin{array}{l}\text { Structural Analysis. Completion of } \\
\text { Experimental Databases for Structural } \\
\text { Mechanics Codes. }\end{array}$ & $\begin{array}{l}\text { Not currently in the Methods program, this is } \\
\text { because INL has not identified a need in this } \\
\text { area. The existing structural analysis methods } \\
\text { are largely adequate for the purpose. As } \\
\text { AREVA implies, however, the input data is } \\
\text { probably incomplete. This is a task for NGNP } \\
\text { Materials, not Methods }\end{array}$ \\
\hline 4.1.4.2b & AREVA & $\begin{array}{l}\text { Structural Analysis. Development of } \\
\text { Block-Type Core Dynamic Modeling. }\end{array}$ & $\begin{array}{l}\text { This activity is part of the long-term plan, an } \\
\text { evolution of bypass flow. }\end{array}$ \\
\hline $4.1 .4 .2 \mathrm{c}$ & AREVA & $\begin{array}{l}\text { Structural Analysis. Modeling of Fluid } \\
\text { Structure Interaction and Flow-Induced } \\
\text { Vibration. }\end{array}$ & $\begin{array}{l}\text { Not currently in the Methods program. } \\
\text { However the CFD work is a precursor to this } \\
\text { activity. Once a specific problem is defined in } \\
\text { this area, it can be included in the Methods or } \\
\text { Materials Plans. Flow-induced vibrations are } \\
\text { likely to be an issue only in BOP components, } \\
\text { not in the core itself. }\end{array}$ \\
\hline
\end{tabular}


Table 20. (continued).

\begin{tabular}{|c|c|c|c|}
\hline Number & Vendor & Description & Status \\
\hline $4.1 .4 .2 \mathrm{~d}$ & AREVA & $\begin{array}{l}\text { A methodology needs to be developed to } \\
\text { assess vessel behavior during normal } \\
\text { and accident conditions. The proposed } \\
\text { safety approach excludes the vessel } \\
\text { rupture and thus relies on a leak-before- } \\
\text { break approach that has not been } \\
\text { established for gas-cooled reactors. }\end{array}$ & $\begin{array}{l}\text { One of Methods overall program } \\
\text { requirements is to address safety and } \\
\text { performance issues identified in the NGNP } \\
\text { PIRT. To understand and model reactor } \\
\text { behavior in normal and off-normal scenarios. }\end{array}$ \\
\hline $4.2 .1 .1 \mathrm{c}$ & AREVA & $\begin{array}{l}\text { In-core measurements of power and } \\
\text { temperature distributions in NGNP are } \\
\text { needed to qualify coupled } \\
\text { neutronics/thermal-hydraulics } \\
\text { calculations in CABERNET, and } \\
\text { therefore, allow reaching nominal } \\
\text { power. }\end{array}$ & $\begin{array}{l}\text { HTTF and NSTF are facilities that will } \\
\text { generate data for basic neutronics modeling. } \\
\text { The use of CABERNET is vendor specific. }\end{array}$ \\
\hline 4.2.1.2 & AREVA & $\begin{array}{l}\text { A dedicated critical experiment with } \\
\text { representative configurations is needed } \\
\text { for qualifying MCNP for NGNP core } \\
\text { calculations with pin-by-pin power } \\
\text { distributions and control rod and } \\
\text { burnable poisons worths. }\end{array}$ & $\begin{array}{l}\text { No dedicated critical experiment was } \\
\text { identified for qualifying MCNP for NGNP } \\
\text { core calculations. While there are } \\
\text { uncertainties in the nuclear data libraries that } \\
\text { can be addressed with a dedicated critical } \\
\text { experiment, the reduction in risk is not } \\
\text { commensurate with the expense of such a } \\
\text { facility. Past critical experiments (graphite- } \\
\text { low enriched uranium) are sufficiently } \\
\text { representative of NGNP to provide some } \\
\text { validation of codes. The real uncertainties in } \\
\text { the nuclear data libraries are in minor } \\
\text { actinides at high burnup. }\end{array}$ \\
\hline 4.2.1.2 & AREVA & $\begin{array}{l}\text { Dedicated critical experiments, with an } \\
\text { asymptotic spectrum representative of } \\
\text { the expected prismatic fuel assembly and } \\
\text { core, with full access to pin-by-pin } \\
\text { power distributions and control rod and } \\
\text { burnable poisons worth are needed. }\end{array}$ & $\begin{array}{l}\text { New dedicated critical experiments are not } \\
\text { planned. The Methods program will be } \\
\text { relying on past critical experiments such as } \\
\text { Proteus, HTTR, and HTR-10. }\end{array}$ \\
\hline 4.2.1.3a & AREVA & $\begin{array}{l}\text { Neutronics. Results of Fuel Irradiation } \\
\text { Experiments for MONTEBURNS } \\
\text { Qualification. }\end{array}$ & $\begin{array}{l}\text { The AGR Fuel Qualification Program } \\
\text { addresses fuel irradiation data results. } \\
\text { Experiments for MONTEBURNS is a vendor } \\
\text { specific activity. }\end{array}$ \\
\hline $4.2 .1 .3 \mathrm{~b}$ & AREVA & $\begin{array}{l}\text { Neutronics. Experimental Results of } \\
\text { Decay Heat for MONTEBURNS } \\
\text { Qualification. }\end{array}$ & $\begin{array}{l}\text { The AGR Fuel Qualification Program } \\
\text { addresses decay heat data results. } \\
\text { Experiments for MONTEBURNS is a vendor } \\
\text { specific activity. }\end{array}$ \\
\hline 4.2.1.4 & AREVA & $\begin{array}{l}\text { A dedicated critical experiment with } \\
\text { representative configurations is needed } \\
\text { for qualifying NEPHTIS for NGNP core } \\
\text { calculations with pin-by-pin power } \\
\text { distributions and control rod and } \\
\text { burnable poisons worth. }\end{array}$ & $\begin{array}{l}\text { Dedicated critical facilities for the NGNP will } \\
\text { not be constructed; validation of neutronic } \\
\text { codes will rely on data from critical facilities } \\
\text { that operated in the past and on existing } \\
\text { HTGR engineering scale reactors (HTTR and } \\
\text { HTR-10). Qualifying NEPHTIS is a vendor } \\
\text { specific activity. }\end{array}$ \\
\hline
\end{tabular}


Table 20. (continued).

\begin{tabular}{|c|c|c|c|}
\hline Number & Vendor & Description & Status \\
\hline 4.2.1.5 & AREVA & $\begin{array}{l}\text { Neutronics. Results of Fuel Irradiation } \\
\text { Experiments for NEPHTIS } \\
\text { Qualification. }\end{array}$ & $\begin{array}{l}\text { Dedicated critical facilities for the NGNP will } \\
\text { not be constructed; validation of neutronic } \\
\text { codes will rely on data from critical facilities } \\
\text { that operated in the past and on existing } \\
\text { HTGR engineering scale reactors (HTTR and } \\
\text { HTR-10). Qualifying NEPHTIS is a vendor } \\
\text { specific activity. }\end{array}$ \\
\hline 4.2.2.1 & AREVA & $\begin{array}{l}\text { Additional benchmarks against } \\
\text { experimental data are required. Some } \\
\text { facilities that could provide valuable } \\
\text { data have been identified } \\
\text { (nonexhaustive): HTTR, HTR-10, and } \\
\text { Sandia Brayton Loop-30 kWe at Sandia } \\
\text { National Laboratory (SNL). }\end{array}$ & $\begin{array}{l}\text { Dedicated critical facilities for the NGNP will } \\
\text { not be constructed; validation of neutronic } \\
\text { codes will rely on data from critical facilities } \\
\text { that operated in the past and on existing } \\
\text { HTGR engineering scale reactors (HTTR and } \\
\text { HTR-10). Qualifying NEPHTIS is a vendor } \\
\text { specific activity. }\end{array}$ \\
\hline 4.2.2.2 & AREVA & $\begin{array}{l}\text { STAR-CD. Qualification of conduction } \\
\text { cooldown models on representative } \\
\text { geometry, materials, and temperature. } \\
\text { Qualification of countercurrent flow and } \\
\text { diffusion models. Qualification of } \\
\text { turbulence and stratification/mixing on } \\
\text { representative mockups in critical area. }\end{array}$ & $\begin{array}{l}\text { ANL NSTF experimental results will capture } \\
\text { key phenomena expected to be present in the } \\
\text { RCCS and provide data of sufficient } \\
\text { resolution for development and assessment of } \\
\text { applicable CFD (STAR-CD/Fluent) and } \\
\text { system codes (RELAP5-3D/ATHENA). }\end{array}$ \\
\hline $4.2 .2 .2 \mathrm{a}$ & AREVA & $\begin{array}{l}\text { Thermal-Hydraulics. Qualification of } \\
\text { STAR-CD for Modeling Conduction } \\
\text { Cooldown. }\end{array}$ & $\begin{array}{l}\text { ANL NSTF experimental results will capture } \\
\text { key phenomena expected to be present in the } \\
\text { RCCS and provide data of sufficient } \\
\text { resolution for development and assessment of } \\
\text { applicable CFD (STAR-CD/Fluent) and } \\
\text { system codes (RELAP5-3D/ATHENA). }\end{array}$ \\
\hline $4.2 .2 .2 \mathrm{~b}$ & AREVA & $\begin{array}{l}\text { Thermal-Hydraulics. Qualification of } \\
\text { STAR-CD for Modeling Diffusion, } \\
\text { Turbulence, etc. }\end{array}$ & $\begin{array}{l}\text { ANL NSTF experimental results will include } \\
\text { the identification of RCCS design candidates } \\
\text { from both the pebble-bed and prismatic } \\
\text { options. The range of thermal-hydraulic } \\
\text { conditions for normal operating and accident } \\
\text { events will be evaluated. An instrumentation } \\
\text { strategy will be developed to ensure that } \\
\text { adequately detailed velocity and turbulence } \\
\text { profiles are obtained. }\end{array}$ \\
\hline $4.2 .2 .2 \mathrm{c}$ & AREVA & $\begin{array}{l}\text { Thermal-Hydraulics. Qualification of } \\
\text { STAR-CD for Modeling Oxidation. }\end{array}$ & $\begin{array}{l}\text { The experimental V\&V and Graphite } \\
\text { programs will be providing data on oxidation } \\
\text { that can be used for code validation. }\end{array}$ \\
\hline 4.2.2.3 & AREVA & $\begin{array}{l}\text { Thermal-Hydraulics. Validation of } \\
\text { RELAP5-3D Consistent with that } \\
\text { Planned for MANTA. }\end{array}$ & $\begin{array}{l}\text { Validation of RELAP5 is part of the Methods } \\
\text { plan. Validation of MANTA is a vendor- } \\
\text { specific activity. }\end{array}$ \\
\hline $4.2 .3 .1 \mathrm{a}$ & AREVA & $\begin{array}{l}\text { Fuel. Qualification of ATLAS for } \\
\text { Modeling Irradiation of Coated Particles. }\end{array}$ & $\begin{array}{l}\text { The AGR Fuel Qualification Program } \\
\text { addresses Irradiation of coated particles. } \\
\text { Qualification of ATLAS is a vendor-specific } \\
\text { activity. }\end{array}$ \\
\hline $4.2 .3 .1 \mathrm{~b}$ & AREVA & $\begin{array}{l}\text { Fuel. Qualification of ATLAS for } \\
\text { Modeling Heat-up Experiment. }\end{array}$ & $\begin{array}{l}\text { The AGR Fuel Qualification Program } \\
\text { addresses heat-up experiments. Qualification } \\
\text { of ATLAS is a vendor-specific activity. }\end{array}$ \\
\hline
\end{tabular}


Table 20. (continued).

\begin{tabular}{|c|c|c|c|}
\hline Number & Vendor & Description & Status \\
\hline 4.2.4.1 & AREVA & $\begin{array}{l}\text { Experimental Work for Fission Product } \\
\text { Transport Model Qualification. }\end{array}$ & $\begin{array}{l}\text { The AGR Fuel Qualification Program } \\
\text { addresses the generation and transport of } \\
\text { fission products out of the fuel and block } \\
\text { matrix. }\end{array}$ \\
\hline С.07.04.03 & GA & $\begin{array}{l}\text { Core Corrosion Methods Validation } \\
\text { Data. }\end{array}$ & $\begin{array}{l}\text { The AGR Fuel Qualification Program } \\
\text { addresses the issue of corrosion of the fuel } \\
\text { matrix. }\end{array}$ \\
\hline C.11.03.19 & GA & $\begin{array}{l}\text { Graphite Corrosion Data for Methods } \\
\text { Validation. }\end{array}$ & $\begin{array}{l}\text { The AGC Graphite program addresses the } \\
\text { issues of graphite block corrosion. }\end{array}$ \\
\hline C.11.03.51 & GA & $\begin{array}{l}\text { Integral Nuclear Data Measurement at } \\
\text { Temperature for GT-MHR Physics } \\
\text { Methods Validation. }\end{array}$ & $\begin{array}{l}\text { Integral data is planned to be obtained from } \\
\text { HTTR, a question remains as to how } \\
\text { applicable this data is to current NGNP } \\
\text { designs. Fort St. Vrain may provide some } \\
\text { prismatic core validation data. }\end{array}$ \\
\hline C.11.03.52 & GA & $\begin{array}{l}\text { Critical Experimental Data for GT-MHR } \\
\text { Physics Methods Validation. }\end{array}$ & $\begin{array}{l}\text { New dedicated critical experiments are not } \\
\text { planned. The Methods program will be } \\
\text { relying on past critical experiments such as } \\
\text { Proteus, ASTRA, HTTR, and HTR-10. }\end{array}$ \\
\hline HTS-01-13 & WEC & $\begin{array}{l}\text { Despite the maturity of CFD as a design } \\
\text { tool, some model development is } \\
\text { required to use for compact heat } \\
\text { exchanger thermal performance } \\
\text { calculations. The models developed here } \\
\text { serve as an input to the structural } \\
\text { analysis model. }\end{array}$ & $\begin{array}{l}\text { Modeling of the process heat primary loop for } \\
\text { SG and IHX will be using RELAP5 and may } \\
\text { be coupled to ASPEN core and load } \\
\text { transients, the effective coupling of RELAP } \\
\text { and ASPEN will be an important challenge } \\
\text { for assessing performance. Data from this } \\
\text { modeling can also inform in-service } \\
\text { inspections and characterizing pressure } \\
\text { barriers. }\end{array}$ \\
\hline HTS-01-14 & WEC & $\begin{array}{l}\text { Data needed includes all information } \\
\text { required to validate the operational and } \\
\text { design basis of the compact heat } \\
\text { exchanger design selected, and all } \\
\text { information required to develop a } \\
\text { theoretical design basis for comparison } \\
\text { with empirical data. }\end{array}$ & $\begin{array}{l}\text { Modeling of the process heat primary loop for } \\
\text { SG and IHX will be using RELAP5 and may } \\
\text { be coupled to ASPEN core and load } \\
\text { transients, the effective coupling of RELAP } \\
\text { and ASPEN will be an important challenge } \\
\text { for assessing performance. Data from this } \\
\text { modeling can also inform in-service } \\
\text { inspections and characterizing pressure } \\
\text { barriers. }\end{array}$ \\
\hline HTS-01-16 & WEC & $\begin{array}{l}\text { Performance modeling methods are } \\
\text { required to characterize the steady-state } \\
\text { and transient performance of compact } \\
\text { heat exchangers. The required methods } \\
\text { are needed to support advancement of } \\
\text { the design, to provide inputs to thermal } \\
\text { and structural assessments. }\end{array}$ & $\begin{array}{l}\text { Modeling of the process heat primary loop for } \\
\text { SG and IHX will be using RELAP5 and may } \\
\text { be coupled to ASPEN core and load } \\
\text { transients, the effective coupling of RELAP } \\
\text { and ASPEN will be an important challenge } \\
\text { for assessing performance. Data from this } \\
\text { modeling can also inform in-service } \\
\text { inspections and characterizing pressure } \\
\text { barriers. }\end{array}$ \\
\hline
\end{tabular}

\subsubsection{Additional Technological Development}

No additional technological development tasks were identified. 


\subsubsection{Risk Analysis and PIRT}

Because the specific NGNP design has yet to be selected, a detailed PIRT cannot be completed. However, during the interim, first-cut PIRTs have been used instead as a guide for the initial R\&D work and planning for both prismatic and pebble-bed-type gas-cooled reactors as shown in Table 21 . 
Table 21. PIRT for normal operation and conduction cooldown scenarios.

\begin{tabular}{|c|c|c|c|}
\hline Phenomena & Component & Scenario & Status \\
\hline $\begin{array}{l}\text { Flow } \\
\text { distribution }\end{array}$ & $\begin{array}{l}\text { Upper Plenum } \\
\text { Core } \\
\text { Lower Plenum }\end{array}$ & $\begin{array}{l}\text { Normal Operation } \\
\text { Depressurized } \\
\text { Conduction Cooldown } \\
\text { (DCC) } \\
\text { Pressurized } \\
\text { Conduction Cooldown } \\
\text { (PCC) }\end{array}$ & $\begin{array}{l}\text { Section 4.1.2.3, Preliminary neutronics and CFD studies } \\
\text { have been initiated and validation data are sought from } \\
\text { core heat transfer experiments. It is necessary to know } \\
\text { the flow distribution for both operational and transient } \\
\text { conditions. }\end{array}$ \\
\hline Pressure drop & $\begin{array}{l}\text { Upper Plenum } \\
\text { Core }\end{array}$ & $\begin{array}{l}\text { Normal Operation } \\
\text { DCC } \\
\text { PCC }\end{array}$ & $\begin{array}{l}\text { Experiments on fluid dynamics of geometric transitions } \\
\text { conducted from FY } 2009 \text { through FY } 2011 \text { will employ } \\
\text { the INL matched-index-of-refraction flow system. } \\
\text { Measurements of turbulence distributions and pressure } \\
\text { drop (loss coefficients) are needed for CFD predictions } \\
\text { and design. }\end{array}$ \\
\hline $\begin{array}{l}\text { Mixing and } \\
\text { stratification }\end{array}$ & $\begin{array}{l}\text { Upper Plenum } \\
\text { Lower Plenum }\end{array}$ & $\begin{array}{l}\text { DCC } \\
\text { PCC }\end{array}$ & $\begin{array}{l}\text { The Frankfurt THAI facility supports experiments for } \\
\text { gas mixing phenomena and complex flow patterns } \\
\text { within multiple compartments. }\end{array}$ \\
\hline Hot plumes & Upper Plenum & $\begin{array}{l}\text { DCC } \\
\text { PCC }\end{array}$ & $\begin{array}{l}\text { An experiment is planned to investigate interactions } \\
\text { between hot plumes and parallel flow instabilities. The } \\
\text { envisioned experiment will produce a scaled fluid } \\
\text { behavior simulation of plumes moving upwards from } \\
\text { the hot core cooling channels of the natural circulation } \\
\text { development. }\end{array}$ \\
\hline $\begin{array}{l}\text { Thermal } \\
\text { resistance of } \\
\text { structures }\end{array}$ & $\begin{array}{l}\text { Upper Plenum } \\
\text { Lower Plenum }\end{array}$ & $\begin{array}{l}\text { DCC } \\
\text { PCC }\end{array}$ & $\begin{array}{l}\text { A high-level stochastic structure involving a } \\
\text { combination of materials modeling, thermal-hydraulics } \\
\text { R\&D, and manufacturing practice will need to be put in } \\
\text { place early. For the case of the prismatic reactor, small- } \\
\text { scale experiments encompassing both thermal- } \\
\text { hydraulics and materials phenomena will be performed } \\
\text { (some at INL and some at universities). }\end{array}$ \\
\hline $\begin{array}{l}\text { Reactivity } \\
\text { feedback } \\
\text { behavior }\end{array}$ & Core & Normal Operation & $\begin{array}{l}\text { JAEA has planned a spectrum of HTTR experiments } \\
\text { that include various reactivity transients and loss of } \\
\text { cooling conditions. Some of these tests have been } \\
\text { performed, still others are planned in } 2010 \text { through } \\
\text { 2012. JAEA has proposed a collaboration on HTGR } \\
\text { R\&D that would provide data to the NGNP Project for } \\
\text { the validation of codes. }\end{array}$ \\
\hline $\begin{array}{l}\text { Core } \\
\text { configuration } \\
\text { (bypass) }\end{array}$ & Core & $\begin{array}{l}\text { Normal Operation } \\
\text { DCC } \\
\text { PCC }\end{array}$ & $\begin{array}{l}\text { A series of experiments is envisioned that will test the } \\
\text { various theories regarding factors that influence the } \\
\text { quantity of bypass (in either the prismatic or PBR) as a } \\
\text { function of various factors, including manufacturing } \\
\text { tolerances and core configuration changes from } \\
\text { irradiation or thermal expansion. It is envisioned that } \\
\text { the work scope will be a DOE laboratory-university } \\
\text { partnership. }\end{array}$ \\
\hline Heat transfer & Core & $\begin{array}{l}\text { Normal Operation } \\
\text { DCC } \\
\text { PCC }\end{array}$ & $\begin{array}{l}\text { Preliminary neutronics and CFD studies have been } \\
\text { initiated and validation data are sought from core heat } \\
\text { transfer experiments. Under low-flow conditions such } \\
\text { as can occur after the primary blowers have tripped, } \\
\text { conduction, radiation, and buoyancy-driven flow } \\
\text { becomes the dominant heat transfer mechanisms. }\end{array}$ \\
\hline
\end{tabular}


Table 21. (continued).

\begin{tabular}{|c|c|c|c|}
\hline Phenomena & Component & Scenario & Status \\
\hline $\begin{array}{l}\text { Power } \\
\text { distribution }\end{array}$ & Core & $\begin{array}{l}\text { Normal Operation } \\
\text { DCC } \\
\text { PCC }\end{array}$ & $\begin{array}{l}\text { Integral experiments, including power distribution, are } \\
\text { planned to be studied using the HTTF. The HTTF will } \\
\text { be operational for startup testing in FY } 2012 \text { and the } \\
\text { formal prismatic test program will begin in FY } 2013 \text {. }\end{array}$ \\
\hline $\begin{array}{l}\text { Axial heat } \\
\text { conduction } \\
\text { and radiation }\end{array}$ & Core & $\begin{array}{l}\text { DCC } \\
\text { PCC }\end{array}$ & $\begin{array}{l}\text { For the prismatic HTGR, more sophisticated thermal } \\
\text { fluid codes must model the radial and axial flow } \\
\text { between the blocks to get a firmer picture of the } \\
\text { temperature distribution within the fuel and core. For } \\
\text { Pebble bed, 2-D or 3-D thermal fluid codes model the } \\
\text { bed as a porous medium with known pressure drop and } \\
\text { heat transfer correlations for pebble beds. Coolant flow } \\
\text { can be in any direction, but analyses indicate that the } \\
\text { axial flow assumption is a reasonable to first order. }\end{array}$ \\
\hline $\begin{array}{l}\text { Natural } \\
\text { circulation in } \\
\text { the RPV }\end{array}$ & Core & $\begin{array}{l}\text { DCC } \\
\text { PCC }\end{array}$ & $\begin{array}{l}\text { An experiment is planned to investigate interactions } \\
\text { between hot plumes and parallel flow instabilities. The } \\
\text { envisioned experiment will produce a scaled fluid } \\
\text { behavior simulation of plumes moving upwards from } \\
\text { the hot core cooling channels of the natural circulation } \\
\text { development in the upper plenum and of the downward } \\
\text { movement of upper plenum inventory into the cooler } \\
\text { channels in route to the lower plenum. }\end{array}$ \\
\hline $\begin{array}{l}\text { Air and water } \\
\text { ingress }\end{array}$ & $\begin{array}{l}\text { Core } \\
\text { Lower Plenum }\end{array}$ & DCC & $\begin{array}{l}\text { The highest-priority Methods activities for FY } 2011 \\
\text { through } 2013 \text { will include: conducting integral } \\
\text { experiments in the HTTF, completing and operating the } \\
\text { Natural Circulation Shutdown Test Facility for } \\
\text { investigating ex-core heat removal and performing } \\
\text { bypass and air ingress experiments with associated CFD } \\
\text { model validation. }\end{array}$ \\
\hline $\begin{array}{l}\text { Potential } \\
\text { fission product } \\
\text { transport }\end{array}$ & Core & DCC & $\begin{array}{l}\text { The AGR Fuel Qualification Program addresses the } \\
\text { generation and transport of fission products out of the } \\
\text { fuel and block matrix into the primary circuit. }\end{array}$ \\
\hline Decay heat & Core & $\begin{array}{l}\text { DCC } \\
\text { PCC }\end{array}$ & $\begin{array}{l}\text { With the use of the ANL NSTF it may be possible to } \\
\text { perform depressurized conduction cooldown } \\
\text { experiments in the NSTF for the prismatic block reactor } \\
\text { to simulate the conduction and radiation of the decay } \\
\text { heat away from the fuel in the core and transfer it to the } \\
\text { primary vessel metal. }\end{array}$ \\
\hline $\begin{array}{l}\text { Material } \\
\text { properties }\end{array}$ & Core & $\begin{array}{l}\text { DCC } \\
\text { PCC }\end{array}$ & $\begin{array}{l}\text { For the case of the prismatic reactor, small-scale } \\
\text { experiments encompassing both thermal-hydraulics and } \\
\text { materials phenomena will be performed (some at INL } \\
\text { and some at universities. The R\&D effort for the PBR } \\
\text { will be planned to complement available data already } \\
\text { recorded during extensive experimental programs at the } \\
\text { African Pebble Bed Modular Reactor, Pty. }\end{array}$ \\
\hline
\end{tabular}


Table 21. (continued).

\begin{tabular}{|c|c|c|c|}
\hline Phenomena & Component & Scenario & Status \\
\hline $\begin{array}{l}\text { Heat transfer } \\
\text { at operational } \\
\text { conditions }\end{array}$ & $\begin{array}{l}\text { RCCS } \\
\text { Lower Plenum }\end{array}$ & Normal Operation & $\begin{array}{l}\text { The HTTF will be operational for startup testing in } \\
\text { FY } 2012 \text { and the formal prismatic test program will } \\
\text { begin in FY 2013. It is anticipated that the HTTF will } \\
\text { generate data for several years and the experimental test } \\
\text { matrix will be tailored to match the experiments } \\
\text { scheduled for inclusion in all of the other experimental } \\
\text { facilities, including the RCCS, plenum experiments, } \\
\text { core heat transfer experiments, air ingress experiments, } \\
\text { and bypass flow experiments. }\end{array}$ \\
\hline $\begin{array}{l}\text { Natural } \\
\text { circulation in } \\
\text { cavity }\end{array}$ & RCCS & Normal Operation & $\begin{array}{l}\text { The NSTF will be used to acquire the model/code } \\
\text { validation data for natural convection and radiation heat } \\
\text { transfer in the reactor cavity and the RCCS. }\end{array}$ \\
\hline $\begin{array}{l}\text { Laminar } \\
\text { turbulent } \\
\text { transition flow }\end{array}$ & RCCS & $\begin{array}{l}\text { DCC } \\
\text { PCC }\end{array}$ & $\begin{array}{l}\text { Preliminary neutronics and CFD studies have been } \\
\text { initiated and validation data are sought from core heat } \\
\text { transfer experiments. Under low-flow conditions such } \\
\text { as can occur after the primary blowers have tripped, } \\
\text { conduction, radiation, and buoyancy-driven flow } \\
\text { becomes the dominant heat transfer mechanisms. This } \\
\text { flow can be a mixture of turbulent and laminar flow and } \\
\text { thus may be subject to considerable instability. }\end{array}$ \\
\hline $\begin{array}{l}\text { Forced-natural } \\
\text { mixed } \\
\text { convection } \\
\text { flow }\end{array}$ & RCCS & $\begin{array}{l}\text { DCC } \\
\text { PCC }\end{array}$ & $\begin{array}{l}\text { A potential experiment has been designed to investigate } \\
\text { core heat transfer. The experiment will support the } \\
\text { efforts of the current computational task concerning the } \\
\text { hot channel issue by providing benchmark data for } \\
\text { detailed assessment of its turbulence models for forced } \\
\text { and mixed convection with helium property variation. }\end{array}$ \\
\hline $\begin{array}{l}\text { Heat } \\
\text { transfer- } \\
\text { radiation and } \\
\text { convection in } \\
\text { duct }\end{array}$ & RCCS & $\begin{array}{l}\text { DCC } \\
\text { PCC }\end{array}$ & $\begin{array}{l}\text { The HTTF will be operational for startup testing in } \\
\text { FY } 2012 \text { and the formal prismatic test program will } \\
\text { begin in FY 2013. It is anticipated that the HTTF will } \\
\text { generate data for several years and the experimental test } \\
\text { matrix will be tailored to match the experiments } \\
\text { scheduled for inclusion in all of the other experimental } \\
\text { facilities, including the RCCS, plenum experiments, } \\
\text { core heat transfer experiments, air ingress experiments, } \\
\text { and bypass flow experiments. }\end{array}$ \\
\hline $\begin{array}{l}\text { Thermal } \\
\text { striping }\end{array}$ & Lower Plenum & Normal Operation & No reference to thermal striping. \\
\hline Jet behavior & Lower Plenum & Normal Operation & $\begin{array}{l}\text { In typical prismatic HTGR concepts, the complicated } \\
\text { transition from coolant channels to the lower plenum } \\
\text { provides the inlet conditions for the jets into the lower } \\
\text { plenum. Measurements of turbulence distributions and } \\
\text { pressure drop (loss coefficients) are needed for CFD } \\
\text { predictions and design. Depending on the reactor } \\
\text { designs, comparable problems may appear for the upper } \\
\text { plenum. }\end{array}$ \\
\hline
\end{tabular}

\subsubsection{Technology Development Roadmap}

A TDRM for NGNP R\&D Methods is shown in Appendix A. 


\subsubsection{Section Summary}

All of the Methods DDNs are addressed within the Methods program. There are no risks identified or associated with the Methods program. There is one PIRT associated with 'Thermal Striping' that is not being addressed by the program. This is a phenomena associated with reactor design and is therefore not part of the Methods program. 


\subsection{Nuclear Energy Research Initiative and Nuclear Energy University Program}

A number of external initiatives identified throughout the NGNP R\&D test programs complement the work being performed by INL on NGNP. Table 22 identifies the areas being worked under NERI and NEUP.

Table 22. Areas being worked under NERI and NEUP.

\begin{tabular}{|c|c|c|}
\hline R\&D Systems & Task & Description of Initiative \\
\hline Fuels & $\begin{array}{l}\text { Fuel performance } \\
\text { modeling. }\end{array}$ & $\begin{array}{l}\text { NERI - Some aspects of this work are being addressed in } \\
\text { DOE Nuclear Energy Research Initiative (NERI) and } \\
\text { International Nuclear Energy Research Initiative projects } \\
\text { (I-NERI) with France and a joint Japan-ORNL I-NERI. }\end{array}$ \\
\hline Fuels & $\begin{array}{l}\text { Code Benchmarking and } \\
\text { Improvement. }\end{array}$ & $\begin{array}{l}\text { NERI - The performance test fuel and fuel qualification } \\
\text { irradiations and accident testing, along with planned } \\
\text { material property irradiations obtained via NERI and } \\
\text { international collaborations will provide much of the } \\
\text { separate effects data needed to improve the fuel } \\
\text { performance models. }\end{array}$ \\
\hline RPV & Emissivity. & $\begin{array}{l}\text { NERI - There is a project at the University of Wisconsin- } \\
\text { Madison that is addressing emissivity of candidate RPV } \\
\text { core internal materials. Emissivity is being determined as a } \\
\text { function of the time and temperature of exposure to impure } \\
\text { helium and air. These experiments address materials } \\
\text { behavior on the interior and exterior surface of the reactor } \\
\text { system. }\end{array}$ \\
\hline IHX & Environment. & $\begin{array}{l}\text { NERI - The University of Michigan has completed work to } \\
\text { define strategies for the improvement of high temperature } \\
\text { alloys for structural components, such as the NGNP IHX } \\
\text { operating at } 1000^{\circ} \mathrm{C} \text { in helium. They investigated the } \\
\text { oxidation/carburization behavior and microstructure } \\
\text { stability and how these processes affect creep in order to } \\
\text { develop a fundamental understanding of how impurities in } \\
\text { the helium environment affect these degradation processes. }\end{array}$ \\
\hline IHX & $\begin{array}{l}\text { Diffusional Creep for } \\
\text { Alloy } 617 .\end{array}$ & $\begin{array}{l}\text { NEUP - A portion of the work necessary to accomplish this } \\
\text { task is underway at the University of Cincinnati with NEUP } \\
\text { support. }\end{array}$ \\
\hline $\mathrm{SG}$ & $\begin{array}{l}\text { Diffusional Creep } \\
\text { Mechanism for Alloy } \\
800 \mathrm{H} \text {. }\end{array}$ & $\begin{array}{l}\text { NEUP - A portion of this work is underway at University of } \\
\text { Cincinnati with NEUP support. }\end{array}$ \\
\hline Graphite & Microscale modeling. & $\begin{array}{l}\text { NERI - It is assumed that the primary funding source for } \\
\text { microscale modeling will be NERI type awards. }\end{array}$ \\
\hline Graphite & Emissivity. & $\begin{array}{l}\text { NEUP - Initial emissivity values for graphite have begun } \\
\text { through the DOE's NEUP on graphite types of current } \\
\text { interest. }\end{array}$ \\
\hline Methods & $\begin{array}{l}\text { Validate and develop } \\
\text { software. }\end{array}$ & $\begin{array}{l}\text { NERI - The intention is to use I-NERIs as medium for } \\
\text { international relationships and collaboration projects to } \\
\text { validate and develop software. }\end{array}$ \\
\hline
\end{tabular}




\section{CONCLUSIONS}

\section{Conclusions}

Conclusions from the Technology Readiness Assessment and the creation of TDRMs for the R\&D program development plans are as follows:

- The current technology development test plans for the NGNP R\&D programs apply to critical ${ }^{\mathrm{d}}$ reactor components that require broad and fundamental $R \& D$. As the design matures further analysis is required to identify any additional components that may be on the critical path

- Until the NGNP reactor design is more mature and critical decision down-selects have been made, then some key reactor components cannot be sufficiently advanced, resulting in increased risk being carried forward on the project and possible delays to the schedule

- As the reactor outlet temperature increases to $850^{\circ} \mathrm{C}$ (and above), the number of reactor components required to be made from ceramic composites increases significantly. During a conduction cooldown scenario, the decay heat is too high for metallic materials, possibly requiring the replacement of reactor components. No INL ceramic composite R\&D program exists to advance the development, codification, and licensing of ceramic components.

- All of the INL NGNP R\&D technology program plans are actively engaged in advancing the technology for the NGNP reactor components. Their focus is on ASME BPV codification, NRC licensing, satisfying DDNs, and addressing items of risk and PIRTs. ${ }^{e}$ There are no INL NGNP R\&D activities being pursued that are not directed at support of NGNP deployment.

d. The use of the word critical in this document refers to being on the critical path for reactor deployment, not crucial to or related to nuclear safety.

e. Any omission or exceptions are identified in the main body of this document. 


\section{REFERENCES}

1. PLN-2804, "Next Generation Nuclear Plant Steam Generator and Intermediate Heat Exchanger Materials Research and Development Plan," Revision 1, Idaho National Laboratory, 09/23/2010.

2. PLN-2803, "Next Generation Nuclear Plant Reactor Pressure Vessel R\&D Test Plan," Revision 1, Idaho National Laboratory, 07/14/2010.

3. PLN-3305, "Next Generation Nuclear Plant Heat Transport system Components Engineering Test Plan" Revision 1, Idaho National Laboratory, 06/30/2010.

4. PLN-3479, "Next Generation Nuclear Plant R\&D Test Control Plan - High Temperature Hydrogen Permeation through Nickel alloys," Revision 1, Idaho National Laboratory, 04/19/2010.

5. PLN-2498, "Next Generation Nuclear Plant Methods Technical Plan Revision 2, Idaho National Laboratory," 09/27/2010.

6. PLN-3604, "Next Generation Nuclear Plant High Temperature Steam Electrolysis Technical Program Plan," Revision 0, Idaho National Laboratory, 03/04/2011.

7. INL/EXT-10-19125, "Next Generation Nuclear Plant High Temperature Steam Electrolysis Test Plans," Revision 0, Idaho National Laboratory, 06/16/2010.

8. PLN-2497, "Next Generation Nuclear Plant Graphite Technology Development Plan," Revision 1, Idaho National Laboratory, 10/04/2010.

9. PLN-3636, "Technical Program Plan for The Next Generation Nuclear Plan/Advanced Gas Reactor Fuel Development and qualification Program," Revision 0, Idaho National Laboratory, 09/30/2010.

10. NGNP-R00016, "General Atomics - Conceptual Design Report -Steam Cycle Modular Helium Reactor (SC-MHR) Demonstration Plant," Revision 0, 23/12/2010.

11. ORNL/TM-2009/185 - "Composite Technology Development Plan,” Rev 3, June 2010.

12. INL/EXT-09-16598, "Next Generation Nuclear Plant Project Technology Development Roadmaps: The Technical Path Forward for $750-800^{\circ} \mathrm{C}$ Reactor Outlet Temperature," Revision 0, August 2009.

13. General Atomics "Effect of Reactor Outlet Helium Temperature on the Need for Composites in the NGNP," 911175, Revision 0, 11/6/2009.

14. INL/EXT-11-21097 'HTGR Dust Safety Issues and Needs for R\&D’ - Rev 0, 6/27/2011.

15. NGNP-CDWP TI-DDN ‘Design Data Needs (DDNs) Reconciliation against PIRTS' Revision 1, April 2009.

16. PC-000570 'Reconciliation of NGNP DDNs with NRC PIRTS', Revision 0, 09/19/2008.

17. 12-9102279-001 'NGNP Conceptual Design DDN/PIRT Reconciliation', Revision 0, 9/30/2008. 
Appendix A

\section{Technology Development Roadmaps}




\section{Appendix A-Technology Development Roadmaps}

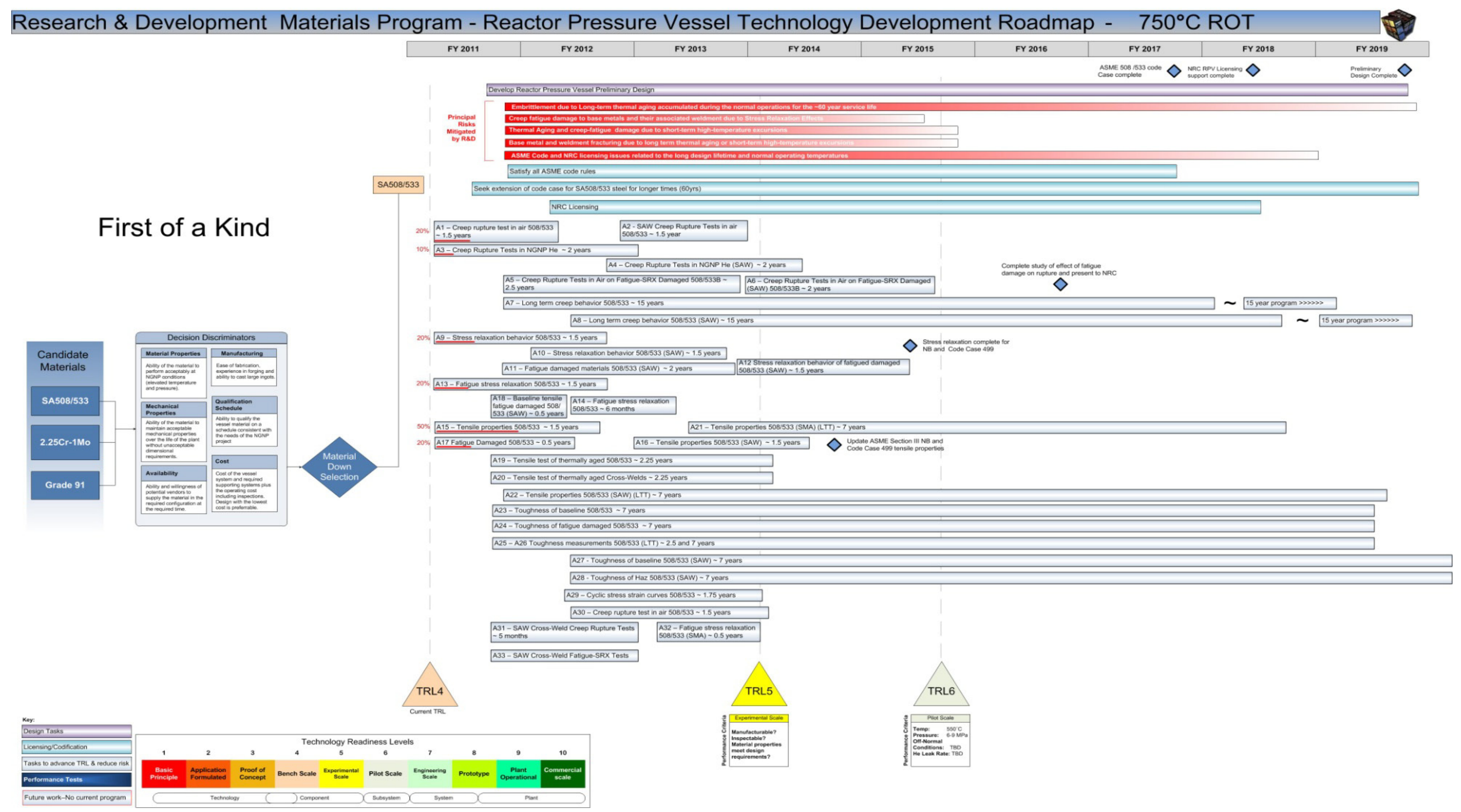


Research \& Development Materials Program - Reactor Pressure Vessel Technology Development Roadmap - $950^{\circ} \mathrm{C}$ ROT

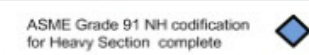

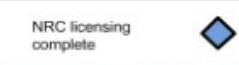

\section{Nth of a Kind}

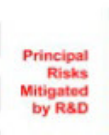

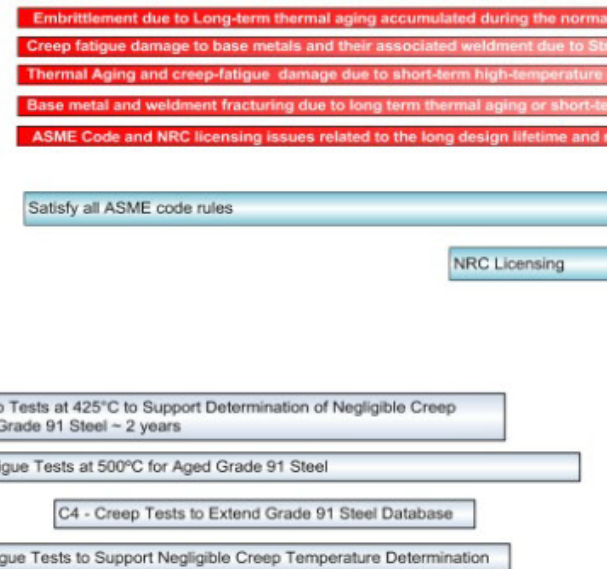

Nh of a Kind

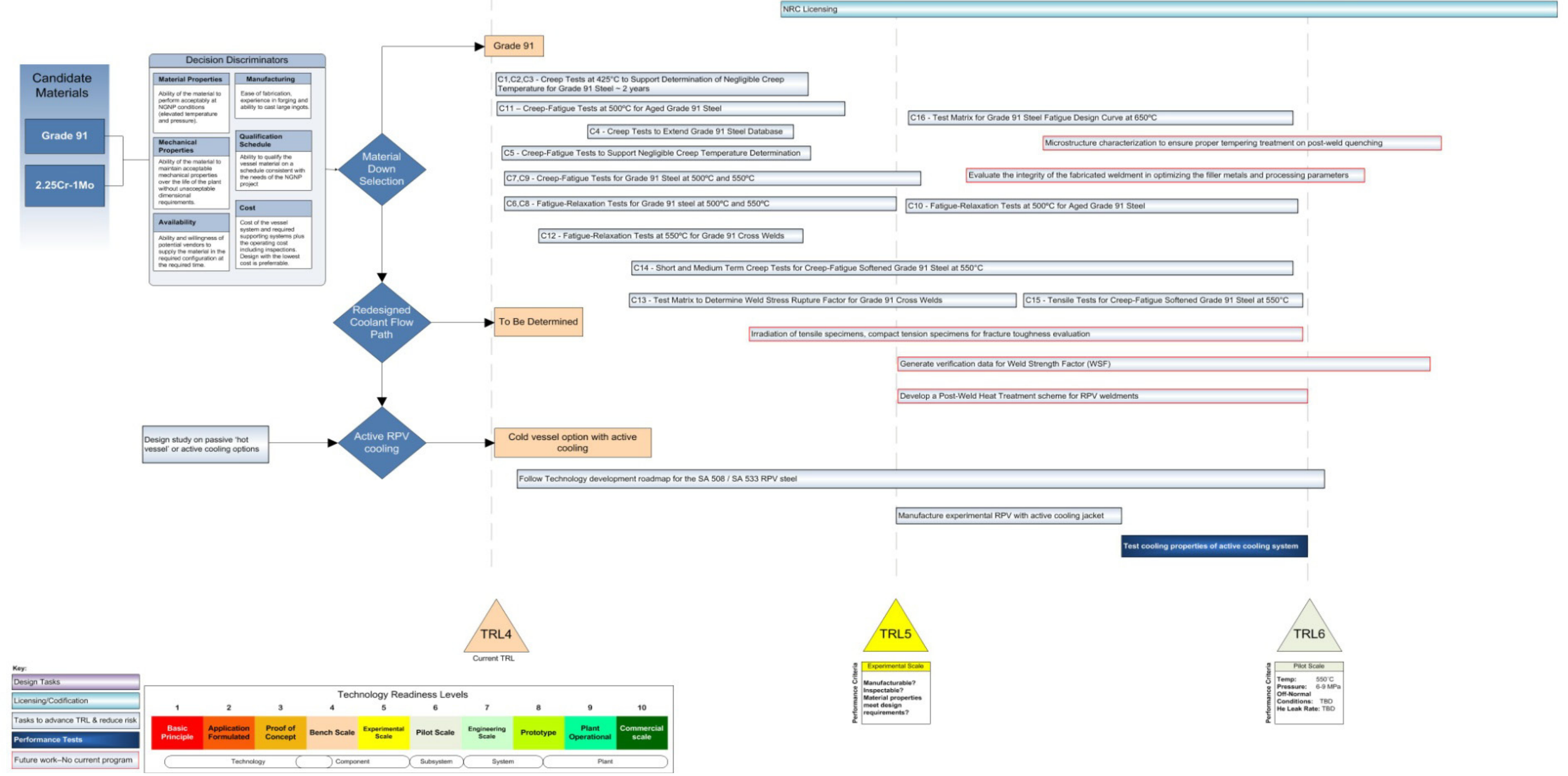

Figure A-2. R\&D Materials Program reactor pressure vessel (NOAK). 

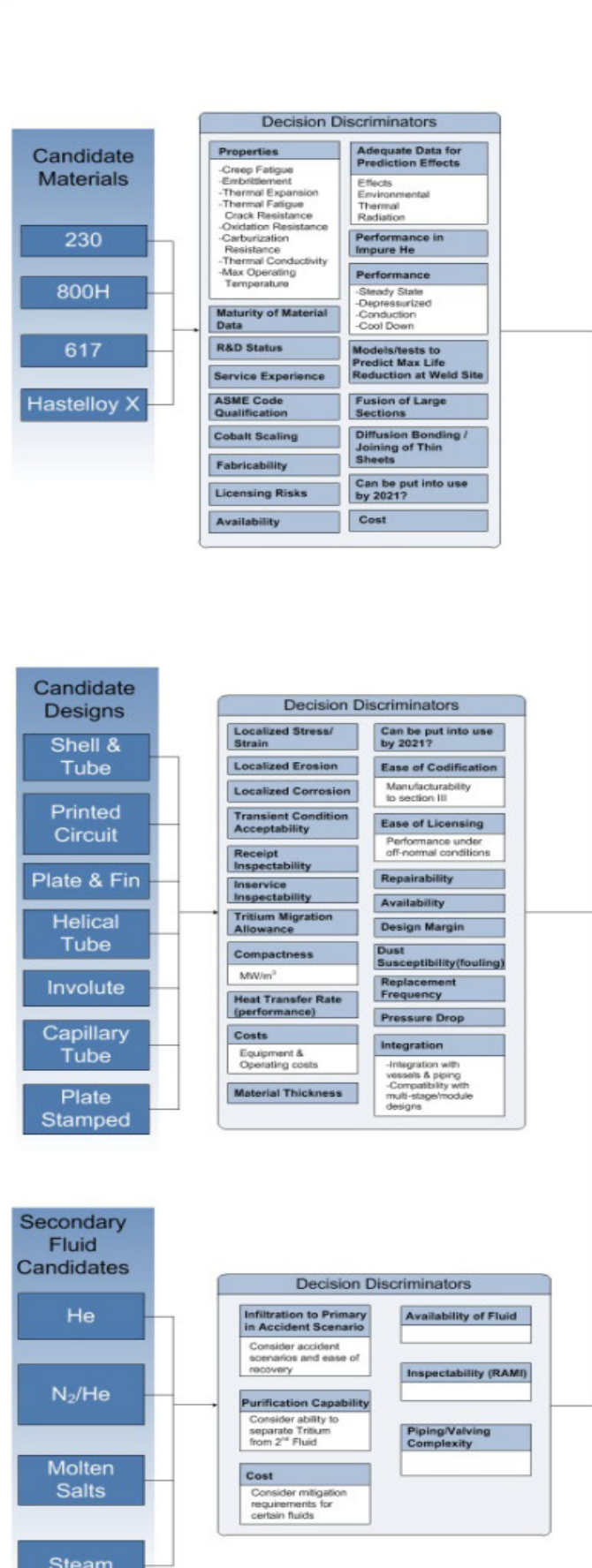

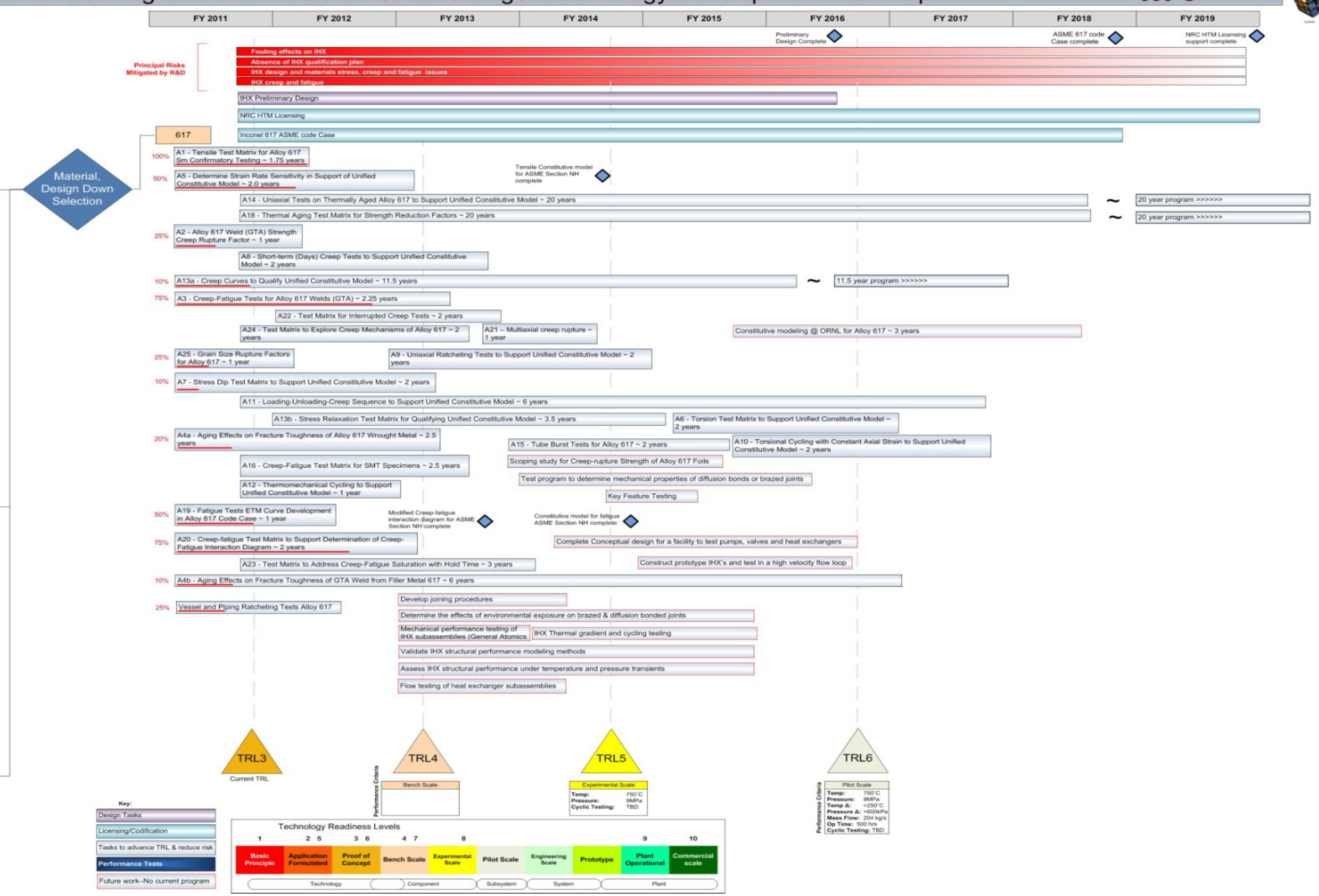

Figure A-3. R\&D Materials Program intermediate heat exchanger (NOAK). 

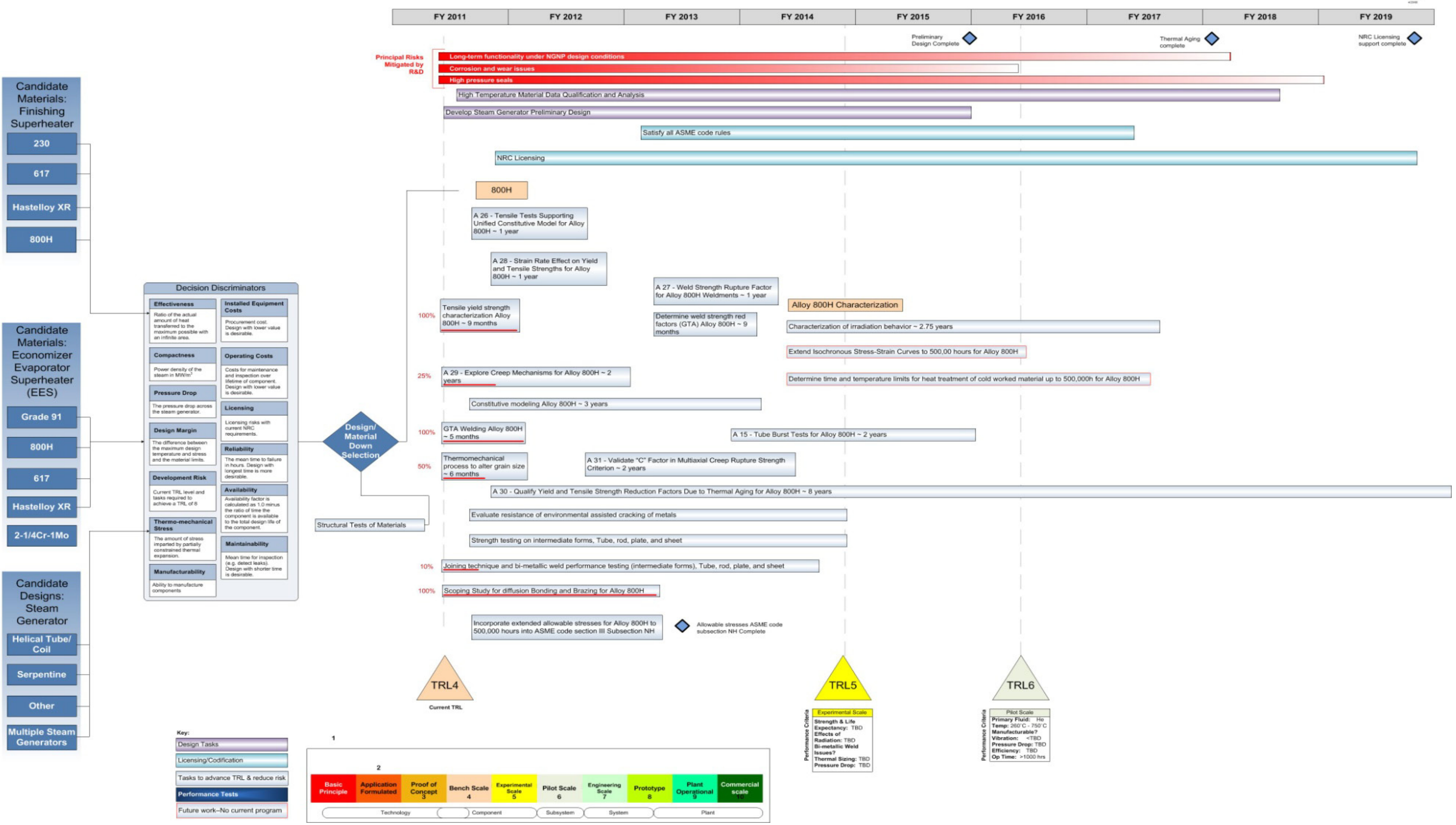

Figure A-4. R\&D Materials Program steam generator (FOAK). 


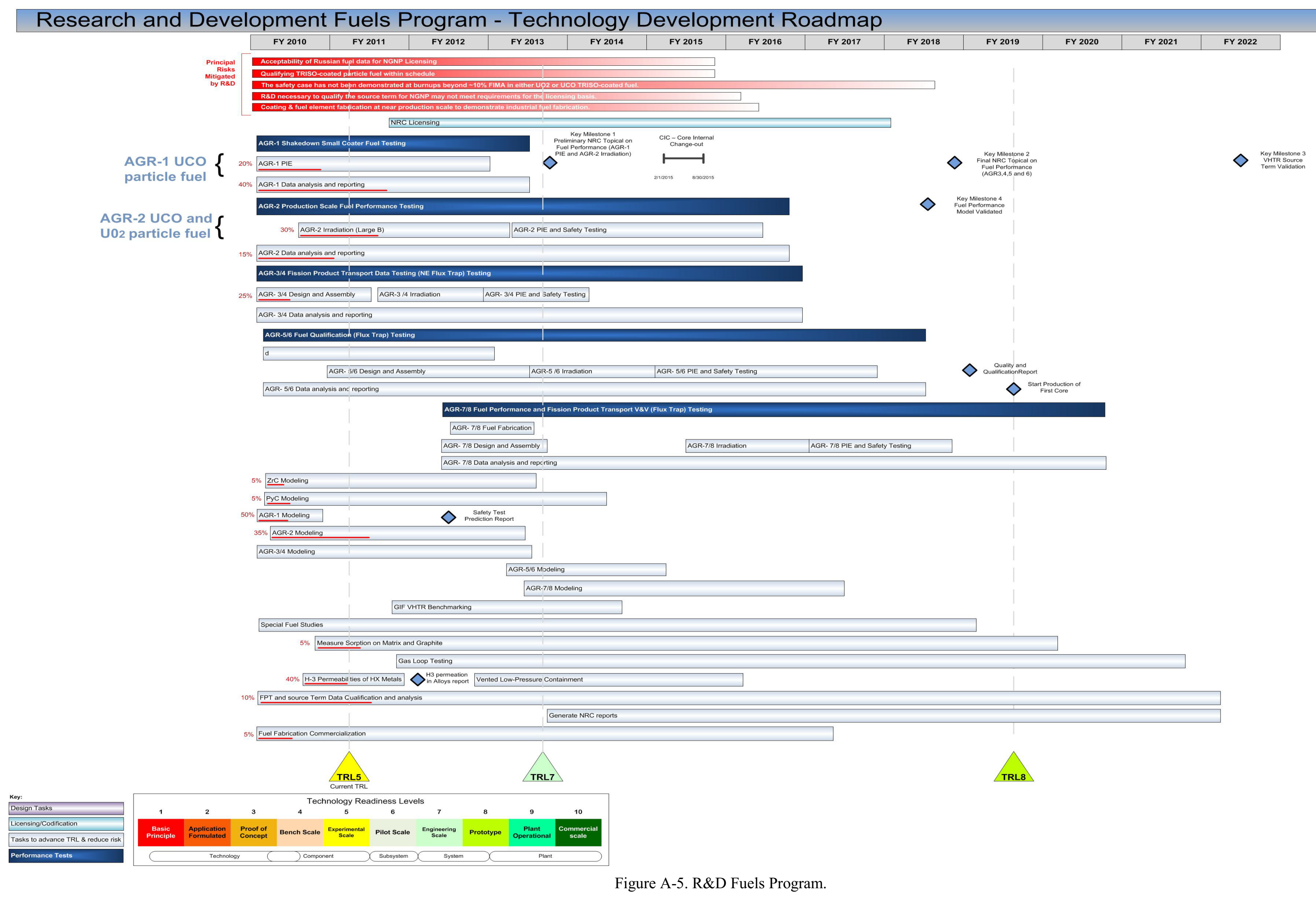




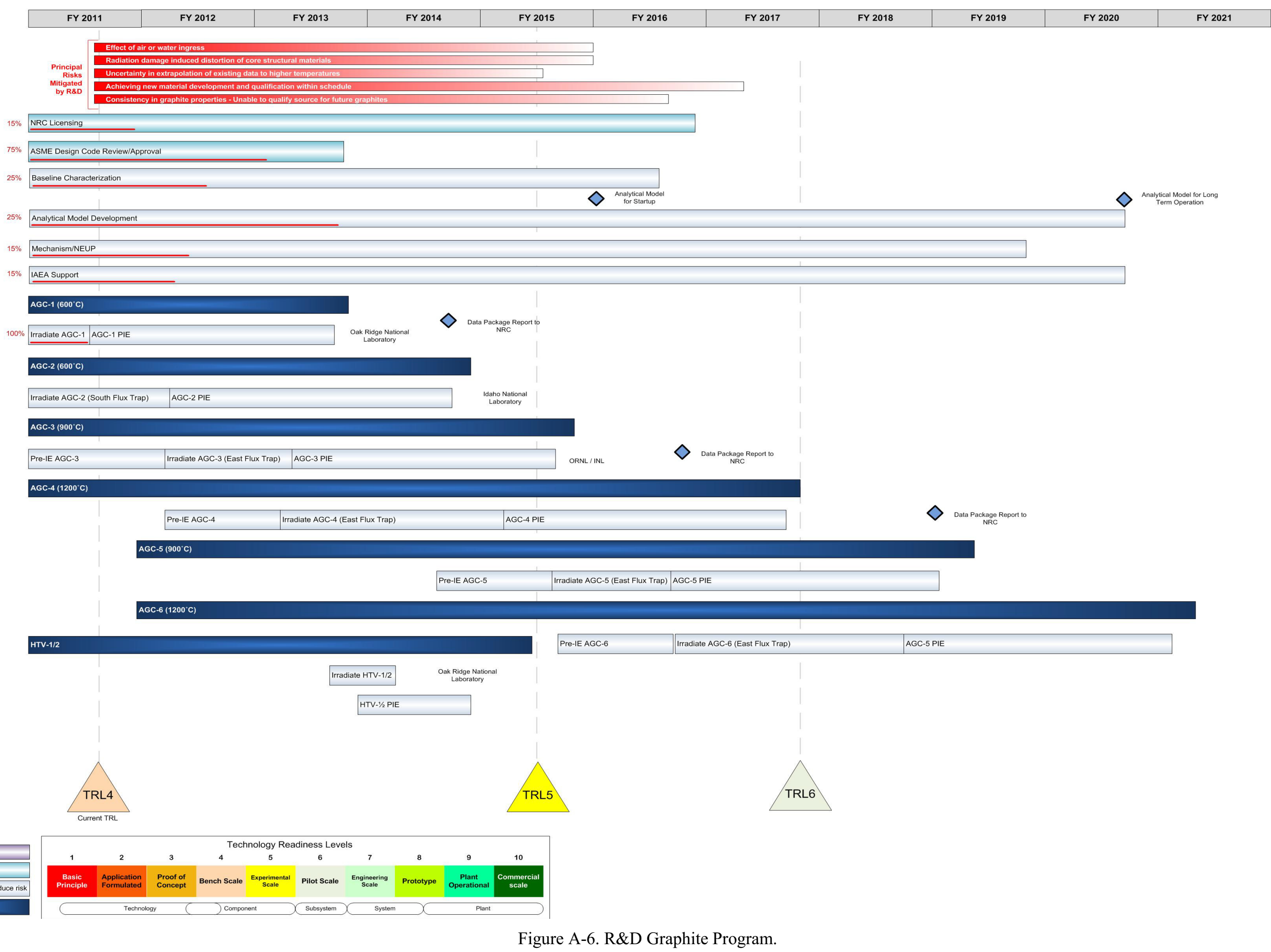




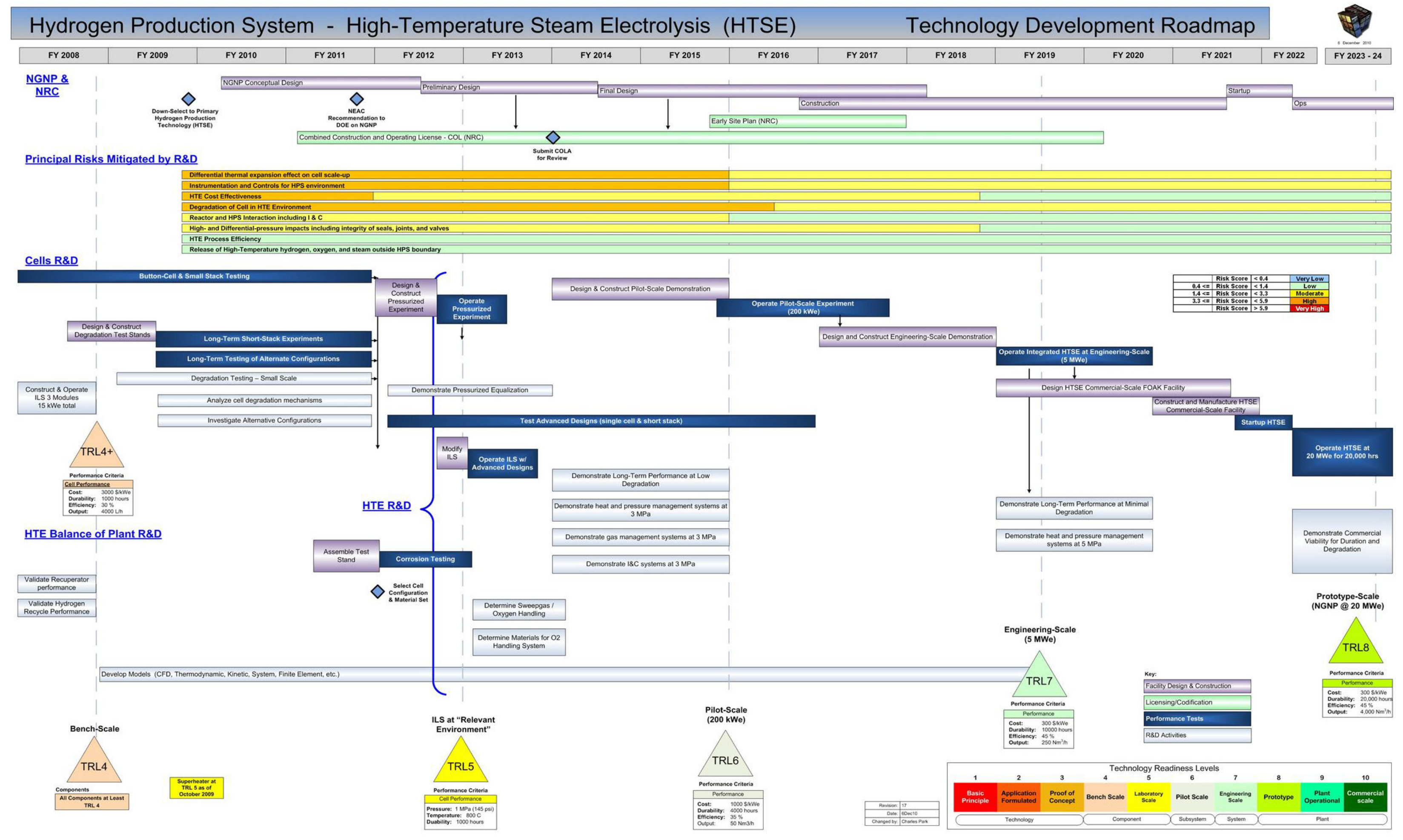

Figure A-7. R\&D HTSE Program. 
Research and Development Methods Program - Technology Development Roadmap

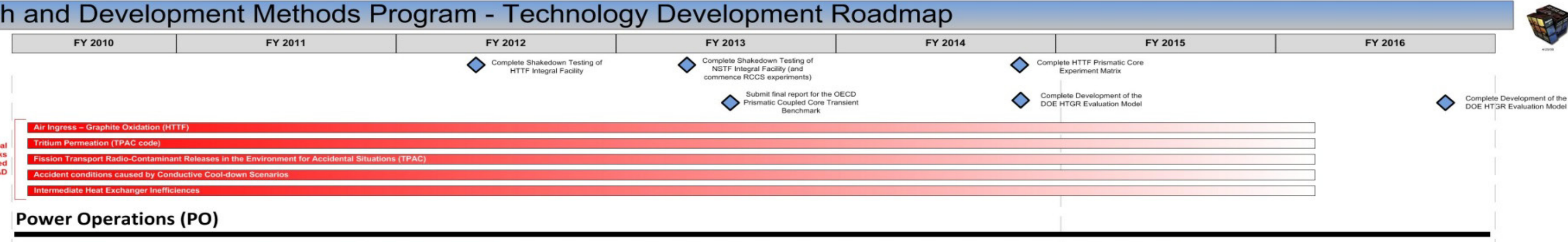

\section{Power Operations (PO)}

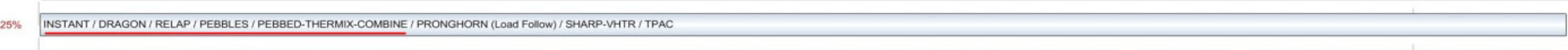

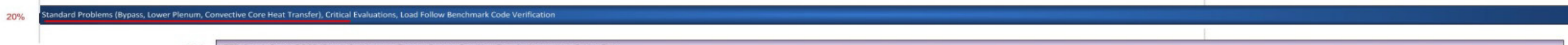

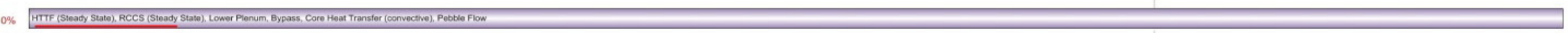

Anticipated Operating Occurrences (AOOs)

$15 \%$ PRonctoren (PLLFC)

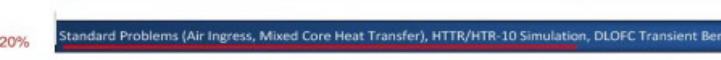

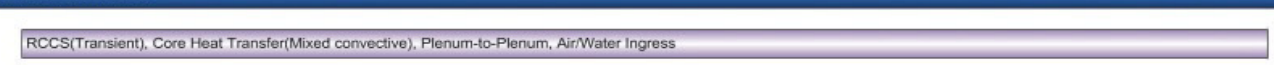

\section{Design Basis Accidents (DBAs)}

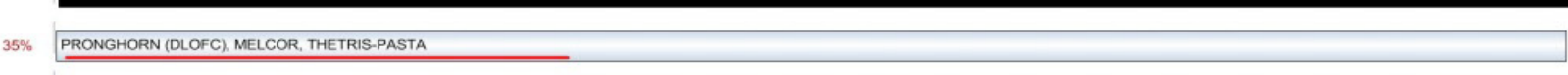

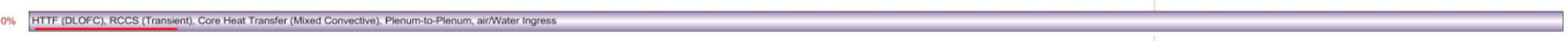

Beyond Design Basis Accidents (BDBA)

35\% Pronctoren (OLOFC)

TRL4

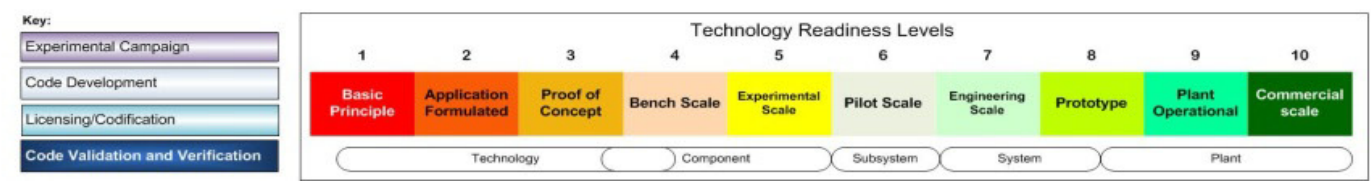

Figure A-8. R\&D Methods Program. 